\title{
MÉTODOS ALTERNATIVOS DE PRODUÇÃO DE MUDAS CÍTRICAS EM RECIPIENTES NA PREVENÇÃO DA MORTE SÚBITA DOS CITROS
}

\author{
EDUARDO AUGUSTO GIRARDI
}

\author{
Dissertação apresentada à Escola Superior \\ de Agricultura "Luiz de Queiroz", \\ Universidade de São Paulo, para obtenção \\ do título de Mestre em Agronomia, Área \\ de Concentração: Fitotecnia.
}

P I R A C I C A B A

Estado de São Paulo - Brasil

Março - 2005 


\title{
MÉTODOS ALTERNATIVOS DE PRODUÇÃO DE MUDAS CÍTRICAS EM RECIPIENTES NA PREVENÇÃO DA MORTE SÚBITA DOS CITROS
}

\author{
EDUARDO AUGUSTO GIRARDI
}

Engenheiro Agrônomo

Orientador: Prof. Dr. FRANCISCO DE ASSIS ALVES MOURÃO FILHO

Dissertação apresentada à Escola Superior

de Agricultura "Luiz de Queiroz", Universidade de São Paulo, para obtenção do título de Mestre em Agronomia, Área de Concentração: Fitotecnia.

P I R A C I C A B A

Estado de São Paulo - Brasil

Março - 2005 
Dados Internacionais de Catalogação na Publicação (CIP) DIVISÃO DE BIBLIOTECA E DOCUMENTAÇÃO - ESALQ/USP

\section{Girardi, Eduardo Augusto}

Métodos alternativos de produção de mudas cítricas em recipientes na prevenção da morte súbita dos citros / Eduardo Augusto Girardi. - - Piracicaba, 2005.

$73 \mathrm{p}$.

Dissertação (mestrado) - - Escola Superior de Agricultura Luiz de Queiroz, 2005. Bibliografia.

1. Citricultura 2. Cultivo protegido 3. Morte súbita dos citros 4. Mudas - Produção 5. Porta-enxertos I. Título

CDD 634.3

"Permitida a cópia total ou parcial deste documento, desde que citada a fonte - O autor" 
Aos meus pais, Cláudio e Ana Regina,

por tudo o que significam para mim,

DEDICO.

A meus avós

e a minha namorada Raquel

pelo amor de todas as horas,

OFEREÇO. 


\section{AGRADECIMENTOS}

A Deus, pela força concedida em todos os momentos, tornando possível a conclusão deste trabalho;

Ao Prof. Dr. Francisco de Assis Alves Mourão Filho, pela preciosa amizade, orientação, pela confiança, dedicação e incentivo;

Aos Engenheiros Agrônomos Gilberto Tozzati e Reinaldo Donizete Corte, da empresa Sanicitrus Mudas Cítricas, pela gentileza de permitir a condução dos trabalhos nas dependências de sua empresa, pela doação de material vegetal e de consumo para montagem dos experimentos e pela atenção dada;

Aos pesquisadores Dr. Jorgino Pompeu Jr., do Centro APTA Citros "Sylvio Moreira” e Dr. Eduardo Sanches Stuchi, da EMBRAPA Mandioca e Fruticultura, pela doação das sementes usadas neste trabalho e pelas sugestões;

À Fundação de Amparo a Pesquisa do Estado de São Paulo (FAPESP), pela concessão da bolsa de mestrado, destinada à realização deste trabalho;

A todos os funcionários da Sanicitrus Mudas Cítricas, pela ajuda e boa-vontade na condução dos experimentos de campo;

A todos os professores e funcionários do Setor de Horticultura da USP-ESALQ, pelo companheirismo e amizade;

À República Vak Tôa, pelos anos de convivência e alegria e aos meus colegas Alessandro, Gustavo e Leonardo, pelos bons momentos juntos;

A todos os meus amigos e colegas de Pós-Graduação do Setor de Horticultura da USP-ESALQ, pelo convívio, amizade e respeito;

Obrigado. 


\section{SUMÁRIO}

Página

LISTA DE TABELAS................................................................................... viii

LISTA DE FIGURAS...................................................................................... xi

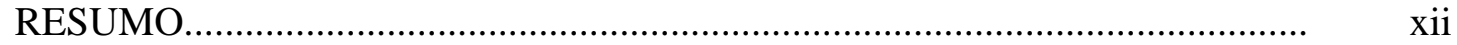

SUMMARY .................................................................................................. xiv

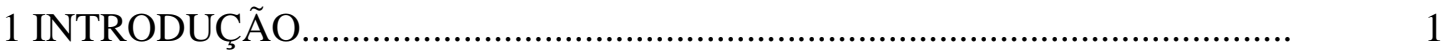

2 REVISÃO DE LITERATURA.................................................................. 4

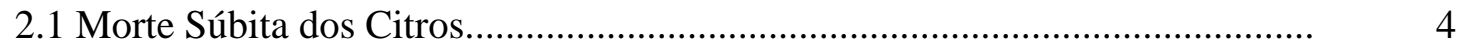

2.2 Emprego de subenxertia em citricultura........................................................ 5

2.3 Emprego da estaquia em citricultura.................................................................

2.4 Emprego de interenxertia em citricultura....................................................... 9

2.5 Sistema comercial de produção de mudas cítricas no Estado de São Paulo.... 12

3 MATERIAL E MÉTODOS......................................................................... 15

3.1 Desenvolvimento de onze porta-enxertos em diferentes recipientes para fins de subenxertia................................................................................... 15

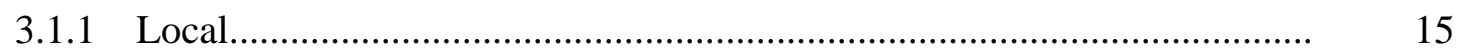

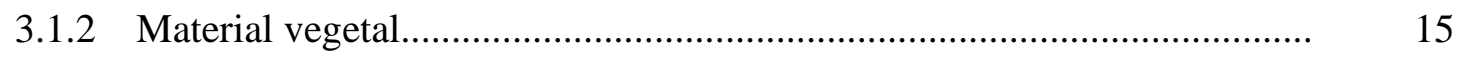

3.1.3 Coleta de sementes e semeadura................................................................ 16

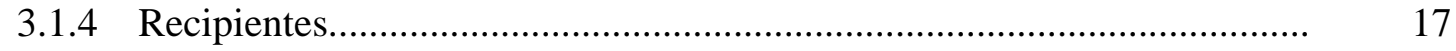

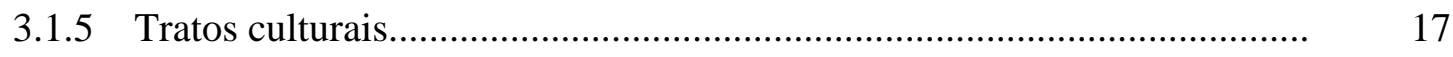

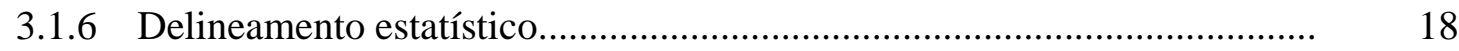

3.1.7 Dados biométricos coletados................................................................... 19 
3.2 Produção de mudas de laranja 'Pêra’ (Citrus sinensis L.Osbeck) sobre portaenxertos limão 'Volkameriano' (Citrus volkameriana Pasquale) e citrumelo 'Swingle' (Poncirus trifoliata x Citrus paradisi) através de interenxertia em ambiente protegido

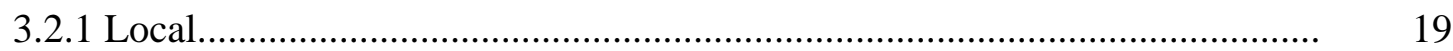

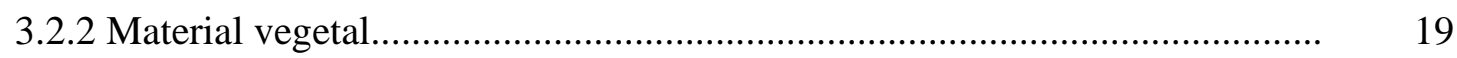

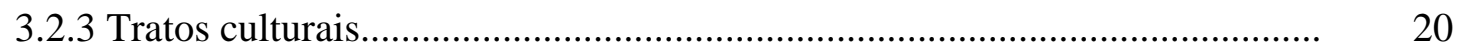

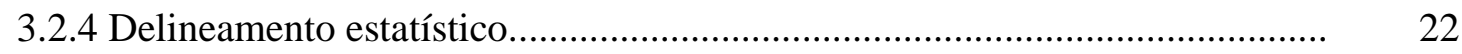

3.2.5 Dados biométricos coletados..................................................................... 22

3.3 Produção de estacas de citrumelo ‘Swingle’ (Poncirus trifoliata x Citrus paradisi) para fins de enxertia no viveiro e subenxertia no campo.................... 23

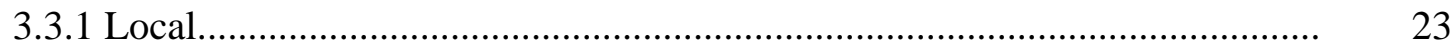

3.3.2 Material vegetal....................................................................................... 23

3.3.3 Tipos de estacas.................................................................................. 24

3.3.4 Fitorreguladores...................................................................................... 25

3.3.5 Tratos culturais................................................................................... 25

3.3.6 Delineamento estatístico............................................................................ 26

3.3.7 Dados biométricos coletados....................................................................... 26

4 RESULTADOS E DISCUSSÃO................................................................ 28

4.1 Desenvolvimento de onze porta-enxertos em diferentes recipientes para fins de subenxertia............................................................................... 28

4.1.1 Comparação de custos de produção......................................................... 43

4.2 Produção de mudas de laranja 'Pêra' (Citrus sinensis L.Osbeck) sobre portaenxertos limão 'Volkameriano' (Citrus volkameriana Pasquale) e citrumelo ‘Swingle’ (Poncirus trifoliata x Citrus paradisi) através de interenxertia em ambiente protegido..................................................................................... 45

4.2.1 Comparação de custos de produção............................................................... 48

4.3 Produção de estacas de citrumelo ‘Swingle’ (Poncirus trifoliata x Citrus paradisi) para fins de enxertia no viveiro e subenxertia no campo................ 54

4.3.1 Comparação de custos de produção............................................................... 58 


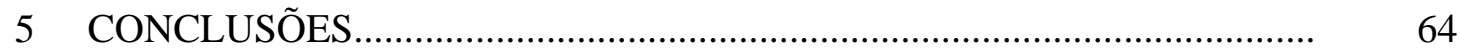

REFERÊNCIAS BIBLIOGRÁFICAS.................................................................. 65 


\section{LISTA DE TABELAS}

Página

1 Emergência de onze porta-enxertos 7, 14, 21 e 28 dias após a semeadura em recipientes de diferentes volumes. Piracicaba, 2003.

2 Emergência de onze porta-enxertos 35, 42, 49 e 56 dias após a semeadura em recipientes de diferentes volumes. Piracicaba, 2003.

3 Altura de onze porta-enxertos 60, 90 e 120 dias após semeadura em quatro sistemas de produção. Piracicaba, 2004

4 Altura de onze porta-enxertos 150, 180 e 210 dias após semeadura em quatro sistemas de produção. Piracicaba, 2004

5 Altura e diâmetro a 35cm do colo de onze porta-enxertos, 240 dias após semeadura em quatro sistemas de produção. Piracicaba, 2004.

6 Matéria fresca de sistema radicular (MFR) e matéria seca de sistema radicular (MSR) de onze porta-enxertos, 240 dias após semeadura em quatro sistemas de produção. Piracicaba, 2004.

7 Matéria fresca de parte aérea (MFA) e matéria seca de parte aérea (MSA) de onze porta-enxertos, 240 dias após semeadura em quatro sistemas de produção. Piracicaba, 2004

8 Concentração de clorofila nas folhas e volume de sistema radicular de onze porta-enxertos cítricos, 270 dias após semeadura em quatro sistemas de produção. Piracicaba, 2004. 
9 Custos de produção de porta-enxertos para fins de subenxertia em três sistemas de produção. Piracicaba, 2005.

10 Sobrevivência de enxertia e comprimento de interenxerto de laranjas 'Pêra', 'Valência’ e ‘Hamlin’ e tangerinas ‘Sunki’ e ‘ Cleópatra’ enxertadas sobre citrumelo ‘Swingle’ e limão ‘Volkameriano’ 60, 90, 120 e 150 dias após a enxertia. Piracicaba, 2004.

11 Percentagem de borbulhas dormentes e comprimento de enxerto de-laranja 'Pêra' enxertada sobre interenxertos de laranjas 'Pêra', 'Valência' e 'Hamlin’ e tangerinas ‘Sunki’ e ‘Cleópatra’, sobre porta-enxertos citrumelo 'Swingle’ e limão 'Volkameriano', 100 dias após a enxertia. Piracicaba, 2004

12 Diâmetros de enxerto, interenxerto e porta-enxerto de mudas de laranja 'Pêra' enxertada sobre interenxertos de laranjas 'Pêra', 'Valência’ e ‘Hamlin’ e tangerinas 'Sunki’ e 'Cleópatra', sobre porta-enxertos citrumelo 'Swingle’ e limão 'Volkameriano’, 100 dias após a enxertia. Piracicaba, 2004.

13 Matérias fresca e seca de parte aérea e sistema radicular de mudas de laranja 'Pêra' enxertada sobre interenxertos de laranjas 'Pêra', 'Valência' e 'Hamlin' e tangerinas 'Sunki’ e ‘Cleópatra', sobre porta-enxertos citrumelo 'Swingle’ e limão ‘Volkameriano’, 100 dias após a enxertia. Piracicaba, 2004.

14 Custos de produção de muda de laranja 'Pêra' interenxertada em diferentes variedades. Piracicaba, 2005

15 Percentagem de sobrevivência, brotamento e enraizamento de estacas herbáceas, semi-lenhosas e lenhosas de citrumelo 'Swingle', submetidas a enxertia e imersão em solução com IBA 0 e 500 $\mathrm{mg} \mathrm{L}^{-1}$, 90 dias após estaquia em câmara de nebulização. Piracicaba, 2004.

16 Sobrevivência de enxertia, número de raízes principais e comprimento de maior raiz de estacas herbáceas, semi-lenhosas e lenhosas de citrumelo 'Swingle', submetidas a enxertia e imersão em solução com IBA 0 e 500mg $\mathrm{L}^{-1}$, 90 dias após estaquia em câmara de nebulização. Piracicaba, 2004......... 
17 Comprimento, diâmetro e sobrevivência de enxertia de estacas herbáceas, semi-lenhosas e lenhosas de citrumelo 'Swingle', submetidas a enxertia e imersão em solução com IBA 0 e 500 $\mathrm{mg} \mathrm{L}^{-1}$, 210 dias após transplante (DAT) para sacolas de 4,5L com substrato. Piracicaba, 2004..

18 Matéria seca de parte aérea e sistema radicular e volume de sistema radicular de estacas herbáceas, semi-lenhosas e lenhosas de citrumelo 'Swingle', submetidas a enxertia e imersão em solução com IBA 0 e 500mg L ${ }^{-1}, 210$ dias após transplante (DAT) para sacolas de 4,5L com substrato.

Piracicaba, 2004.

19 Custos de produção de subenxertos e mudas obtidas de estacas enraizadas de citrumelo ‘Swingle’. Piracicaba, 2005. 


\section{LISTA DE FIGURAS}

Página

1 Sistema radicular de plantas de limão ‘Cravo’: (A) Tubetes de 290 mL, (B) Sacolas de 1,7L, (C) Tubetes de $75 \mathrm{~mL}$ transplantados para sacolas de 1,7L, (D) Tubetes de $75 \mathrm{~mL}$ transplantados para sacolas de 4,5L. Piracicaba, 2004 


\title{
MÉTODOS ALTERNATIVOS DE PRODUÇÃO DE MUDAS CÍTRICAS EM RECIPIENTES NA PREVENÇÃO DA MORTE SÚBITA DOS CITROS
}

\author{
Autor: EDUARDO AUGUSTO GIRARDI
}

Orientador: Prof. Dr. FRANCISCO DE ASSIS ALVES MOURÃO FILHO

\section{RESUMO}

A Morte Súbita dos Citros (MSC) é uma nova doença que afeta a citricultura paulista, podendo levar à morte de milhões de plantas cítricas enxertadas sobre limão ‘Cravo' (Citrus limonia Osbeck), com um impacto comparável ao do vírus da Tristeza dos Citros durante as décadas de 30 e 40 . Técnicas alternativas na propagação dos citros podem contornar os efeitos da MSC, seja diretamente, pela produção de subenxertos tolerantes, ou indiretamente, pelo emprego de estaquia de citros e interenxertia em combinações copa/porta-enxerto incompatíveis, mas sobre porta-enxertos tolerantes à MSC. O presente trabalho visou avaliar diferentes métodos de produção de mudas cítricas em recipientes que proporcionem possível prevenção futura das plantas à MSC em condições de campo, através de três experimentos. 1) desenvolvimento de onze porta-enxertos para fins de subenxertia, em diferentes recipientes. Os recipientes usados foram tubetes de $290 \mathrm{~mL}$, sacolas de 1,7L e porta-enxertos transplantados de tubetes de 75mL para sacolas de 1,7L e 4,5L; 2) viabilização de produção de mudas de laranja 'Pêra' (Citrus sinensis L. Osbeck) sobre porta-enxertos citrumelo 'Swingle’ (Poncirus 
trifoliata x Citrus paradisi) e limão 'Volkameriano’ (Citrus volkameriana Pasquale), através de interenxertos de laranjas 'Valência’ e 'Hamlin’(Citrus sinensis L. Osbeck), tangerina 'Sunki' (Citrus sunki Hort. ex Tanaka) e tangerina 'Cleópatra' (Citrus reshni Hort. ex Tanaka); 3) produção de mudas cítricas e subenxertos a partir de estacas enraizadas de citrumelo 'Swingle'. Utilizaram-se estacas herbáceas, semi-lenhosas e lenhosas obtidas de porta-enxertos de seis meses de idade, submetidas a imersão em solução com IBA 0 ou 500 $\mathrm{mg} \mathrm{L}^{-1}$ e a enxertia antes do enraizamento. Porta-enxertos produzidos diretamente em sacolas de 1,7L atingiram ponto ideal de subenxertia em menor tempo, ou seja, cerca de 100 a 150 dias após a semeadura, além de permitir a obtenção de plantas maiores e com sistema radicular adequado em mesmo espaço de tempo, quando se necessitar de subenxertos mais vigorosos no campo. A interenxertia se mostrou uma técnica promissora para propagação de citros, especialmente no caso de viabilizar o plantio de laranja 'Pêra' sobre citrumelo 'Swingle' em áreas afetadas pela MSC. Contudo, determina um ciclo de produção mais prolongado e com maior percentagem de descarte de mudas, levando-se até 17 meses para a formação da muda a partir da semeadura do porta-enxerto. Estacas herbáceas com um par de folhas são as mais indicadas para enraizamento e multiplicação de citrumelo 'Swingle'. 


\section{ALTERNATIVE PRODUCTION METHODS OF CONTAINER- GROWN CITRUS NURSERY TREES RELATED TO PREVENTION OF CITRUS SUDDEN DEATH DISEASE}

Author: EDUARDO AUGUSTO GIRARDI

Adviser: Prof. Dr. FRANCISCO DE ASSIS ALVES MOURÃO FILHO

\section{SUMMARY}

Citrus Sudden Death (CSD) is a new disease detected in the citrus industry in São Paulo State, Brazil. It affects all citrus varieties budded on 'Rangpur' Lime (Citrus limonia Osbeck), causing lost of vigor and leaf brightness, root system destruction, yield reduction, degeneration of rootstock phloem tissue and death of plants in few months. CSD has a great potential to destroy millions of plants such as Citrus Tristeza Virus has caused between 1930 and 1940. Alternative production methods of container-grown citrus nursery trees could prevent some effects of CSD, for instance, by the use of tolerant inarchings, citrus cuttings, or even interstocks in incompatible scion/rootstock combinations. This work evaluated the following alternative production methods of citrus aiming to prevent occurrence of CSD in groves: 1) production of citrus inarchings using eleven rootstocks in four container types: 290mL tubes and 1,7L and 4,5L plastic bags; 2) production of 'Pera' sweet orange (Citrus sinensis L. Osbeck) nursery trees on incompatible 'Swingle' citrumelo (Poncirus trifoliata x Citrus paradisi) and 'Volkamer' lemon (Citrus volkameriana Pasquale) with four interstocks: 'Valencia' and 'Hamlin' sweet oranges (Citrus sinensis L. Osbeck), 'Sunki' mandarin (Citrus 
sunki Hort. ex Tanaka) and 'Cleópatra’ mandarin (Citrus reshni Hort. ex Tanaka); 3) production of citrus inarchings and nursery trees using 'Swingle' citrumelo cuttings. Herbaceous, semi-hardwood and hardwood cuttings were used and were submitted to IBA solution ( 0 or $500 \mathrm{mg} \mathrm{L}^{-1}$ ) and budded before rooting. Production of inarchings directly sowed in 1,7L containers resulted in rootstocks ready for use about 100 to 150 days after sowing with more vigorous plants and well shaped root system. Interstocking is a promising citrus propagation technique especially regarding incompatible combinations, and could allow the use of 'Pera' sweet orange on 'Swingle' citrumelo in areas affected by CSD. On the other hand, the production cycle is longer, up to 17 months from sowing, besides producing a higher percentage of inadequate plants. Twoleaf herbaceous cuttings are indicated for appropriate rooting and multiplication of ‘Swingle’ citrumelo. 


\section{INTRODUÇÃO}

O Brasil é o maior produtor de laranja e maior exportador de suco de laranja concentrado congelado (SLCC) do mundo. Estima-se que a laranja, em conjunto com o café e a cana-de-açúcar, sejam as culturas responsáveis por cerca de 52\% do valor da produção agrícola do Estado de São Paulo. Além disso, o Estado de São Paulo é responsável por cerca de $80 \%$ da produção citrícola do Brasil. O setor emprega diretamente mais de 400 mil pessoas dentro do Estado de São Paulo, sustentando a economia de 316 municípios e atingindo a segunda colocação na pauta de produtos exportados pelo Estado (Fundecitrus, 2004a).

No Estado de São Paulo, a área colhida de citros ocupou, até junho de 2004, aproximadamente 580 mil ha, com uma produção total de cerca de 331 milhões de caixas de 40,8 kg na safra 04/05 (FNP, 2005). Calcula-se que cerca de 70\% do parque citrícola utiliza um único porta-enxerto, o limão ‘Cravo’. A população de cultivares comerciais de laranja doce é composta basicamente por 'Pêra' (45\% das plantas), 'Natal' (24\%), 'Valência' (13\%) e 'Hamlin' (5\%). As outras cultivares representam cerca de 13\% do total. O Estado tem quatro regiões citrícolas: Sul, Central, Norte e Noroeste. As principais áreas produtoras são Barretos, Araraquara, Jaboticabal/Bebedouro e Limeira, compondo o cinturão citrícola do Estado e concentrando cerca de 50\% do total de plantas e 50\% da produção. A produtividade média está em torno de 30 a $50 \mathrm{t} \mathrm{ha}^{-1} \mathrm{com}$ cerca de 312 plantas há ${ }^{-1}$. A citricultura paulista ainda se caracteriza pela ausência de irrigação em larga escala, hoje presente em cerca de $10 \%$ da área produtiva total. As principais doenças são clorose variegada dos citros, cancro cítrico, pinta preta, declínio, gomose e leprose dos citros, além das recentes morte súbita dos citros (MSC) e “greening”. As pragas chaves são as moscas-das-frutas e ácaros (Fundecitrus, 2004a). 
Em 1999, constatou-se oficialmente a presença da doença morte súbita dos citros (MSC) na região norte de São Paulo (região de Colômbia) e Sul de Minas Gerais (região de Comendador Gomes), ainda de causa desconhecida (Fundecitrus, 2005). A doença afeta todas as principais variedades comerciais de laranja doce, especialmente as tardias, enxertadas sobre limão ‘Cravo’ e limão ‘Volkameriano’ (Fundecitrus, 2004b). A planta perde o brilho das folhas e ocorre declínio rápido, especialmente a partir do início da primavera, podendo ocorrer morte da planta em quatro a cinco meses (Müller et al., 2002). Todo o sistema radicular fica comprometido com destruição das radicelas e há sintoma típico de amarelecimento do floema do porta-enxerto. A doença vem se manifestando em plantas jovens e adultas indiscriminadamente, tendo um período de incubação de dois a três anos, levando-se de dois a seis anos para que 95\% de uma talhão esteja afetado quando 5\% de plantas sintomáticas são constatadas (Jesus Jr et al., 2004). Ainda não se confirmou irrefutavelmente um patógeno como agente causal, nem ligação com o declínio dos citros, contudo uma das principais hipóteses é de que se trata de uma estirpe mutante do vírus da tristeza que afetaria o limão 'Cravo' e o limão 'Volkameriano', possivelmente, transmitida pelo pulgão preto dos citros Toxoptera citricida, tal qual o quick decline da laranja azeda ${ }^{1}$. Outras hipóteses levantadas seriam que fatores abióticos conjugados, como estresse hídrico, nutrição desbalanceada e produção excessiva, provocariam a doença, ou ainda que a causa real resultaria da ação de um vírus da família Tymoviridae, provavelmente em associação ao vírus da Tristeza, em condições ambientais favoráveis à manifestação de sintomas pelas plantas, como no norte do Estado (Fioravanti, 2005; Fundecitrus, 2004b). Maccheroni et al. (2005) identificaram e caracterizaram um novo vírus (citrus sudden death-associated virus ou CSDaV) do gênero Marafivirus, família Tymoviridae, associado exclusivamente com plantas afetadas pela MSC e também presente em pulgão preto dos citros, sendo assim possível agente etiológico da doença. A MSC, que já afetou desde 1999 cerca de um milhão e meio de plantas em Minas Gerais e São Paulo, se desloca a cerca de 40 km por ano. Uma vez que a região norte de São Paulo concentra hoje a produção de citros do Estado e que cerca de $80 \%$ dos 200 milhões de plantas cítricas sejam enxertadas sobre

\footnotetext{
${ }^{1}$ MÜLLER, G.W. Comunicação pessoal, 2003.
} 
limão 'Cravo', pode-se dimensionar o impacto letal da MSC na citricultura paulista e o caráter emergencial de solucionar ou contornar tais reflexos.

Portanto, dado o sério risco que a MSC representa à citricultura paulista, urge-se por tecnologia de propagação de citros visando-se a prevenção da doença, desenvolvendo-se conhecimento que se antecipe à manifestação de problemas no campo. Para tanto, é imprescindível avaliar técnicas de produção de porta-enxertos para fins de subenxertia, de forma a contemplar a maior diversificação de porta-enxertos possível, bem como outras técnicas de propagação sob cultivo protegido que contribuam à solução do problema. Como exemplo, cita-se a estaquia de porta-enxertos ou ainda o emprego de interenxertia para viabilizar combinações incompatíveis de copa e portaenxertos que conjuguem características horticulturais interessantes à produção com a necessidade de diversificação de porta-enxertos para áreas afetadas pela MSC. Sendo assim, o presente trabalho teve como objetivos:

- Avaliar o desenvolvimento de onze porta-enxertos para fins de subenxertia, em diferentes recipientes sob cultivo protegido.

- Avaliar a viabilidade de produção de mudas de laranja 'Pêra' sobre portaenxertos citrumelo 'Swingle' e limão 'Volkameriano' através de interenxertia, contornando o problema da incompatibilidade destas combinações;

- Avaliar a produção de mudas cítricas a partir de estacas enraizadas de citrumelo 'Swingle', em função de maturidade de estacas, momento da enxertia e tratamento de estacas com fitorreguladores. 


\section{REVISÃO DE LITERATURA}

\subsection{Morte Súbita dos Citros}

Uma nova doença foi observada em 1999 no sudoeste de Minas Gerais e no norte de São Paulo afetando laranjas doces (Citrus sinensis L.Osbeck) enxertadas em limão 'Cravo' (Citrus limonia Osbeck) (Gimenes-Fernandes \& Bassanezi, 2001; Müller et al., 2002). A doença foi denominada de morte súbita dos citros (MSC) por pesquisadores do Centro APTA Citros Sylvio Moreira, em vista da rapidez com que as plantas sucumbem (Centro de Citricultura Sylvio Moreira, 2001).

As árvores afetadas inicialmente apresentam folhas verde-pálidas e queda pronunciada, morte apical de ramos e, ocasionalmente, desenvolvimento de pequeno número de ramos “ladrões” na copa. No estádio final, todas as folhas caem e a árvore morre, permanecendo com alguns frutos presos aos galhos. Os sintomas já foram encontrados em plantas com dois anos de idade, porém, são mais freqüentes em árvores além de seis anos, e mais pronunciados na primavera (Müller et al., 2002). As árvores geralmente morrem cerca de seis meses após o aparecimento dos sintomas, conforme o cultivar (Jesus Jr et al., 2004). Exames dos tecidos mostram amarelecimento do floema no porta-enxerto, sendo este o sintoma mais característico no diagnóstico da doença, precedendo o declínio da copa, não sendo observada incompatibilidade na região de enxertia. O sistema radicular de árvores afetadas tem menos radicelas que as sadias, com diferentes intensidades de podridão. As combinações afetadas de laranjas 'Valência' e 'Natal' enxertadas em limão 'Cravo', acabam morrendo, o que raramente acontece com aquelas de laranjas 'Pêra', 'Hamlin’ e ‘Westin’ sobre o mesmo porta-enxerto (Bassanezi et al., 2002). O problema foi observado também em laranjas 'Natal' enxertadas em 
limão 'Volkameriano’ (Citrus volkameriana Tenn. et Pasq.). As árvores enxertadas sobre tangerina 'Cleópatra' (Citrus reshini Hort. Ex Tan.), citrumelo 'Swingle' (Poncirus trifoliata L. Raf. X Citrus paradisi Macf. e trifoliata (Poncirus trifoliata L. Raf.) próximas a plantas com MSC não mostram sintomas.

Atualmente, a principal hipótese sobre a etiologia da doença é que seja causada por um novo vírus do gênero Marafivirus, chamado de citrus sudden death-associated virus ou $\mathrm{CSDaV}$, transmitido pelo pulgão preto dos citros Toxoptera citricida (Maccheroni et al., 2005). Não existem fatos que demonstrem claramente que haja uma estirpe mutante de citrus Tristeza virus provocando a doença ou que os dois vírus estejam em associação nas plantas sintomáticas.

\subsection{Emprego de subenxertia em citricultura}

A subenxertia foi utilizada com sucesso como técnica de prevenção à tristeza dos citros afetando porta-enxerto laranja azeda em países como Espanha e Israel (Moreno et al., 1994; Shaked et al., 1987). O citrumelo 'Swingle' em particular se mostrou um excelente porta-enxerto para fins de subenxertia, sendo que quanto mais novos forem os subenxertos e as plantas a ser subenxertadas, mais rápida é a recuperação, sem prejuízo algum à produção da copa (Shaked, 1987).

No Brasil, a subenxertia vem sendo utilizada como técnica horticultural de prevenção da MSC em pomares onde ainda não se observa a doença ou recuperação de plantas em estádios iniciais de manifestação de sintomas (Tersi et al., 2003). Para tanto, empregam-se porta-enxertos aparentemente tolerantes à MSC, como citrumelo 'Swingle’ e tangerina 'Cleópatra', subenxertados a 35cm do nível do solo em tecido da copa. Para o método do T-invertido, os porta-enxertos devem apresentar diâmetro de cerca de 0,3 a 1cm nesta altura, com tecido maduro. Utiliza-se de um a quatro subenxertos por árvore, conforme idade, condições técnicas e grau de infestação de MSC do pomar. Cerca de cinco milhões de subenxertos já foram realizados, e é a única forma de controle da doença atualmente, além de não acarretar diminuição na produção ou longevidade dos pomares. Muitos viveiristas de citros chegam a subenxertar as próprias mudas cítricas dentro do viveiro, no caso de plantas enxertadas em limão 
'Cravo', de modo a não perder encomendas anteriores à constatação da MSC ou ainda na falta de sementes de porta-enxertos tolerantes. A produção de porta-enxertos aptos à subenxertia em curto prazo e sob cultivo protegido ainda carece de informações técnicas, além de existir a necessidade de diversificação dos porta-enxertos empregados na citricultura a fim de reduzir o impacto de doenças como a MSC, sem no entanto acarretar prejuízos à produtividade dos pomares.

A subenxertia é uma técnica simples de enxertia, que permite configurar à copa novos porta-enxertos, para substituir o original afetado por problemas fitossanitários como é o caso da gomose, das podridões de raiz e da tristeza, por problemas traumáticos ou por intolerância a outras moléstias de vírus como a exocorte e a xiloporose, que causam deficiências no desenvolvimento das plantas (Salibe, 1969). A subenxertia consiste no plantio de um a quatro novos porta-enxertos ao redor do tronco da árvore. Inicialmente, devem ser escolhidos para esta operação porta-enxertos bastante vigorosos, com a grossura aproximada de $0,7 \mathrm{~cm}$ na altura da enxertia. A ponta de cada portaenxerto é cortada em bisel e introduzida em uma janela aberta no tronco, acima do ponto de união copa-porta-enxerto. O uso de um prego fino é recomendado para garantir a firme aderência do porta-enxerto contra o tronco. A amarração é feita com uma fita plástica larga para evitar a penetração de água na ferida e facilitar a soldadura dos tecidos. A subenxertia funciona bem para árvores jovens, até dez anos de idade. Os novos porta-enxertos rejuvenescem a árvore doente, injetando seiva na copa, que então emitem ramos vigorosos, retomando a produtividade.

É freqüente nos laranjais de São Paulo a morte de árvores jovens afetadas especialmente pela podridão do pé ou gomose de Phytophthora. O limão 'Cravo', principal porta-enxerto usado, é muito suscetível a essa doença, que depaupera as plantas pela destruição dos tecidos na região do colo. A tangerina 'Cleopatra' e o limão 'Volkameriano’ são mais resistentes à gomose que o limão ‘Cravo’. Poncirus trifoliata e citrumelo 'Swingle' são resistentes à gomose, e todos eles podem ser utilizados como porta-enxertos para recuperar as árvores afetadas ou ameaçadas pela MSC. No caso particular de cultivares intolerantes, como a lima ácida 'Tahiti’ em relação à gomose, a subenxertia pode ser a única garantia de sobrevivência do pomar (Salibe, 1969). 


\subsection{Emprego da estaquia em citricultura}

Os porta-enxertos cítricos são multiplicados, na maioria das vezes, por sementes, sendo, em sua grande maioria, poliembriônicos, portanto estando sujeitos à ocorrência de variabilidade e levando à produção tanto de indivíduos geneticamente diferentes da planta matriz como de plantas nucelares (Rocha et al., 1988).

Diante da legislação atual de manutenção de matrizes e produção de mudas cítricas em ambiente protegido (Panzani et al., 1994), a propagação de porta-enxertos pelo método de estaquia surge como uma alternativa para produção de mudas e portaenxertos, com as vantagens adicionais de redução do tempo de produção da muda, preservação das características desejáveis da planta matriz e redução do porte da planta (Ferri, 1997). A redução do porte facilita os tratos culturais e a manutenção destas plantas em ambiente protegido.

O enraizamento de estacas de citros, tanto para enxertia como para subenxertia, constitui técnica promissora, embora com dificuldades de emprego comercial, tanto pela grande diversidade de taxas de enraizamento das diferentes espécies cítricas, dificuldades de controle na aplicação de tratamentos com fitorreguladores como também por maiores cuidados despendidos na implantação dos pomares de mudas de estacas, por exemplo, no controle de Phytophthora (Ferri, 1997). Por outro lado, permite rápida obtenção de porta-enxertos com dificuldade de multiplicação por sementes, seja esta inerente à espécie, ou simplesmente pela inexistência de plantas matrizes suficientes para fornecer a quantidade de sementes demandada pelos viveiristas. Pode ainda ser uma forma de aproveitamento de copas de porta-enxertos, em geral descartadas após o encurvamento para forçamento da enxertia, ampliando a disponibilidade de material propagativo.

A estaquia semi-lenhosa ou o emprego de estacas previamente enxertadas despontam como alternativas mais viáveis de multiplicação de material, buscando-se acelerar o processo de obtenção de mudas enxertadas ou porta-enxertos para fins de subenxertia (Koller et al., 2000; Prati et al., 1999). 
A propagação de plantas por estacas baseia-se na capacidade de regeneração de tecidos e emissão de raízes adventícias. A formação das raízes em estacas depende de fatores internas da planta matriz, por exemplo, presença de hormônios e condições nutricionais, e fatores ambientais, por exemplo, temperatura e umidade (Hartmann et al., 2002). Segundo Fachinello et al. (1995), a produção de mudas por estaquia pode ser viável, sendo seu sucesso dependente da facilidade do enraizamento de cada espécie, da qualidade do sistema radicular formado e do desenvolvimento posterior da planta. A formação de raízes adventícias envolve uma seqüência de mudanças nos tecidos, onde cada estágio possui requerimento hormonal distinto (Pasqual et al., 2001). O estágio inicial é caracterizado por uma fase de resposta à auxina endógena e exógena, sendo sucedido por um estágio onde não ocorre mais resposta a este hormônio (Hartmann et al., 2002). A aplicação de auxinas sintéticas é prática comum no enraizamento de estacas, sendo o AIB (ácido indolbutírico) a auxina mais utilizada.

Diversas enfermidades podem surgir devido a não diversificação dos portaenxertos (Carlos et al., 1997). Alguns trabalhos têm demonstrado que o emprego de diferentes porta-enxertos permite a obtenção de diversas vantagens sobre o limão 'Cravo', convencionalmente empregado. Entre estas alternativas, destacam-se o 'Flying Dragon' (Poncirus trifoliata L. Raf. var. monstrosa) e o 'Trifoliata' (Poncirus trifoliata L. Raf.), que apesar de serem suscetíveis ao declínio, são tolerantes ao vírus da tristeza, apresentam boa adaptação a baixas temperaturas e induzem menor porte nas copas neles enxertadas, além de conferirem qualidades visual e de suco superiores aos frutos (Pompeu Jr, 1991; Martínez-Pérez, 1999). Pio et al. (2002), trabalhando com enraizamento de estacas dos porta-enxertos ‘Flying Dragon’ (Poncirus trifoliata L.) e 'Trifoliata' (Poncirus trifoliata L. Raf.), submetidas a soluções com diferentes concentrações de IBA, concluíram que as concentrações de $400 \mathrm{mgL}^{-1}$ e $200 \mathrm{mgL}^{-1}$ resultaram em maior porcentagem de enraizamento para 'Trifoliata' e para 'Flying Dragon', respectivamente, sendo que a maior quantidade de biomassa fresca nos dois porta-enxertos foi obtida com $400 \mathrm{mg} \mathrm{L}^{-1}$. 


\subsection{Emprego de interenxertia em citricultura}

Uma compatibilidade harmoniosa entre os tecidos do tronco na união copacavalo é essencial na busca da alta produtividade. A incompatibilidade copa-portaenxerto é responsável por árvores de pouco vigor e baixa produtividade e, freqüentemente, leva à morte pomares inteiros. O citricultor precisa conhecer as combinações incompatíveis e evitá-las na formação de seus pomares.

As incompatibilidades mais comuns são decorrentes de fatores fisiológicos, podendo ser evitadas pelo emprego da dupla enxertia, introduzindo-se uma variedade compatível entre a copa e o porta-enxerto. A incompatibilidade copa-porta-enxerto pode aparecer ainda no viveiro ou tardar cinco a dez anos para se manifestar. Os sintomas na região da união copa e porta-enxerto ocorrem sob a forma de uma seqüência de pontos de goma na casca, que se unem em uma linha de impedimento à passagem de seiva. Também no lenho forma-se uma linha deprimida onde penetram projeções da casca (Moreno et al., 1994; Salibe, 1969). Os casos mais conhecidos de incompatibilidade são laranja 'Pêra' enxertada em Poncirus trifoliata e seus híbridos e em limões 'Volkameriano’ e ‘Rugoso da Flórida' (Pompeu Jr, 1991). A laranja 'Pêra’ é compatível com limão ‘Rugoso Nacional’. Os limões 'Siciliano’ e ‘Eureca’ são incompatíveis com Poncirus trifoliata e seus híbridos. O tangor 'Murcote' é incompatível com o Poncirus trifoliata, mas os sintomas de rejeição são moderados e tardam no geral mais de dez anos para se manifestar. Assim, essa combinação pode ser usada comercialmente, quando se faz necessário um porta-enxerto resistente à gomose. A severidade ou grau de incompatibilidade é influenciado por clones e ainda pela temperatura, sendo mais grave nos climas mais quentes.

A interenxertia é uma técnica de propagação de citros que visa, principalmente, contornar problemas de incompatibilidade entre copa e porta-enxerto sem acarretar prejuízos à produtividade esperada pela combinação, embora lhe possa conferir novas características, como redução de tamanho da copa (Valente, 1993). Também pode ser empregada em qualquer ocasião em que se buscam características horticulturais obtidas pela técnica, e não necessariamente para se contornar a incompatibilidade de tecidos. Alguns interenxertos ou filtros, como Poncirus trifoliata entre laranja 'Valência' e limão 
‘Cravo', chegam a alterar época de frutificação, sendo que altura na enxertia ou extensão de interenxerto não afetam nem desenvolvimento nem produção das plantas (Sampaio, 1993).

Estudos buscando associar a presença de doenças, como o declínio dos citros, e plantas interenxertadas já foram realizados no Brasil (Carlos, 1996). Contudo, somente plantas com interenxerto tangerina 'Batangas' não demonstraram sintomas da doença. A interenxertia não impede o translocamento de vírus e viróides entre copa e porta-enxerto, portanto não previne doenças do tipo copa/porta-enxerto como a tristeza dos citros (Bitters et al., 1981). Se a possibilidade de controlar a doença diretamente é remota, a interenxertia poderia viabilizar combinações de importante impacto econômico. Como a laranja 'Pêra' é a principal variedade copa no Estado com menor número de opções de variedades de porta-enxertos compatíveis quando comparada às demais laranjas doces comerciais (Figueiredo, 1991) e, diante da impossibilidade de continuar usando o limão 'Cravo’ como porta-enxerto, a viabilização de seu uso com o citrumelo 'Swingle’ via interenxertia é uma forma de evitar que a variedade passe a ser enxertada quase que exclusivamente sobre tangerina 'Sunki', conforme se verifica nos atuais plantios em áreas onde a MSC já está presente. O citrumelo 'Swingle’ é porta-enxerto que induz maior tolerância à seca em relação à tangerina 'Sunki', além de ser resistente à Phytophthora, o que ampliaria a viabilidade do plantio de laranja 'Pêra' em regiões de maior déficit hídrico, justamente nas regiões norte de São Paulo e Triângulo Mineiro. Desta forma, se estaria contribuindo para a diversificação de combinações copa/portaenxerto nos novos plantios, propiciando mais alternativas ao citricultor, evitando-se a repetição de um quadro que resultou nos impactos da tristeza dos citros e hoje da MSC.

Hartmann \& Kester (1983) relacionaram várias razões para o emprego da interenxertia ou dupla enxertia na propagação de plantas. Uma delas seria o de contornar os efeitos de incompatibilidade, outra é a possibilidade do filtro possuir característica não existente na copa, nem no porta-enxerto, a qual o faz importante no todo. Uma terceira razão para o emprego da dupla enxertia é quando o filtro pode ter influência no desenvolvimento da planta. Segundo Bitters et al. (1981a), estes filtros usualmente 
provocam pequenas alterações na fisiologia da planta, pois, os maiores efeitos são exercidos pelos porta-enxertos.

Bitters et al. (1981a e 1981b) pesquisando os efeitos de dupla enxertia em citros, usaram copa de laranja 'Valencia' e porta-enxertos de tangerina ‘Cleopatra' e citrange 'Troyer', assim como filtros destes mesmos materiais reciprocamente. Fazendo variações no posicionamento e na extensão destes filtros, concluíram que filtros de citrange 'Troyer' com $15 \mathrm{~cm}$, inseridos a $15 \mathrm{~cm}$ de altura, resultaram em plantas com maiores produções. Inserções mais altas dos filtros (30 e 40cm) resultaram em menores produções. Verificaram também que as plantas com filtros apresentaram menores volumes e produções levemente inferiores, quando comparadas as plantas sem filtros. Fazendo variações nos tamanhos dos filtros $(5,15,30,45$ e $60 \mathrm{~cm})$ inseridos sempre a mesma altura de $15 \mathrm{~cm}$, ocorreram copas maiores para plantas portadoras de filtros com $15 \mathrm{~cm}$ de extensão. No mesmo trabalho, fazendo-se uso de filtros de tangerina 'Cleopatra', verificou-se que aqueles com $15 \mathrm{~cm}$ de extensão, quando colocados a diferentes alturas propiciaram maiores produções quando inseridos a $30 \mathrm{~cm}$. As maiores plantas foram aquelas com inserção dos filtros a $5 \mathrm{~cm}$ e não a $15 \mathrm{~cm}$, como ocorreu para o citrange 'Troyer'. Plantas com filtros apresentaram produções e volumes menores do que aquelas sem filtros, cerca de metade da produção e dois terços do tamanho.

De acordo com Bitters et al. (1981a) e Sampaio (1990), o emprego de interenxertos em plantas cítricas não determinou variações nas características dos frutos. Por outro lado, Llorente et al. (1984) verificaram variações no teor de acidez, comprimento dos frutos e espessura da casca do limão 'Verna', enxertado na laranja azeda, por influência de filtros de cultivares de laranjas doces. Os teores de nutrientes das folhas da laranja 'Valencia' não sofreram variações em função do emprego de interenxertos (Labanaukas \& Bitters, 1974; Sampaio, 1990).

Em experimento realizado por Sampaio (1993), mudas cítricas foram obtidas por dupla enxertia, com interenxerto de Poncirus trifoliata a 5, 10 e $20 \mathrm{~cm}$ de extensão sendo posteriormente enxertadas com borbulhas de laranja 'Valencia' enquanto outras foram obtidas a partir de enxertia simples realizada a 15, 25 e 35cm do solo. A comparação das médias das circunferências dos troncos, alturas, diâmetros e volumes de copas obtidos a 
partir destas plantas aos oito anos de idade permitiu concluir que o emprego de interenxertos de Poncirus trifoliata na combinação laranjeira 'Valencia' sobre limão ‘Cravo’ provocou alterações no desenvolvimento das plantas cítricas, resultando em redução no tamanho das plantas e atraso no início da frutificação além da menor produção de frutos. Dentro dos limites estudados, as variações nas extensões dos interenxertos de Poncirus trifoliata e as diferentes alturas de enxertia não afetaram o desenvolvimento e a produção da laranjeira ‘Valencia’ enxertada em limão ‘Cravo’.

\subsection{Sistema comercial de produção de mudas cítricas no Estado de São Paulo}

A muda é um dos insumos mais importantes para a formação de um pomar de citros, tendo-se em vista o caráter perene da cultura. A importância da muda está no fato de que o potencial máximo de produtividade e de qualidade das frutas será revelado seis a oito anos após o plantio e a longevidade do pomar só será conhecida em um intervalo de tempo ainda maior (Teófilo Sobrinho, 1991).

Com o objetivo de melhorar a qualidade das mudas cítricas utilizadas no Estado de São Paulo, a Secretaria de Agricultura instituiu o "Programa de Certificação de Mudas Cítricas do Estado de São Paulo”, que determina o uso de ambiente fechado ou telado, onde as mudas devem ser produzidas em recipientes, com substrato e água desinfetados e materiais vegetais indexados para viroses e para a CVC (Panzani et al, 1994). Borbulhas e sementes para a produção de mudas também devem respeitar as mesmas condições de produção protegida, sendo que todo material propagativo deve ser originado de borbulheiras e plantas matrizes teladas e certificadas. A disponibilidade de sementes e borbulhas, tanto em termos qualitativos quanto em termos quantitativos, é fundamental para a viabilização de toda a cadeia de produção de mudas cítricas, conferindo maleabilidade e continuidade ao processo. De acordo com este Programa, após 1 de julho de 2000, as sementeiras para a produção de porta-enxertos de citros somente deveriam ser instaladas em ambiente telado à prova de afídeos; a partir de 1 de janeiro de 2001, só seriam registrados viveiros para produção de mudas cítricas instaladas em ambiente telado e porta-enxertos utilizados nos viveiros deveriam ser obrigatoriamente provenientes de instalações teladas à prova de insetos; e depois de 1 de 
janeiro de 2003, tornaram-se proibidos em todo o território do Estado de São Paulo o comércio e o transporte de porta-enxertos e mudas cítricas produzidas em viveiros sem proteção contra insetos (Fundecitrus, 2003). Até janeiro de 2005, produziam-se cerca de 13 milhões de mudas e 9 milhões de porta-enxertos nos 558 viveiros paulistas, sendo a totalidade da produção em ambiente telado (Fundecitrus, 2005).

Quanto à produção de mudas cítricas em recipientes, apontam-se diversas vantagens, tais como: seleção apurada dos porta-enxertos, maior controle sobre patógenos, acarretando em melhor sanidade, menor tempo para obtenção de mudas, maior volume de radicelas, maior sobrevivência no plantio, menor número de regas pósplantio, maior controle nutricional e maior produção de mudas por unidade de área (Platt \& Opitz, 1973). Entre as desvantagens, indicam-se: produção de mudas menores, carentes de maiores cuidados no primeiro ano após o plantio, controle de condições ambientais implicando maiores custos iniciais e possibilidade de necessidade de transplante para recipientes maiores, se prolongada a permanência da muda na estufa (Gouin, 1979; Gomes, 1989). Diversas práticas culturais, da adubação ao sistema de forçamento da enxertia, interagem de forma complexa para determinar o desenvolvimento efetivo da muda no viveiro, sendo que a espécie porta-enxerto é um dos fatores preponderantes para indicar a intensidade do desenvolvimento da planta. Também a capacidade do recipiente, por ser diretamente proporcional à disponibilidade de recursos como água e nutrientes à planta, bem como acomodação do sistema radicular, é um fator decisivo para determinar a velocidade de crescimento do portaenxerto e da muda e indicar a viabilidade técnica-econômica do empreendimento (Girardi et al., 2001a).

Sendo assim, a produção de mudas ou porta-enxertos cítricos, mesmo para caráter emergencial como na situação de prevenção à MSC, não pode desrespeitar as normas de produção certificada. Na verdade, estas normas já se adaptaram às novas necessidades impostas pela MSC, conforme a portaria CDA-5 de 3 de fevereiro de 2005, que atualizou a legislação sobre produção certificada mudas cítricas (Coordenadoria de Defesa Vegetal, 2005), e as portarias CDA-14 a 16 de 15 de outubro de 2003, que determinaram prazo até 30 de julho de 2004 para troca as telas de $1 \mathrm{~mm}^{2}$ por novas telas 
anti-afídicas de malha ainda menor $(0,87 \mathrm{~mm}$ x 0,30mm), como medida de prevenção à MSC por evitar a penetração do pulgão preto, vetor do provável agente etiológico, dentro do viveiro (Vivecitrus, 2004). 


\section{MATERIAL E MÉTODOS}

\subsection{Desenvolvimento de onze porta-enxertos em diferentes recipientes para fins de subenxertia}

\subsubsection{Local}

O trabalho foi conduzido em estufa comercial telada para produção de mudas cítricas, localizada no município de Araras, SP, $22^{\circ} 25^{\prime} 15^{\prime}$ ' S e $47^{\circ} 23^{\prime} 03^{\prime}$ 'W. O clima da região é do tipo Cwa, tropical úmido com estiagem no inverno, chuva de verão e com temperatura média, do mês mais quente, superior a $22^{\circ} \mathrm{C}$, e a do mês mais frio não inferior a $16^{\circ} \mathrm{C}$. Dentro da estufa verificam-se temperaturas máximas de até $45^{\circ} \mathrm{C}$ durante o período do ensaio.

\subsubsection{Material vegetal}

Foram avaliados 11 porta-enxertos, sendo oito atualmente de caráter comercial (limão ‘Cravo’ clone Limeira (Citrus limonia Osbeck); citrumelo 4475 ou 'Swingle' (Poncirus trifoliata x Citrus paradisi); tangerina 'Cleópatra' (Citrus reshni Hort. ex Tanaka); tangerina ‘Sunki’ (Citrus sunki Hort. ex Tanaka); limão ‘Volkameriano’ clone Catânia 2 (Citrus volkameriana Pasquale); laranja 'Caipira' clone DAC (Citrus sinensis L.Osbeck); limão 'Rugoso da África’ clone Mazoe (Citrus jambhiri Lush.) e Poncirus trifoliata 'Davis A') e três de caráter potencial para a citricultura brasileira - tangerina 'Sun Shu Sha Kat’(Citrus sunki Hort. ex Tanaka), tangerina 'Sunki’ 2506 ou clone Fruto Grande (Citrus sunki Hort. ex Tanaka) e Poncirus trifoliata 'Barnes'. 
Os porta-enxertos comerciais, a exceção do limão 'Cravo' e do limão 'Volkameriano', ainda não demonstraram intolerância à MSC em pomares, sendo seu uso recomendado pelo Fundecitrus para subenxertia. Os limões 'Cravo' e 'Volkameriano', por serem porta-enxertos usualmente produzidos em viveiros atualmente, serviram como testemunha para comparação com os demais porta-enxertos. Os porta-enxertos potenciais foram escolhidos por possível tolerância à MSC, além de terem apresentado produtividades agronômica e econômica comparáveis ou superiores às dos porta-enxertos comerciais, em ensaios de campo anteriores ${ }^{2}$. A tangerina 'Sunki Fruto Grande’ ainda apresenta uma característica importante, em média 18 sementes viáveis por fruto, contra duas a quatro na tangerina 'Sunki’ comum.

\subsubsection{Coleta de sementes e semeadura}

As sementes dos porta-enxertos foram obtidas de frutos maduros coletados no Banco de Germoplasma do Centro APTA Citros Sylvio Moreira em 10/06/2003. As sementes foram extraídas manualmente e submetidas a imersão de solução de água e cal virgem para facilitar retirada da mucilagem. Após este processo, passaram por secagem à sombra por 24 horas, sendo embaladas em jornal, com aplicação de fungicida apropriado, e levadas ao refrigerador do viveiro comercial, sendo mantidas a cerca de $5^{\circ} \mathrm{C}$ até a semeadura em 27/03/2003. Quando da semeadura, as sementes foram retiradas do refrigerador e tiveram seu tegumento externo (testa) extraído visando acelerar a emergência e, portanto, auxiliar na otimização da produção dos subenxertos (Girardi et al., 2001b). A extração foi manual após imersão por 45 minutos em solução abrasiva (4 L água + 1 L hipoclorito $+10 \mathrm{ml}$ ácido muriático). Após a retirada do tegumento, as sementes foram lavadas em água corrente e imediatamente semeadas.

A semeadura foi feita em $27 / 07 / 2003$, contudo foi repetida em $30 / 10 / 2003$, pois o primeiro ensaio instalado foi perdido após dois meses de sua instalação, devido a um erro de fertirrigação. Deste primeiro ensaio, apenas os dados referentes à emergência dos porta-enxertos foram coletados. As sementes que restaram da primeira semeadura foram mantidas em refrigerador, a $5^{\circ} \mathrm{C}$, até a segunda semeadura.

\footnotetext{
${ }^{2}$ POMPEU JR, J. Comunicação pessoal, 2003.
} 


\subsubsection{Recipientes}

Foram avaliados três recipientes, com finalidade exclusiva para subenxertia: Aprodução dos porta-enxertos semeados em tubetes de $290 \mathrm{~mL}$, em bancadas de arame suspenso; B- produção dos porta-enxertos semeados diretamente em sacolas plásticas de 1,7L, sobre bancadas de concreto; C- produção dos porta-enxertos em tubetes convencionais de $75 \mathrm{~mL}$ e posteriormente transplantio para sacolas plásticas de 1,7L. A produção dos porta-enxertos em tubetes convencionais de $75 \mathrm{~mL}$ e posterior transplantio para sacolas de 4,5L é o sistema convencionalmente empregado para fins de enxertia e formação das mudas no viveiro e funciona como testemunha para cada porta-enxerto.

\subsubsection{Tratos culturais}

Todos os porta-enxertos foram submetidos aos mesmos tratos culturais que evidenciam otimização da produção de porta-enxertos aptos à enxertia em curto prazo. Foi semeada manualmente uma semente sem testa em cada recipiente. Nos tubetes de 75mL utilizou-se substrato comercial Plantmax ${ }^{\circledR}$ Citrus, a base de casca de pinus e de baixa granulometria. Foram incorporados ao substrato $3 \mathrm{~kg} \mathrm{~m}^{-3}$ de superfosfato simples com o auxílio de uma betoneira. Nos demais recipientes (tubetes de $290 \mathrm{~mL}$ e sacolas plásticas), utilizou-se substrato comercial Rendmax® Citrus, também a base de pinus, mas de granulometria maior. A razão da escolha foi o menor preço do último substrato, bem como sua maior adaptação a recipientes de maior capacidade. Aplicaram-se $2 \mathrm{~g}$ de fertilizante de liberação controlada Osmocote ${ }^{\circledR} 22-04-08$ por recipiente $\left(2 \mathrm{~kg} \mathrm{~m}^{-3}\right.$ de substrato). As sementes foram recobertas por uma fina camada de Plantmax ${ }^{\circledR}$ Citrus em todos os tratamentos.

A irrigação foi manual, diária e iniciada imediatamente após o plantio. Dois meses após a semeadura, realizou-se raleio das plantas, eliminando-se as plantas zigóticas e nucelares menos desenvolvidas, deixando-se uma planta por container. Cerca de 15 dias depois, iniciou-se a fertirrigação, aplicada em todas as irrigações com fertilizante solúvel 24-08-16 a 0,5 g L ${ }^{-1}$. Aumentou-se a concentração da solução nutritiva para $1,2 \mathrm{~g} \mathrm{~L}^{-1}$, cerca de 4,5 meses após a semeadura, sendo esta mantida até o 
final do experimento. Quinzenalmente, realizou-se a desbrota dos porta-enxertos, visando manter o crescimento em haste única. Os porta-enxertos produzidos nos tubetes de $75 \mathrm{~mL}$ foram transplantados para as sacolas plásticas em 17/03/2004, aproximadamente 4,5 meses após a semeadura.

Durante todo o experimento, verificou-se ataque de lesmas desfolhando plantas. Seu controle foi feito com iscas lesmicidas, mantendo-se o ataque sob controle. Sempre que se realizou alguma pulverização nas demais bancadas da estufa, também se pulverizou o experimento. Assim, foi submetido esporadicamente à pulverização para controle de pulgões (deltametrina + óleo vegetal) e larva-minadora dos citros (abamectin) seguindo as recomendações dos fabricantes. Também foi realizada monda de trevinho (Oxalis spp.) e de outras plantas invasoras no substrato sempre que necessário. Este ensaio foi concluído em setembro de 2004, nove meses após a segunda semeadura.

\subsubsection{Delineamento estatístico}

O delineamento experimental adotado foi esquema fatorial $11 \times 4$ (porta-enxerto x sistema de produção), perfazendo 44 tratamentos em quatro repetições inteiramente casualizadas. A parcela experimental foi constituída de oito plantas, dispostas linearmente em bancadas ou em bandejas de tubetes. No total, foram utilizadas 1408 plantas, sendo 128 de cada porta-enxerto e 352 para cada sistema de produção. Inicialmente, foram previstas 12 plantas por parcela, contudo como foi necessário semear novamente em outubro, reduziu-se o número de plantas para oito por parcela, devido à menor quantidade de sementes disponíveis. No caso da análise estatística dos dados referentes à emergência, utilizou-se esquema fatorial $11 \times 3$, já que a etapa de semeadura em tubetes foi a mesma tanto para plantas transplantadas para sacolas de 1,7L quanto para as transplantadas para sacolas de 4,5L. O programa Estat foi usado para análise dos dados, realizando-se transformação do tipo arc seno $\{\sqrt{ }[(\mathrm{x}+\alpha) / 100]\}$ para variáveis medidas em termos percentuais. 


\subsubsection{Dados biométricos coletados}

Foram coletados os seguintes dados biométricos: porcentagem de emergência 7, 14, 21, 28, 35, 42, 49 e 56 dias após o plantio; altura (cm) mensal de plantas a partir de 60 dias após o plantio até, medidos com trena; diâmetro $(\mathrm{cm})$ do caule a $35 \mathrm{~cm}$ do colo da planta, medido com paquímetro digital 240 dias após plantio. Inicialmente, previu-se a coleta mensal desta variável, contudo optou-se por coleta final, pois muitos tratamentos atingiram esta altura quase que no final do experimento; matérias seca e fresca (g) de parte aérea e sistema radicular 240 dias após plantio (emprego de 3 plantas por parcela). As medidas foram obtidas em balança digital, sendo a secagem realizada em estufa do Departamento de Produção Vegetal da USP-ESALQ durante 72 horas a $64^{\circ} \mathrm{C}$; volume $(\mathrm{mL})$ de sistema radicular nove meses após a semeadura, medido por deslocamento de volume de água em proveta graduada; concentração de clorofila nas folhas, medido com clorofilômetro Minolta ${ }^{\circledR}$ Spad-502, nove meses após a semeadura, em folhas do terço superior da copa; comparação dos custos de produção.

\subsection{Produção de mudas de laranja 'Pêra' (Citrus sinensis L.Osbeck) sobre porta- enxertos limão 'Volkameriano' (Citrus volkameriana Pasquale) e citrumelo 'Swingle' (Poncirus trifoliata $x$ Citrus paradisi) através de interenxertia em ambiente protegido}

\subsubsection{Local}

O trabalho foi conduzido em estufa comercial telada para produção de mudas cítricas, localizada no município de Araras, SP, $22^{\circ} 25^{\prime} 15^{\prime}$ ' S e $47^{\circ} 23^{\prime} 03^{\prime}$ W.

\subsubsection{Material vegetal}

Foram avaliados dois porta-enxertos, citrumelo 4475 ou 'Swingle' (Poncirus trifoliata $x$ Citrus paradisi) e limão 'Volkameriano' clone Catânia 2 (Citrus volkameriana Pasquale), ambos utilizados na citricultura paulista atualmente, contudo incompatíveis com a principal cultivar de laranja doce, laranja 'Pêra' (Citrus sinensis L. Osbeck), avaliada neste ensaio também como copa. Até a elaboração da proposta de 
dissertação, em março de 2003, o limão ‘Volkameriano’ ainda era considerado tolerante à MSC, contudo, atualmente já se sabe que também é intolerante à doença, mas aparentemente de forma menos intensa que o limão ‘Cravo' (Fundecitrus, 2004). Mesmo com esta nova informação, optou-se por manter este porta-enxerto dentro do experimento. A fim de produzir mudas viáveis que conjuguem as qualidades destas variedades, utilizaram-se quatro diferentes interenxertos compatíveis tanto com a variedade copa como com os dois porta-enxertos: laranja 'Valência' (Citrus sinensis L. Osbeck), laranja ‘Hamlin’ (Citrus sinensis L. Osbeck), tangerina ‘Cleopatra’ (Citrus reshni Hort. ex Tanaka) e tangerina 'Sunki' (Citrus sunki Hort. ex Tanaka). A utilização de diferentes interenxertos, além de gerar combinações compatíveis, poderia levar a vigor diferenciado na formação das mudas, portanto tempos necessários distintos para a formação das mesmas no viveiro, além de imprimir diferentes qualidades à planta posteriormente no campo, como tamanho de copa, sazonalidade de produção e longevidade da árvore. Como testemunha, nas mudas de laranja 'Pêra' sobre limão ‘Volkameriano’ e citrumelo ‘Swingle’ foram utilizados interenxertos de laranja ‘Pêra'.

\subsubsection{Tratos culturais}

As mudas foram produzidas a partir de porta-enxertos transplantados de tubetes para sacolas plásticas de 4,5L, em 31/10/2003. Empregou-se substrato comercial Rendmax ${ }^{\circledR}$ Citrus, a base de casca de pinus, e com fertilizante de liberação controlada Osmocote ${ }^{\circledR}$ 22-04-08 $\left(2 \mathrm{~kg} \mathrm{~m}^{-3}\right)$ previamente incorporado ao substrato. A fertirrigação foi a mesma descrita para o experimento anterior. Os porta-enxertos apresentavam altura inicial padronizada em cerca de $35 \mathrm{~cm}$. Durante o crescimento dos porta-enxertos, observaram-se sintomas similares aos de deficiência de cobre e morte de ponteiros somente em limão 'Volkameriano'.

Em 04/02/2004 foi feita a enxertia com os interenxertos a cerca de $12 \mathrm{~cm}$ do colo, cerca de três meses após o transplante. O citrumelo 'Swingle' e o limão 'Volkameriano' apresentavam diâmetro médio de, respectivamente, $0,69 \mathrm{~cm}$ e $0,64 \mathrm{~cm}$, no momento da enxertia. A enxertia foi realizada pelo método do T-invertido, recobrindo-se as borbulhas com fitilhos plásticos, os quais foram retirados 14 dias depois. Utilizaram-se 
borbulhas recém coletadas das quatro variedades de interenxertos, fornecidas pelo viveirista. O método de forçamento de enxerto adotado foi o encurvamento do portaenxerto, sendo que a copa encurvada foi mantida até o primeiro fluxo de crescimento do enxerto de laranja 'Pêra'. Não se verificou senescência das folhas dos porta-enxertos.

Em junho de 2004, as mudas iniciaram o terceiro fluxo de crescimento, e se optou por podá-las a cerca de $60 \mathrm{~cm}$ do ponto de enxertia, evitando seu crescimento exagerado. Nove plantas escolhidas ao acaso foram interenxertadas a $15 \mathrm{~cm}$ da primeira enxertia, com borbulhas de laranja 'Pêra', em 01/06/2004, visando-se verificar a possibilidade de enxertar todo o experimento. Em 30/07/2004 o pegamento foi de 88\% dos enxertos, contudo, quase não houve crescimento das borbulhas, provavelmente, devido às baixas temperaturas ocorridas no período.

Em 02/09/2004, foi realizada a enxertia de laranja 'Pêra' a $12 \mathrm{~cm}$ do ponto de interenxertia, e a retirada do fitilho se deu 20 dias depois. A copa do interenxerto (filtro) foi decotada logo após a enxertia, a uma altura de $15 \mathrm{~cm}$, sendo mantidas a copa encurvada do porta-enxerto e folhas do interenxerto até $15 \mathrm{~cm}$ de altura. Estes só foram excluídos quando o enxerto de laranja 'Pêra' concluiu seu primeiro fluxo de crescimento, 60 dias após a última enxertia (7 meses após a interenxertia inicial). Desta maneira buscou-se otimizar o ciclo de produção da muda interenxertada no viveiro. As mudas atingiram ponto de comercialização cerca de 100 dias após a enxertia de laranja 'Pêra', ou seja, totalizando um ciclo de produção de cerca de 17 meses após a semeadura dos porta-enxertos ou 10 meses após a interexentia.

Durante todo o experimento, se verificou ataque de lesmas desfolhando plantas. Seu controle foi feito via iscas lesmicidas, mantendo-se o ataque sob controle. Sempre que se realizou alguma pulverização nas demais bancadas da estufa, também se pulverizou o experimento. Assim, foi submetido esporadicamente à pulverização para controle de pulgões (deltametrina + óleo vegetal) e larva-minadora dos citros (abamectin), seguindo recomendações dos fabricantes. Também foi realizada monda de trevinho (Oxalis spp.) e de outras plantas invasoras no substrato sempre que necessário. 


\subsubsection{Delineamento estatístico}

O delineamento experimental adotado foi esquema fatorial 2 x 5 (porta-enxerto $\mathrm{x}$ interenxerto), perfazendo dez tratamentos em 3 repetições com blocos casualizadas. A parcela experimental foi constituída de 12 plantas, no total 360 mudas. O programa Estat foi usado para análise dos dados coletados, realizando-se transformação do tipo arc seno $\{\sqrt{ }[(\mathrm{x}+\alpha) / 100]\}$ para variáveis medidas em termos percentuais.

\subsubsection{Dados biométricos coletados}

Foram coletados os seguintes dados biométricos: altura $(\mathrm{cm})$ mensal de plantas a partir do transplante até a formação da muda interenxertada, medida com trena e distinguindo-se porta-enxerto, interenxerto e enxerto; percentagem (\%) de pegamento da enxertia e da interenxertia; comprimento $(\mathrm{cm})$ final do enxerto de laranja 'Pêra', medido com trena 'do ponto de enxertia até meristema apical; diâmetro final $(\mathrm{cm})$ do caule do porta-enxerto a $12 \mathrm{~cm}$ do colo, diâmetro final do interenxerto a $5 \mathrm{~cm}$ do ponto inferior de interenxertia e diâmetro final do enxerto a $5 \mathrm{~cm}$ do ponto de enxertia, medidos com paquímetro digital 100 dias após enxertia; percentagem (\%) de ocorrência de borbulhas dormentes e mortas da copa 100 dias após enxertia; matérias fresca e seca (g) de copa do enxerto e do sistema radicular da muda formada (emprego de três plantas por parcela) 100 dias após enxertia. As medidas foram obtidas em balança digital, sendo a secagem realizada em estufa do Departamento de Produção Vegetal da USP-ESALQ durante 72 horas a $64^{\circ} \mathrm{C}$; comparação dos custos de produção. 


\subsection{Produção de estacas de citrumelo 'Swingle' (Poncirus trifoliata $x$ Citrus paradisi) para fins de enxertia no viveiro e subenxertia no campo}

\subsubsection{Local}

O trabalho foi conduzido nas dependências do Departamento de Produção Vegetal da USP-ESALQ, localizado no município de Piracicaba, SP, $22^{\circ} 42^{\prime} 30^{\prime}$ S e $47^{\circ}$ 38’ 00” W. O clima da região é do tipo Cwa, tropical úmido com estiagem no inverno, chuva de verão e com temperatura média, do mês mais quente, superior a $22^{\circ} \mathrm{C}$, e a do mês mais frio não inferior a $16^{\circ} \mathrm{C}$. A estaquia (enraizamento) foi realizada em câmara de nebulização e as estacas transplantadas para sacolas foram mantidas em estufa telada.

\subsubsection{Material vegetal}

Foram avaliadas estacas de citrumelo 4475 ou 'Swingle'(Poncirus trifoliata $x$ Citrus paradisi), porta-enxerto que induz produtividade satisfatória e alta qualidade de frutos, além de tolerância mediana a estiagem e resistência a declínio dos citros, nematóides dos citros e atualmente não afetado pela MSC (Fundecitrus, 2004). O seu emprego como porta-enxerto vem aumentando gradativamente no país à medida que a MSC torna inviável o uso do tradicional limão 'Cravo' e aumenta a área irrigada de pomares paulistas. Por outro lado, não existem matrizes certificadas deste porta-enxerto hábeis para o fornecimento da quantidade de sementes requeridas pelos viveiros atualmente, tornando a técnica de estaquia uma alternativa à produção de porta-enxertos tanto para fins de enxertia e formação de mudas no viveiro como para subenxertia no campo. A estaquia também multiplica o aproveitamento das sementes, pois se podem obter diversas estacas a partir de uma única planta. A variedade copa empregada foi a laranja 'Valência' (Citrus sinensis L. Osbeck), compatível com o citrumelo 4475 e segunda variedade copa de laranja doce em importância econômica em São Paulo (Figueiredo, 1991). As borbulhas empregadas neste experimento foram fornecidas pelo viveirista de Araras e estavam armazenadas a $5^{\circ} \mathrm{C}$ há 10 dias. 


\subsubsection{Tipos de estacas}

Foram avaliados três tipos de estacas quanto à sua maturidade: herbáceas, semilenhosas e lenhosas, retiradas nesta ordem a partir do ápice de plantas com cerca de $80 \mathrm{~cm}$ de altura. Não se retiraram estacas abaixo de $15 \mathrm{~cm}$ do colo da planta. As estacas foram obtidas de plantas com 8 meses de idade, em 31/03/2004. Em 200 plantas, foi realizada enxertia múltipla 12 dias antes, de modo que se enxertaram duas borbulhas por planta, distantes $20 \mathrm{~cm}$ entre si, a partir de $12 \mathrm{~cm}$ do colo da planta. Deste modo, obtiveram-se uma estaca semi-lenhosa enxertada e uma estaca lenhosa enxertada por planta. Utilizou-se borbulhia do tipo T-invertido, mantendo-se o fitilho sobre as borbulhas ainda nas estacas. As estacas herbáceas não permitiram a enxertia, sendo neste caso transplantadas para sacolas plásticas sem enxertia. Somente neste tipo de estaca se manteve um par de folhas cortadas pela metade. De outras 200 plantas se obtiveram as estacas sem enxertos.

Em 31/03/2004, as estacas foram postas para enraizamento em câmara de nebulização, para transplantio 90 dias depois. Com isto, buscou-se, de um lado, acelerar a obtenção de mudas enxertadas em estacas enraizadas (Koller et al., 2000), ou ainda propagar citrumelo 'Swingle' tanto para fins de enxertia ou de subenxertia, conforme o desenvolvimento que as plantas apresentassem.

Todas as estacas foram padronizadas em $12 \mathrm{~cm}$ de comprimento. As estacas herbáceas foram padronizadas com diâmetro médio superior e inferior de, respectivamente, $0,20 \mathrm{~cm}$ e $0,25 \mathrm{~cm}$, enquanto as semi-lenhosas foram padronizadas com diâmetro médio superior e inferior de, respectivamente, $0,25 \mathrm{~cm}$ e $0,35 \mathrm{~cm}$, e as estacas lenhosas com diâmetro médio superior e inferior de, respectivamente, $0,45 \mathrm{~cm}$ e $0,55 \mathrm{~cm}$.

As plantas que sofreram a poda para fornecer as estacas foram mantidas em sacolas em estufa telada, de modo a se comparar o desenvolvimento das estacas com as plantas podadas. Também se enxertou laranja 'Valência' em parte destas plantas para efeito de comparação. 


\subsubsection{Fitorreguladores}

Foi empregado como fitorregulador promotor de enraizamento o ácido indolbutírico (IBA), dissolvido primeiramente em $\mathrm{KOH}$ e depois diluído em água, nas concentrações $500 \mathrm{mg} \mathrm{L}^{-1}$ e $0 \mathrm{mg} \mathrm{L}^{-1}$. Realizou-se imersão das estacas na solução por 10 segundos antes de colocá-las para enraizar (Santos et al., 1987; Villas-Bôas et al., 1987).

\subsubsection{Tratos culturais}

A nebulização seguiu freqüência de um minuto intercalado a 15 minutos sem funcionamento. As estacas foram colocadas em bandejas de isopor com 72 células, contendo substrato comercial a base de casca de pinus decomposta (Plantamax ${ }^{\circledR}$ Citrus), com fertilizante de liberação controlada Osmocote ${ }^{\circledR}$ 19-06-10 previamente incorporado na concentração de $1 \mathrm{~kg} \mathrm{~m}^{-3}$.

Trinta dias após a instalação, realizou-se desbrota nas estacas, de modo a deixar apenas um broto por estaca não enxertada e nenhum broto nas já enxertadas, para auxiliar o forçamento das borbulhas. A retirada do fitilho plástico deu-se em 26/04/2003 (34 dias após a enxertia), com os devidos cuidados para não se danificar as estacas.

Cerca de 75 dias após a instalação do ensaio, observavam-se raízes por baixo das bandejas. Em 30/06/2004, noventa dias após a instalação do ensaio, as estacas foram retiradas das bandejas, avaliadas e, no caso das que enraizaram satisfatoriamente, transferidas para sacolas plásticas de 4,5L e conduzidas normalmente para fins de enxertia ou subenxertia, em estufa telada. Os tratos culturais empregados foram os mesmos descritos anteriormente, à exceção da fertirrigação, que não foi utilizada. No momento do transplantio, recobriu-se o substrato com uma camada de vermiculita, de modo a manter a umidade do substrato e reduzir o estresse das estacas transplantadas. Em agosto de 2004, foi realizada adubação de cobertura nas mudas, com fertilizante de liberação lenta Osmocote ${ }^{\circledR} 22-4-8$ na dose de $1 \mathrm{~kg} \mathrm{~m}^{-3}$.

Não foi realizada enxertia nos porta-enxertos após seu transplante, pois, não atingiram, até janeiro de 2005, padrão satisfatório para tal, conforme legislação adotada no Estado de São Paulo (Panzani et al., 1994). Desta forma, procedeu-se à análise final das plantas sete meses após seu transplante das bandejas para sacolas de 4,5L. 


\subsubsection{Delineamento estatístico}

O delineamento experimental adotado foi o esquema fatorial 2 × 2 × 2 (tipo de estaca $\mathrm{x}$ fitorregulador $\mathrm{x}$ presença de enxertia), perfazendo oito tratamentos em quatro repetições com blocos casualizados. Ainda se empregaram dois tratamentos extras (estacas herbáceas com e sem imersão em fitorregulador). A parcela experimental foi constituída de dez estacas, no total 400 estacas.

O delineamento experimental adotado após o transplante foi o do tipo blocos casualizados, perfazendo nove tratamentos em três repetições com quatro plantas por parcela, totalizando 108 plantas. Os tratamentos corresponderam, respectivamente: T1mudas formadas a partir de estacas do tipo herbácea enraizadas com IBA 0mg L ${ }^{-1}$; T2mudas formadas a partir de estacas do tipo herbácea enraizadas com IBA 500 $\mathrm{mg} \mathrm{L}^{-1}$; T3- mudas formadas a partir de estacas do tipo lenhosa enraizadas com IBA 0mg L ${ }^{-1} \mathrm{e}$ enxertadas antes do enraizamento; T4- mudas formadas a partir de estacas do tipo lenhosa enraizadas com IBA 500 $\mathrm{mg} \mathrm{L}^{-1}$ e enxertadas antes do enraizamento; T5- mudas formadas a partir de estacas do tipo lenhosa enraizadas com IBA $0 \mathrm{mg} \mathrm{L}^{-1}$; T6- mudas formadas a partir de estacas do tipo lenhosa enraizadas com IBA 500mg L ${ }^{-1}$; $\mathrm{T} 7$ - mudas formadas a partir de estacas do tipo semi-lenhosa enraizadas com IBA $0 \mathrm{mg} \mathrm{L}^{-1}$; T8mudas formadas a partir de estacas do tipo semi-lenhosa enraizadas com IBA 500mg L' 1; T9- mudas formadas a partir dos porta-enxertos que inicialmente forneceram as estacas deste ensaio, a título de testemunha, e previamente enxertadas. O programa Estat foi usado para análise dos dados coletados, realizando-se transformação do tipo arc seno $\{\sqrt{ }[(\mathrm{x}+\alpha) / 100]\}$ para variáveis medidas em termos percentuais.

\subsubsection{Dados biométricos coletados}

Foram coletados os seguintes dados biométricos: porcentagem de estacas vivas, brotadas e enraizadas 90 dias após plantio das estacas; percentagem de pegamento e crescimento de enxertos 90 dias após plantio das estacas; número de raízes principais e comprimento da maior raiz 90 dias após plantio das estacas; comprimento $(\mathrm{cm})$ inicial e final de enxerto e mudas transplantadas, medido com trena sete meses após transplante; diâmetro (mm) final das mudas sete meses após transplante, medido com paquímetro 
digital $5 \mathrm{~cm}$ acima do ponto de enxertia, no caso das estacas previamente enxertadas, ou 5cm acima da brotação inicial, no caso das estacas não enxertadas. matéria seca (g) de parte aérea e sistema radicular das mudas prontas (emprego de três plantas por parcela) sete meses após transplante. As medidas foram obtidas em balança digital, sendo a secagem realizada em estufa do Departamento de Produção Vegetal da USP-ESALQ durante 72 horas a $64^{\circ} \mathrm{C}$; volume $(\mathrm{mL})$ de sistema radicular das mudas prontas, medido por deslocamento de volume de água em proveta graduada sete meses após transplante; comparação dos custos de produção. 


\section{RESULTADOS E DISCUSSÃO}

\subsection{Desenvolvimento de onze porta-enxertos cítricos para fins de subenxertia em diferentes recipientes em cultivo protegido}

Ocorreram duas semeaduras, em julho de 2003 e outubro de 2003. São apresentados os dados referentes à segunda semeadura, por se tratar do mesmo ensaio que originou os demais dados apresentados. Até 14 dias após a semeadura, a emergência foi maior nos tubetes de $75 \mathrm{~mL}$ (Tabela 1). Neste sistema, verificou-se que as sementes ficaram mais superficiais, enquanto que nos outros dois sistemas (tubetes de 290mL e sacolas de 1,7L) notou-se que as sementes afundaram no substrato, o qual é mais grosseiro, e isto deve explicar o atraso inicial na emergência. Contudo, a partir de 21 dias após a semeadura e até dois meses após a semeadura (Tabelas 1 e 2), a emergência nos tubetes de $75 \mathrm{~mL}$ passou a ser menor que as demais. Provavelmente houve maior perda de sementes justamente por estar mais superficiais e assim mais sujeitas à desidratação.

Poncirus trifoliata 'Davis A' e 'Barnes' foram os primeiros a emergir (Tabela 1). Porém, logo aos 14 dias após a semeadura, com cerca de 90 \% de emergência, tangerina 'Sunki’ e citrumelo ‘Swingle’ já se igualavam aos trifoliatas. Um mês após a semeadura, porém, todos os porta-enxertos já superavam 90\% de emergência, com exceção do limão 'Volkameriano', com 69,79\%. Mesmo na contagem final, dois meses após a semeadura, este porta-enxerto não atingiu emergência maior que 83,33\% (Tabela 
2). Tangerina 'Sunki' e Poncirus trifoliata 'Davis A' foram os únicos porta-enxertos com $100 \%$ de emergência.

Plantas produzidas em sacolas de 1,7L atingiram as maiores alturas, de 60 a 240 dias após a semeadura (Tabelas 3 a 5). Até 90 dias após a semeadura, plantas semeadas em tubetes de $290 \mathrm{~mL}$ atingiam a segunda maior altura, sendo que a partir de 120 dias após a semeadura foram superadas pelas plantas transplantadas de tubetes de $75 \mathrm{~mL}$ para sacolas de 1,7 e 4,5L. O transplante ocorreu entre 90 e 120 dias após a semeadura. Isto indica que houve proporcionalidade direta entre o volume de substrato e o crescimento dos porta-enxertos cítricos e, posteriormente, das mudas cítricas, conforme observado por Girardi et al. (2001a).

Trifoliata 'Davis A' atingiu maior altura logo aos 60 dias após a semeadura (Tabela 3). Este porta-enxerto esteve entre os maiores até 150 dias após a semeadura, indicando vigor inicial, tal qual trifoliata 'Barnes' e citrumelo 'Swingle' (Tabela 4). Entretanto, a partir daí, 'Davis A' apresentou crescimento menos intenso de modo que 240 dias após a semeadura atingia apenas 49,20cm de altura em média, contra 93,35cm do limão 'Rugoso', o maior porta-enxerto (Tabela 5). Trifoliata 'Barnes' superou em $15 \mathrm{~cm}$ o trifoliata 'Davis A' 240 dias após a semeadura (Tabelas 4 e 5). Notou-se que trifoliata 'Barnes' apresentou vigor mais acentuado nos últimos meses de avaliação do ensaio. Este comportamento confirma que os trifoliatas e seus híbridos apresentam crescimento vigoroso, porém, após a enxertia com variedades de outros gêneros da família Rutaceae, este vigor em geral tende a desaparecer (Pompeu Jr., 1991).

Laranja 'Caipira' e tangerina 'Sun Shu Sha Kat' apresentaram menores alturas ao longo do experimento, enquanto que os porta-enxertos mais vigorosos foram, em ordem decrescente, limão ‘Rugoso’, limão 'Volkameriano’ e limão ‘Cravo’ (Tabelas 3 a 5). 'Sunki Fruto Grande’ apresentou excelente crescimento, superior ao de 'Sunki' comum e de tangerina 'Sun Shu Sha Kat' 240 dias após a semeadura (Tabela 5).

Notou-se que, considerando-se apenas o sistema de semeadura em tubetes de 290mL, todos os porta-enxertos se equivaleram em altura a partir de 150 dias após a semeadura, o mesmo ocorrendo para as demais variáveis avaliadas (Tabelas 4 a 7). O menor volume do recipiente, provavelmente, limita os porta-enxertos até um máximo 
crescimento possível de ser atingido nesta circunstância, a partir do qual há pouco desenvolvimento, independentemente da espécie ou variedade cítrica. Em recipientes de maior volume, os porta-enxertos puderam crescer mais e assim as diferenças entre seus hábitos de crescimento continuaram.

Oito meses após a semeadura, observou-se que plantas produzidas em sacolas de 1,7L atingiram maior diâmetro a $35 \mathrm{~cm}$ do colo, seguidas de porta-enxertos transplantados para sacolas de 4,5L, porta-enxertos transplantados para sacolas de 1,7L e, finalmente, porta-enxertos semeados em tubetes de 290mL (Tabela 5). Novamente, limão 'Rugoso’ apresentou maior diâmetro, seguido de limão 'Volkameriano', limão 'Cravo' e citrumelo 'Swingle'. Laranja 'Caipira' e as tangerinas apresentaram os menores diâmetros.

A exceção de limão 'Rugoso', com 6,2mm, nenhum outro porta-enxerto apresentou diâmetro maior que 5,0mm, medida considerada mínima para fins de subenxertia (Tersi et al., 2003). Desta forma, nenhuma outra planta estaria apta à subenxertia no campo 240 dias após a semeadura. Na realidade, tem se observado sucesso do uso comercial de subenxertos bem menores do que esta recomendação, muitas vezes plantas de apenas dois a três meses cultivados em tubetes de $75 \mathrm{~mL}$. Isto ocorre conforme a situação específica no campo, sendo que quanto mais velha ou doente for a planta a se subenxertar, recomenda-se subenxertar com maior número de subenxertos ou usar subenxertos mais vigorosos ${ }^{3}$. A altura de $35 \mathrm{~cm}$, que permite a subenxertia acima do ponto de inserção da copa no porta-enxerto que se deseja substituir, acaba sendo o principal parâmetro usado no momento para se considerar a operação de subenxertia. Assim, neste caso, observa-se que todas as plantas produzidas no experimento estariam aptas à subenxertia, sendo que a maioria atingiu esta altura de 120 a 180 dias após a semeadura (Tabelas 3 e 4). Porém, porta-enxertos produzidos em sacolas de $1,7 \mathrm{~L}$ foram os primeiros a atingir $35 \mathrm{~cm}$ de altura, como trifoliata 'Davis A' logo a 90 dias após a semeadura e trifoliata 'Barnes', limão ‘Cravo', citrumelo 'Swingle' e limão ‘Rugoso’ trinta dias depois. Tangerinas ‘Sunki’ e ‘Cleópatra’ só atingiram 35cm

\footnotetext{
${ }^{3}$ TOZATTI, G. Comunicação pessoal, 2005.
} 
de altura em sacolas de 1,7L a 150 dias após a semeadura. O transplante para sacolas de 4,5L acelera o crescimento das plantas, mas não é apropriado para fins de subenxertia devido ao seu alto custo, o que indica que o sistema de semear diretamente em sacolas de 1,7L é o que permite obtenção mais rápida da maioria dos porta-enxertos em condições mínimas para subenxertia no campo.

O crescimento do subenxerto foi proporcional ao volume do recipiente, levando a maiores matérias fresca e seca de sistema radicular 240 dias após a semeadura (Tabela 6). Essas variáveis foram idênticas para todos os subenxertos produzidos em tubetes de 290mL. Tangerinas 'Sunki', 'Sun Shu Sha Kat' e 'Sunki Fruto Grande', laranja 'Caipira'e trifoliatas 'Davis A' e 'Barnes' apresentaram mesmas matérias secas, independentemente do sistema de produção. Isto decorre, provavelmente, do menor vigor de crescimento destas variedades, como se pode constatar pelo fato de que estes mesmos porta-enxertos, a exceção dos dois trifoliatas, apresentaram as menores matérias frescas de sistema radicular. Limões ‘Rugoso' e ‘Cravo’ atingiram as maiores matérias secas de sistema radicular. Estas observações condizem com trabalhos que descrevem o sistema radicular de porta-enxertos cítricos em viveiros de campo na Flórida (Castle, 1977). As mesmas considerações feitas para matérias frescas e secas de sistema radicular são válidas para a parte aérea, com evidente superioridade dos três limões avaliados, sendo limão ‘Rugoso’ o mais vigoroso de todos.

Subenxertos produzidos diretamente em sacolas de 1,7L ou transplantados de tubetes de $75 \mathrm{~mL}$ para sacolas de 4,5L apresentaram maior concentração de clorofila nas folhas em relação aos subenxertos produzidos em tubetes de 290mL, 270 dias após semeadura (Tabela 8). A limitação de volume está diretamente vinculada ao desenvolvimento vegetativo adequado de mudas cítricas (Rezende et al., 1995). Como o tubete limitou o espaço físico e disponibilidade de nutrientes às plantas, reduzindo seu porte, constatou-se início de deficiência nutricional nas plantas deste sistema de produção, sendo esta manifestada pelo amarelecimento inicial das folhas logo aos 180 dias após a semeadura. A leitura do clorofilômetro utiliza a correlação entre coloração de tecido e concentração de clorofila nas folhas para ser um indicativo do estado nutricional 
da planta, em especial ao que se refere a concentração de nitrogênio, por ser elemento integrante da molécula de clorofila (Fox et al., 1994).

Os subenxertos que atingiram as maiores concentrações de clorofila nas folhas foram trifoliata 'Davis A', laranja 'Caipira' e trifoliata 'Barnes', seguidos pelo citrumelo 'Swingle' em situação intermediária (Tabela 8). Tangerinas e limões apresentaram concentrações inferiores, com limões 'Volkameriano' e 'Rugoso' apresentando as menores concentrações. Por outro lado, limões e tangerinas apresentaram, em geral, maior crescimento vegetativo de que $P$. trifoliata e laranja 'Caipira', este último o portaenxerto menos vigoroso. Embora possa parecer um contra-senso que subenxertos menos desenvolvidos apresentem maior concentração de clorofila nas folhas, e, consequentemente, concentração mais equilibrada de nitrogênio, na verdade deve ter ocorrido um efeito decorrente do hábito de crescimento de limões e tangerinas, no mesmo período. Justamente por ter crescimento mais vigoroso, tais espécies vão demonstrar sinais de deficiência nutricional primeiro por exaurirem o substrato antes e assim sofrerem a influência negativa da limitação de espaço e nutrientes com mais antecedência. Já laranja 'Caipira’ e $P$. trifoliata, com crescimento mais lento, não chegaram a ser limitados pelo tamanho dos recipientes dentro dos 270 dias de período de avaliação, portanto não chegaram ao ponto de ter crescimento limitado pelo recipiente, sem ter sua carência nutricional afetada e sem apresentar sintomas mais intensos de deficiência.

O volume do sistema radicular foi diretamente proporcional ao volume do recipiente utilizado (Tabela 8). Desta forma, sacolas de 4,5L levaram a sistema radicular mais volumoso, seguidas por sacolas de $1,7 \mathrm{~L}$ e por fim tubetes de $290 \mathrm{~mL}$. O transplante ou semeadura direta em sacolas de 1,7L não determinaram diferenças no volume do sistema radicular. Espécies de limões atingiram o maior volume radicular, sendo o limão 'Rugoso’ o mais vigoroso. Tangerinas, trifoliatas e laranja 'Caipira' apresentaram menor volume de sistema radicular, embora não tenha se traduzido em menores concentrações de clorofila nas folhas (Tabela 8).

Independentemente do porta-enxerto, não houve diferenças quanto ao volume de sistema radicular de plantas produzidas em tubetes de 290mL (Tabela 8). Isto ocorreu 
uma vez que o pequeno volume do tubete limitou o volume radicular de todas as espécies a uma faixa de 10 a $15 \mathrm{~mL}$, por provocar poda aérea de radicelas que viessem a se desenvolver. A capacidade do recipiente, por ser diretamente proporcional à disponibilidade de recursos como água e nutrientes à planta, bem como acomodação do sistema radicular, é um fator decisivo para determinar a velocidade de crescimento do porta-enxerto e da muda e indicar a viabilidade técnica-econômica do empreendimento (Girardi et al., 2001a; Rezende et al., 1995).

Em recipientes de 1,7L, as espécies de limão superaram as demais. Somente em sacolas de 4,5L foi possível verificar que os porta-enxertos agruparam-se em classes de volume de sistema radicular, em ordem decrescente: limão 'Rugoso', limão 'Volkameriano', limão ‘Cravo', citrumelo ‘Swingle’ e tangerinas, trifoliata 'Davis A' e laranja 'Caipira'. Desta forma, evidencia-se o hábito de crescimento de sistema radicular destas espécies cítricas (Castle, 1978; Castle, 1977). Com maior disponibilidade de espaço, os limões continuaram a apresentar crescimento de sistema radicular de forma rápida, intensa e vigorosa. As demais espécies, mesmo com mais espaço disponível, ainda não haviam saturado o substrato com radicelas 270 dias após a semeadura, pois têm crescimento mais lento. Este é um indicativo de que o ponto de transplante de limões para o campo deve ser anterior às demais espécies, inclusive para se evitar problemas como enovelamento de raízes ou desequilíbrios nutricionais.

Os porta-enxertos podem ser, pois, divididos em três grupos decrescentes quanto a seu crescimento vegetativo: limões, sendo o 'Rugoso' clone Mazoe o mais vigoroso, tangerinas e citrumelo 'Swingle’ em situação intermediária, e finalmente $P$. trifoliata e laranja 'Caipira', sendo que esta apresentou o menor desenvolvimento entre todos os porta-enxertos. Desta forma, é possível se estabelecer expectativas quanto à formação das mudas e subenxertos em ambiente protegido, independentemente do volume do recipiente, levando-se em conta estes três grupos de porta-enxertos.

Destaca-se também a morfologia do sistema radicular das plantas semeadas diretamente em sacolas de 1,7L, que apresentaram uma raiz pivotante definida e de comprimento correspondente à altura da sacola, ao contrário das plantas transplantadas, 
que apresentaram bifurcação do sistema radicular no ponto de poda aérea do tubete, a cerca de 12cm abaixo do colo (Figura 1).

Sendo assim, a produção de porta-enxertos aptos à subenxertia no campo pode ser realizada a partir tanto de plantas produzidas em tubetes de $75 \mathrm{~mL}$ e posteriormente transplantadas para sacolas de $1,7 \mathrm{~L}$, ou plantas produzidas em tubetes de $290 \mathrm{~mL}$ ou ainda plantas produzidas diretamente em sacolas de 1,7L, sendo que neste último sistema os porta-enxertos atingem ponto ideal de subenxertia em menor tempo, cerca de 100 a 150 dias após a semeadura, além de permitir obter plantas maiores em mesmo espaço de tempo, quando se necessitar de subenxertos mais vigorosos no campo. A decisão sobre qual tipo de subenxerto deve ser usado dependerá de fatores como valor unitário do subenxerto, tamanho e idade da planta a ser subenxertada e disponibilidade de tempo para proceder à subenxertia.

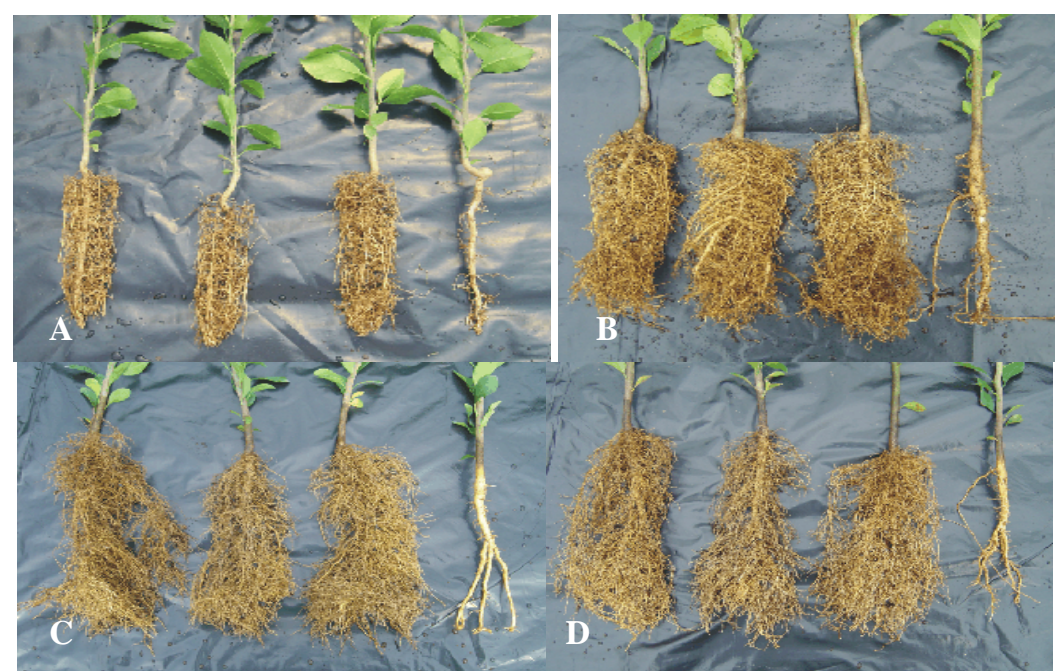

Figura 1 - Sistema radicular de plantas de limão ‘Cravo’: (A) Tubetes de $290 \mathrm{~mL}$, (B) Sacolas de 1,7L, (C) Tubetes de $75 \mathrm{~mL}$ transplantados para sacolas de 1,7L, (D) tubetes de $75 \mathrm{~mL}$ transplantados para sacolas de 4,5L. Piracicaba, 2004 
Tabela 1. Emergência de onze porta-enxertos 7, 14, 21 e 28 dias após a semeadura em recipientes de diferentes volumes. Piracicaba, 2003

\begin{tabular}{|c|c|c|c|c|c|c|c|c|c|c|c|c|}
\hline Container & Cravo & Swingle & Cleópatra & Sunki & $\begin{array}{l}\text { Volka- } \\
\text { meriano }\end{array}$ & Caipira & Rugoso & Davis A & Barnes & $\begin{array}{l}\text { Sun Shu } \\
\text { Sha Kat }\end{array}$ & $\begin{array}{c}\text { Sunki } \\
2506\end{array}$ & Média \\
\hline Emergência & & & & & & $(\%)$ & & & & & & \\
\hline \multicolumn{13}{|l|}{7 DAS } \\
\hline tubete $75 \mathrm{~mL}$ & $0,00 \mathrm{Af}$ & 4,69Aс & 4,69Aс & $1,56 \mathrm{Ae}$ & $0,00 \mathrm{Af}$ & $0,00 \mathrm{Af}$ & $0,00 \mathrm{Af}$ & $18,75 \mathrm{Ab}$ & 20,31Aa & 3,13Ad & $0,00 \mathrm{Af}$ & $4,83 A$ \\
\hline tubete $290 \mathrm{~mL}$ & 0,00Aa & 0,00Ba & 0,00Ba & $0,00 \mathrm{Ba}$ & 0,00Aa & 0,00Aa & 0,00Aа & 0,00Ba & 0,00Ba & 0,00Ba & 0,00Ba & $0,00 B$ \\
\hline sacola $1,7 \mathrm{~L}$ & 0,00Aa & 0,00Ba & 0,00Ba & $0,00 \mathrm{Ba}$ & 0,00Aa & 0,00Aa & 0,00Aa & 0,00Ba & 0,00Ba & 0,00Ba & 0,00Ba & $0,00 B$ \\
\hline \multicolumn{13}{|l|}{14 DAS } \\
\hline tubete $75 \mathrm{~mL}$ & $21,88 \mathrm{Ac}$ & 85,94Aab & $10,94 \mathrm{Ac}$ & $100,00 \mathrm{Aa}$ & $0,00 \mathrm{Ac}$ & 7,81Ac & $15,63 \mathrm{Ac}$ & 89,06Aab & 93,75Aab & $15,63 \mathrm{Ac}$ & 9,38Ac & $40,91 A$ \\
\hline tubete $290 \mathrm{~mL}$ & $0,00 \mathrm{Bc}$ & 68,75Bab & $3,13 \mathrm{Bc}$ & 65,63Bab & $0,00 \mathrm{Ac}$ & $0,00 \mathrm{Bc}$ & $6,25 \mathrm{Bc}$ & $46,88 \mathrm{Bb}$ & $75,00 \mathrm{Ba}$ & 3,13Bс & $0,00 \mathrm{Bc}$ & $24,43 B$ \\
\hline sacola $1,7 \mathrm{~L}$ & 3,13Вс & $65,63 \mathrm{Ba}$ & $0,00 \mathrm{Bc}$ & $62,50 \mathrm{Ba}$ & $0,00 \mathrm{Ac}$ & $0,00 \mathrm{Bc}$ & $6,25 \mathrm{Bc}$ & $43,75 \mathrm{Bb}$ & 53,13Cab & 0,00Bc & 3,13Вс & $21,59 B$ \\
\hline \multicolumn{13}{|l|}{21 DAS } \\
\hline tubete $75 \mathrm{~mL}$ & 76,56Abc & 92,19Bab & 92,19ABab & $100,00 \mathrm{Aa}$ & $43,75 \mathrm{Ac}$ & $43,75 \mathrm{Ac}$ & 90,63Bab & 100,00Aa & 98,44 Aа & $75,00 \mathrm{Bbc}$ & 67,19Bbc & $79,97 B$ \\
\hline tubete $290 \mathrm{~mL}$ & $68,75 \mathrm{Ac}$ & 100,00Aa & $75,00 \mathrm{Bc}$ & $100,00 \mathrm{Aa}$ & $25,00 \mathrm{Ad}$ & 34,38Ad & $100,00 \mathrm{Aa}$ & 96,88Aab & 100,00Aa & 90,63Aabc & $81,25 \mathrm{ABbc}$ & $79,26 B$ \\
\hline sacola $1,7 \mathrm{~L}$ & $81,25 \mathrm{Ab}$ & 100,00Aa & 96,88Aab & $100,00 \mathrm{Aa}$ & 40,63Ac & $31,25 \mathrm{Ac}$ & 100,00Aa & 100,00Aa & 100,00Aa & 96,88Aab & 87,50Aab & $84,94 A$ \\
\hline \multicolumn{13}{|l|}{28 DAS } \\
\hline tubete $75 \mathrm{~mL}$ & 84,38Bcde & 95,31Babc & 100,00Aa & $100,00 \mathrm{Aa}$ & 71,88Ae & 85,94Bcde & 92,19Bbcd & 100,00Aa & $98,44 \mathrm{Aab}$ & 82,81Bde & 82,81Bde & $90,34 C$ \\
\hline tubete $290 \mathrm{~mL}$ & $87,50 \mathrm{Bb}$ & 100,00Aa & 96,88Aa & $100,00 \mathrm{Aa}$ & 65,63Аса & 93,75Aab & 100,00Aa & 100,00Aa & 100,00 Aа & 100,00Aa & 100,00Аа & $94,89 B$ \\
\hline $\begin{array}{c}\text { sacola } 1,7 \mathrm{~L} \\
\text { Média Porta- } \\
\text { enxertos }\end{array}$ & $100,00 \mathrm{Aa}$ & $100,00 \mathrm{Aa}$ & $100,00 \mathrm{Aa}$ & $100,00 \mathrm{Aa}$ & $71,88 \mathrm{Ab}$ & 96,88Aa & $100,00 \mathrm{Aa}$ & 100,00 Aа & 100,00 Aа & $100,00 \mathrm{Aa}$ & 100,00Aa & $97,16 A$ \\
\hline $28 D A S$ & $90,63 d$ & $98,44 a b$ & $98,96 a b$ & $100,00 a$ & $69,79 e$ & $92,19 c d$ & $97,40 a b c$ & $100,00 a$ & $99,48 a b$ & $94,27 b c d$ & $94,27 b c d$ & \\
\hline
\end{tabular}


Tabela 2. Emergência de onze porta-enxertos 35, 42, 49 e 56 dias após a semeadura em recipientes de diferentes volumes. Piracicaba, 2003

\begin{tabular}{|c|c|c|c|c|c|c|c|c|c|c|c|c|}
\hline \multirow[b]{2}{*}{ Container } & \multicolumn{12}{|c|}{ Porta - Enxerto } \\
\hline & Cravo & Swingle & Cleópatra & Sunki & $\begin{array}{l}\text { Volka- } \\
\text { meriano }\end{array}$ & Caipira & Rugoso & Davis A & Barnes & $\begin{array}{l}\text { Sun Shu } \\
\text { Sha Kat }\end{array}$ & $\begin{array}{c}\text { Sunki } \\
2506\end{array}$ & Média \\
\hline Emergência & & & & & & $(\%)$ & & & & & & \\
\hline \multicolumn{13}{|l|}{35 DAS } \\
\hline tubete $75 \mathrm{~mL}$ & 87,50Bcde & 95,31Babc & $100,00 \mathrm{Aa}$ & $100,00 \mathrm{Aa}$ & 75,00Be & 93,75Bbcd & 92,19Bbcd & $100,00 \mathrm{Aa}$ & $98,44 \mathrm{Aab}$ & 82,81Bde & 82,81Bde & $91,62 B$ \\
\hline tubete $290 \mathrm{~mL}$ & $90,63 \mathrm{Bb}$ & 100,00Aa & 96,88Aab & $100,00 \mathrm{Aa}$ & $90,63 \mathrm{Ab}$ & 93,75Bab & 100,00Aa & $100,00 \mathrm{Aa}$ & $100,00 \mathrm{Aa}$ & $100,00 \mathrm{Aa}$ & $100,00 \mathrm{Aa}$ & $97,44 A$ \\
\hline sacola $1,7 \mathrm{~L}$ & 100,00Aa & $100,00 \mathrm{Aa}$ & $100,00 \mathrm{Aa}$ & $100,00 \mathrm{Aa}$ & $78,13 \mathrm{ABb}$ & $100,00 \mathrm{Aa}$ & $100,00 \mathrm{Aa}$ & $100,00 \mathrm{Aa}$ & $100,00 \mathrm{Aa}$ & $100,00 \mathrm{Aa}$ & $100,00 \mathrm{Aa}$ & $98,01 A$ \\
\hline \multicolumn{13}{|l|}{42 DAS } \\
\hline tubete $75 \mathrm{~mL}$ & 92,19Bbc & 95,31Bab & $100,00 \mathrm{Aa}$ & $100,00 \mathrm{Aa}$ & 75,00Bd & 93,75Bbc & 92,19Bbc & $100,00 \mathrm{Aa}$ & $98,44 \mathrm{Aab}$ & $82,81 \mathrm{Bcd}$ & $82,81 \mathrm{Bcd}$ & $92,05 B$ \\
\hline tubete $290 \mathrm{~mL}$ & $90,63 \mathrm{Bb}$ & 100,00Aa & 96,88Aab & $100,00 \mathrm{Aa}$ & 90,63Ab & 96,88Aab & $100,00 \mathrm{Aa}$ & $100,00 \mathrm{Aa}$ & $100,00 \mathrm{Aa}$ & $100,00 \mathrm{Aa}$ & $100,00 \mathrm{Aa}$ & $97,73 A$ \\
\hline sacola $1,7 \mathrm{~L}$ & 100,00Aa & 100,00Aa & 100,00Aa & $100,00 \mathrm{Aa}$ & $78,13 \mathrm{Bb}$ & $100,00 \mathrm{Aa}$ & $100,00 \mathrm{Aa}$ & $100,00 \mathrm{Aa}$ & $100,00 \mathrm{Aa}$ & $100,00 \mathrm{Aa}$ & $100,00 \mathrm{Aa}$ & $98,01 A$ \\
\hline \multicolumn{13}{|l|}{49 DAS } \\
\hline tubete $75 \mathrm{~mL}$ & $93,75 \mathrm{Bbc}$ & 96,88Bab & $100,00 \mathrm{Aa}$ & $100,00 \mathrm{Aa}$ & 78,13Bd & 93,75Bbc & 92,19Bbc & $100,00 \mathrm{Aa}$ & $98,44 \mathrm{Aab}$ & $82,81 \mathrm{Bcd}$ & $82,81 \mathrm{Bcd}$ & $92,61 B$ \\
\hline tubete $290 \mathrm{~mL}$ & $93,75 \mathrm{Ba}$ & 100,00Aa & 96,88 Aа & $100,00 \mathrm{Aa}$ & 93,75Aa & 96,88Аa & $100,00 \mathrm{Aa}$ & $100,00 \mathrm{Aa}$ & $100,00 \mathrm{Aa}$ & $100,00 \mathrm{Aa}$ & $100,00 \mathrm{Aa}$ & $98,30 A$ \\
\hline sacola $1,7 \mathrm{~L}$ & 100,00Aa & 100,00Aa & $100,00 \mathrm{Aa}$ & $100,00 \mathrm{Aa}$ & $78,13 \mathrm{Bb}$ & $100,00 \mathrm{Aa}$ & $100,00 \mathrm{Aa}$ & $100,00 \mathrm{Aa}$ & $100,00 \mathrm{Aa}$ & $100,00 \mathrm{Aa}$ & $100,00 \mathrm{Aa}$ & $98,01 A$ \\
\hline \multicolumn{13}{|l|}{56 DAS } \\
\hline tubete $75 \mathrm{~mL}$ & 96,88Bab & 96,88Bab & $100,00 \mathrm{Aa}$ & $100,00 \mathrm{Aa}$ & 78,13Be & 93,75Bbc & 92,19Bbc & $100,00 \mathrm{Aa}$ & $98,44 \mathrm{Aab}$ & $82,81 \mathrm{Bcd}$ & $82,81 \mathrm{Bcd}$ & $92,90 B$ \\
\hline tubete $290 \mathrm{~mL}$ & $93,75 \mathrm{Ba}$ & 100,00Aa & 96,88 Aа & $100,00 \mathrm{Aa}$ & 93,75Aa & 96,88Аa & $100,00 \mathrm{Aa}$ & $100,00 \mathrm{Aa}$ & $100,00 \mathrm{Aa}$ & $100,00 \mathrm{Aa}$ & $100,00 \mathrm{Aa}$ & $98,30 A$ \\
\hline sacola $1,7 \mathrm{~L}$ & 100,00Aa & 100,00Aa & $100,00 \mathrm{Aa}$ & $100,00 \mathrm{Aa}$ & $78,13 \mathrm{Bb}$ & $100,00 \mathrm{Aa}$ & $100,00 \mathrm{Aa}$ & $100,00 \mathrm{Aa}$ & $100,00 \mathrm{Aa}$ & $100,00 \mathrm{Aa}$ & $100,00 \mathrm{Aa}$ & $98,01 A$ \\
\hline $\begin{array}{l}\text { Média Porta- } \\
\text { enxertos } \\
56 \text { DAS }\end{array}$ & $96,88 a b$ & $98,96 a b$ & $98,96 a b$ & $100,00 a$ & $83,33 c$ & $96,88 a b$ & $97,40 a b$ & $100,00 a$ & $99,48 a b$ & $94,27 b$ & $94,27 b$ & \\
\hline
\end{tabular}

Médias seguidas por letras maiúsculas e minúsculas diferentes, respectivamente em colunas e linhas, diferem entre si a $5 \%$ de probabilidade pelo Teste de Tukey. 
Tabela 3. Altura de onze porta-enxertos 60, 90 e 120 dias após semeadura em quatro sistemas de produção. Piracicaba, 2004

\begin{tabular}{|c|c|c|c|c|c|c|c|c|c|c|c|c|}
\hline \multirow[b]{2}{*}{ Container } & \multicolumn{12}{|c|}{ Porta - Enxerto } \\
\hline & Cravo & Swingle & Cleópatra & Sunki & Volkameriano & Caipira & Rugoso & Davis A & Barnes & $\begin{array}{c}\text { Sun Shu Sha } \\
\text { Kat }\end{array}$ & Sunki 2506 & Média \\
\hline Altura & & & & & & (cm) & & & & & & \\
\hline \multicolumn{13}{|l|}{60 DAS } \\
\hline A & 6,72Bde & 11,89Bb & 6,10CAe & 7,09Ade & 5,96Ae & 6,28Ade & $8,16 \mathrm{Bcd}$ & $14,22 \mathrm{Ba}$ & $9,30 \mathrm{Bc}$ & 6,41ABde & 6,79ABde & $8,08 B$ \\
\hline B & 8,66Ad & $16,95 \mathrm{Ab}$ & 7,09Adef & 7,00Adef & 5,49Af & 6,48Aef & $11,50 \mathrm{Ac}$ & 19,75 Aа & $11,06 \mathrm{Ac}$ & 7,41Ade & 7,84Adef & $9,93 A$ \\
\hline C & 5,63Bde & $9,67 \mathrm{Cb}$ & 5,70Ade & 5,08Bdef & 4,56ABef & 4,60Bef & 6,85BCcd & $12,21 \mathrm{Ca}$ & 7,86BCbc & 4,82BCdef & $3,45 \mathrm{Cf}$ & $6,40 \mathrm{C}$ \\
\hline $\mathbf{D}$ & 5,16Bde & $9,42 \mathrm{Cb}$ & 5,69Acd & 5,36Bcd & $3,25 \mathrm{Be}$ & 4,92ABde & 6,03Ccd & $11,86 \mathrm{Ca}$ & 7,33Сc & 4,14Cde & 5,28Bde & $6,22 C$ \\
\hline Média & $6,54 d$ & $11,98 b$ & $6,15 d$ & $6,13 d$ & $4,81 e$ & $5,57 d e$ & $8,13 c$ & $14,51 a$ & $8,89 c$ & 5,69de & $5,84 d$ & \\
\hline \multicolumn{13}{|l|}{90 DAS } \\
\hline A & 13,31Bde & $21,06 \mathrm{Bb}$ & 12,25Bde & 14,88ABcde & 11,41Ae & 11,97Ade & 16,41Bbcd & $27,47 \mathrm{Ba}$ & $19,28 \mathrm{Bbc}$ & 12,56ABde & 14,25ABde & $15,89 B$ \\
\hline B & 21,79Ade & $32,94 \mathrm{Ab}$ & 16,38Afg & 17,17Aefg & $12,81 \mathrm{Ag}$ & 13,32Afg & 28,94Abc & 40,77Aa & 26,16Acd & 16,06Afg & 17,63Aef & $22,18 A$ \\
\hline C & 12,75Bcde & $19,42 \mathrm{Bb}$ & 12,23Bde & 11,98Bde & 12,23Ade & 11,62Ae & 17,48Bbc & $25,06 \mathrm{Ba}$ & 16,50Bbcd & 10,50Be & 10,64Be & $14,58 \mathrm{C}$ \\
\hline D & 12,75Bcde & $19,42 \mathrm{Bb}$ & 12,23Bde & 11,98Bde & 12,23Ade & 11,62Ae & $17,48 \mathrm{Bbc}$ & $25,06 \mathrm{Ba}$ & 16,50Bbcd & $10,50 \mathrm{Be}$ & $10,64 \mathrm{Be}$ & $14,58 \mathrm{C}$ \\
\hline Média & $15,15 d$ & $23,21 b$ & $13,27 d e$ & $14,00 \mathrm{de}$ & $12,17 e$ & $12,13 e$ & $20,08 c$ & $29,59 a$ & $19,61 c$ & $12,41 e$ & 13,29de & \\
\hline \multicolumn{13}{|l|}{120 DAS } \\
\hline A & 16,99Bbcd & 23,81Cab & $14,72 \mathrm{Cd}$ & 19,78Bbcd & 13,69Bd & 15,73Bcd & 19,78Cbcd & $29,02 \mathrm{Ca}$ & 22,75Cabc & $15,52 \mathrm{Bcd}$ & 18,31Bbcd & $19,10 \mathrm{C}$ \\
\hline B & $40,83 \mathrm{Ac}$ & $50,16 \mathrm{Ab}$ & 28,45Ade & 30,67Ade & 24,87Ade & $22,88 \mathrm{Ae}$ & 52,31Aab & $58,72 \mathrm{Aa}$ & 51,29Aab & 27,84Ade & $32,31 \mathrm{Ad}$ & $38,21 A$ \\
\hline $\mathbf{C}$ & 18,06Be & 32,13Bab & 21,50Bde & 24,00Bcde & 25,00Abcd & 23,53Acde & 28,81Bbcd & 38,69Ba & 29,69Bbc & 20,50Be & 20,30Be & $25,66 B$ \\
\hline \multirow{2}{*}{$\begin{array}{c}\text { D } \\
\text { Média }\end{array}$} & 32,34Bbcd & 37,97Bab & 25,41Bcde & 28,28Bcde & 32,72Abcd & 29,50Acde & 37,50Bbc & $43,25 \mathrm{Ba}$ & 35,19Bbc & $24,78 \mathrm{Be}$ & $23,03 \mathrm{Be}$ & $31,81 B$ \\
\hline & $37,31 c$ & $43,83 b$ & $30,78 c$ & $33,76 c$ & $33,41 c$ & $28,90 c$ & $48,52 a$ & $47,58 a$ & $44,92 b$ & $29,78 c$ & $31,86 c$ & \\
\hline
\end{tabular}

Médias seguidas por letras maiúsculas e minúsculas diferentes, respectivamente em colunas e linhas, diferem entre si a 5 \% de probabilidade pelo Teste de Tukey.
(A) tubetes de $290 \mathrm{~mL}$
(B) sacolas de $1,7 \mathrm{~L}$
(C) transplante de tubetes de $75 \mathrm{~mL}$ para sacolas de $1,7 \mathrm{~L}$
(D) transplante de tubetes de $75 \mathrm{~mL}$ para sacolas de $4,5 \mathrm{~L}$ 
Tabela 4. Altura de onze porta-enxertos 150, 180 e 210 dias após semeadura em quatro sistemas de produção. Piracicaba, 2004

\begin{tabular}{|c|c|c|c|c|c|c|c|c|c|c|c|c|}
\hline \multirow[b]{2}{*}{ Container } & \multicolumn{12}{|c|}{ Porta - Enxerto } \\
\hline & Cravo & Swingle & Cleópatra & Sunki & Volkameriano & Caipira & Rugoso & Davis A & Barnes & $\begin{array}{c}\text { Sun Shu Sha } \\
\text { Kat }\end{array}$ & Sunki 2506 & Média \\
\hline Altura & & & & & & (cm) & & & & & & \\
\hline \multicolumn{13}{|l|}{150 DAS } \\
\hline $\mathbf{A}$ & $25,69 \mathrm{Ba}$ & $32,72 \mathrm{Ba}$ & $25,47 \mathrm{Ba}$ & $31,75 \mathrm{Ba}$ & $23,75 \mathrm{Ba}$ & $24,66 \mathrm{Aa}$ & $30,53 \mathrm{Ba}$ & 30,63Ca & $33,16 \mathrm{Ba}$ & $24,91 \mathrm{Ba}$ & $28,84 \mathrm{Ba}$ & $28,37 B$ \\
\hline B & 60,77Acde & 66,66Abcd & 46,84Aef & 46,72Aef & 44,44Afg & 31,92Ag & 88,53Аа & 73,19Abc & 76,16Aab & 44,66Afg & 52,53Adef & $57,49 A$ \\
\hline C & 30,44Babc & 37,97Bab & $25,41 \mathrm{Bbc}$ & $28,28 \mathrm{Bbc}$ & 32,72Babc & 29,50Aabc & 37,50Bab & $43,25 \mathrm{Ba}$ & 35,19Babc & $24,78 \mathrm{Bbc}$ & $23,03 \mathrm{Bc}$ & $31,64 B$ \\
\hline D & 32,34Babc & 37,97Bab & $25,41 \mathrm{Bbc}$ & $28,28 \mathrm{Bbc}$ & 32,72Babc & 29,50Aabc & $37,50 \mathrm{Bab}$ & $43,25 B \mathrm{Ba}$ & 35,19Babc & $24,78 \mathrm{Bbc}$ & $23,03 \mathrm{Bc}$ & $31,81 B$ \\
\hline Média & $37,31 b c$ & $43,83 a b$ & $30,78 c d$ & $33,76 c d$ & $33,41 c d$ & $28,90 d$ & $48,52 a$ & $47,58 a$ & $44,92 a$ & $29,78 d$ & $31,86 c d$ & \\
\hline \multicolumn{13}{|l|}{180 DAS } \\
\hline A & 33,78Ba & $39,56 \mathrm{Ba}$ & $35,41 \mathrm{Ba}$ & 41,34ABa & $33,44 \mathrm{Ba}$ & 29,63АВа & 39,78Ca & $30,88 \mathrm{Ba}$ & $42,16 \mathrm{Ba}$ & $30,94 \mathrm{Ba}$ & 39,03Ва & $35,99 C$ \\
\hline B & 70,16Acde & 79,09Abc & 59,06Ade & 52,19Aef & 57,69Adef & $38,94 \mathrm{Af}$ & $123,91 \mathrm{Aa}$ & 74,50Abcd & $93,34 \mathrm{Ab}$ & 60,00Acde & 65,00Acde & $70,35 A$ \\
\hline C & 47,75Bab & 43,50Bab & $33,38 \mathrm{Bb}$ & $35,09 \mathrm{Bb}$ & 48,00ABab & 37,34Aab & $55,53 \mathrm{Ba}$ & 42,59Bab & 41,53Bab & 37,41Bab & $31,76 \mathrm{Bb}$ & $41,26 B$ \\
\hline D & 46,75Bab & 42,03Bab & $35,00 \mathrm{Bbc}$ & 33,06Bbc & 47,59ABab & $20,88 \mathrm{Bc}$ & $57,53 \mathrm{Ba}$ & 42,64Bab & 48,94Bab & 43,31Bab & $34,94 \mathrm{Bbc}$ & $41,15 B$ \\
\hline Média & $49,61 b c d$ & $51,05 b c$ & $40,71 d e$ & $40,42 d e$ & $46,68 c d$ & $31,70 e$ & $69,19 a$ & $47,65 b c d$ & $56,49 b$ & $42,91 c d$ & $42,68 c d$ & \\
\hline \multicolumn{13}{|l|}{210 DAS } \\
\hline $\mathbf{A}$ & $41,75 \mathrm{Ca}$ & 39,19Ba & 43,69Ba & $44,50 \mathrm{Ba}$ & $39,50 \mathrm{Ca}$ & $34,00 \mathrm{Aa}$ & $42,75 \mathrm{Ca}$ & $34,75 \mathrm{Ba}$ & 41,81Ca & $35,31 \mathrm{Ba}$ & $45,50 \mathrm{Ba}$ & $40,25 D$ \\
\hline B & 90,97Abc & 85,88Abcd & 63,53Adef & 69,83Acde & $90,16 \mathrm{Abc}$ & 42,00Af & 147,31Aa & 74,94Acde & $100,69 \mathrm{Ab}$ & $60,47 \mathrm{Aef}$ & 75,70Acde & $81,95 A$ \\
\hline C & 65,03Bab & 43,69Bbcd & 47,16ABbc & 46,59Bbcd & $64,13 \mathrm{Babc}$ & 39,91Ad & $74,81 \mathrm{Ba}$ & 43,34Bbcd & 44,97Cbcd & 55,59Aabc & 41,66Bcd & $51,53 C$ \\
\hline D & 61,97Bbc & $51,28 \mathrm{Bbc}$ & $62,13 \mathrm{ABbc}$ & 54,81ABbc & 70,38Bab & 27,84Ad & $87,69 \mathrm{Ba}$ & 44,41Bcd & 64,81Babc & 70,63Aab & 46,72Bcd & $58,42 B$ \\
\hline Média & $64,93 b c$ & $55,01 b c d e$ & $54,13 c d e$ & $53,94 c d e$ & $66,04 b$ & $35,94 f$ & $88,14 a$ & $49,36 e$ & $63,07 b c d$ & $55,50 b c d e$ & $52,39 d e$ & \\
\hline
\end{tabular}

Médias seguidas por letras maiúsculas e minúsculas diferentes, respectivamente em colunas e linhas, diferem entre si a 5 \% de probabilidade pelo Teste de Tukey.
(A) tubetes de $290 \mathrm{~mL}$
(B) sacolas de $1,7 \mathrm{~L}$
(C) transplante de tubetes de $75 \mathrm{~mL}$ para sacolas de $1,7 \mathrm{~L}$
(D) transplante de tubetes de $75 \mathrm{~mL}$ para sacolas de $4,5 \mathrm{~L}$ 
Tabela 5. Altura e diâmetro a 35cm do colo de onze porta-enxertos, 240 dias após semeadura em quatro sistemas de produção. Piracicaba, 2004

\begin{tabular}{|c|c|c|c|c|c|c|c|c|c|c|c|c|}
\hline \multirow[b]{2}{*}{$\begin{array}{l}\text { Sistema de } \\
\text { Produção }\end{array}$} & \multicolumn{9}{|c|}{ Porta-enxerto } & \multirow[b]{2}{*}{ Cravo } & \multirow[b]{2}{*}{ Swingle } & \multirow[b]{2}{*}{ Média } \\
\hline & Cravo & Swingle & $\begin{array}{c}\text { Sistema } \\
\text { de } \\
\text { Produção }\end{array}$ & Cravo & Swingle & $\begin{array}{l}\text { Sistema de } \\
\text { Produção }\end{array}$ & Cravo & Swingle & $\begin{array}{l}\text { Sistema de } \\
\text { Produção }\end{array}$ & & & \\
\hline Altura & & & & & & $(\mathrm{cm})$ & & & & & & \\
\hline $\mathbf{A}$ & 43,83Da & 38,92Ca & $44,58 \mathrm{Ba}$ & $45,58 \mathrm{Ca}$ & 41,00Ca & $35,58 \mathrm{Aa}$ & 43,17Da & 41,92Ba & $43,75 \mathrm{Ca}$ & 34,75Ba & 47,75Ca & $41,89 D$ \\
\hline B & $112,42 \mathrm{Ab}$ & 87,25 Acd & 74,17Adef & $64,42 \mathrm{ABf}$ & $116,00 \mathrm{Ab}$ & 46,67Ag & 144,83Aa & 66,92Aef & $94,92 \mathrm{Ac}$ & $60,25 \mathrm{Afg}$ & 79,17Acd & $86,09 A$ \\
\hline C & 65,92Cab & $50,58 \mathrm{Cbc}$ & $57,25 \mathrm{Bbc}$ & $52,17 \mathrm{Bbc}$ & $78,75 \mathrm{Ba}$ & 47,67Ac & 78,08Ca & $44,75 B c$ & 48,83Cc & $53,08 \mathrm{Abc}$ & $61,17 \mathrm{Bbc}$ & $58,02 C$ \\
\hline D & $86,25 B b c$ & 68,83Bde & 72,42Acd & 68,83Ade & $89,83 \mathrm{Bb}$ & $38,17 \mathrm{Af}$ & $107,33 \mathrm{Ba}$ & $43,58 \mathrm{Bf}$ & 78,17Bbc & 61,58Ae & $82,58 \mathrm{Abc}$ & $72,51 D$ \\
\hline Média & $77,10 b$ & $61,40 c d$ & $62,10 c d$ & $57,75 d e$ & $81,40 b$ & $42,02 g$ & $93,35 a$ & $49,29 f g$ & $66,42 c$ & $52,42 e f$ & $67,67 c$ & \\
\hline Diâmetro & & & & & & $(\mathrm{mm})$ & & & & & & \\
\hline A & 2,38Ca & 2,32Ca & $2,06 \mathrm{Ba}$ & $2,47 \mathrm{Ba}$ & 2,18Ca & $2,24 \mathrm{Ba}$ & 2,29Da & $1,57 \mathrm{Ca}$ & 2,37Ca & 2,01Ca & $2,36 \mathrm{Ba}$ & $2,20 D$ \\
\hline B & 6,91Ab & 5,15 Ac & 3,58Ad & 3,90Acd & 7,14Ab & 3,56Ad & 9,38Aa & 3,92Acd & 4,42Acd & 3,48Ad & 4,31Acd & $5,07 A$ \\
\hline C & 4,19Bbc & 3,32BCcd & 2,65Abd & 3,04Abcd & 4,74Bab & 2,59Abd & 5,71Ca & $2,66 \mathrm{Bd}$ & 2,93BCd & 2,85Abd & $2,38 \mathrm{Bd}$ & $3,37 C$ \\
\hline D & 4,98Bbc & 4,03Bcd & 3,14Ade & 3,52Abd & $5,75 \mathrm{Bb}$ & 2,17Be & $7,30 \mathrm{Ba}$ & 2,88Abde & 3,70Abd & 3,36Ade & 2,80Bde & $3,97 B$ \\
\hline Média & $4,62 b$ & $3,71 c$ & 2,86de & 3,23cde & $4,95 b$ & $2,64 e$ & $6,17 a$ & 2,76de & $3,36 c d$ & 2,93de & 2,96de & \\
\hline
\end{tabular}

Médias seguidas por letras maiúsculas e minúsculas diferentes, respectivamente em colunas e linhas, diferem entre si a 5 \% de probabilidade pelo Teste de Tukey.
(A) tubetes de $290 \mathrm{~mL}$
(B) sacolas de 1,7L
(C) transplante de tubetes de $75 \mathrm{~mL}$ para sacolas de $1,7 \mathrm{~L}$
(D) transplante de tubetes de $75 \mathrm{~mL}$ para sacolas de $4,5 \mathrm{~L}$ 
Tabela 6. Matéria fresca de sistema radicular (MFR) e matéria seca de sistema radicular (MSR) de onze porta-enxertos, 240 dias após semeadura em quatro sistemas de produção. Piracicaba, 2004

\begin{tabular}{|c|c|c|c|c|c|c|c|c|c|c|c|c|}
\hline $\begin{array}{c}\text { Sistema de } \\
\text { Produção }\end{array}$ & Cravo & Swingle & $\begin{array}{c}\text { Sistema de } \\
\text { Produção }\end{array}$ & Cravo & Swingle & $\begin{array}{l}\text { orta-enxerto } \\
\text { Sistema } \\
\text { de } \\
\text { Produção }\end{array}$ & $\begin{array}{l}\text { o } \\
\text { Cravo }\end{array}$ & Swingle & $\begin{array}{c}\text { Sistema de } \\
\text { Produção }\end{array}$ & Cravo & Swingle & Média \\
\hline MFR & & & & & & (g) & & & & & & \\
\hline A & 11,94Da & $12,40 \mathrm{Ca}$ & 7,23Ba & $11,06 \mathrm{Aa}$ & $12,81 \mathrm{Ca}$ & $11,33 \mathrm{Aa}$ & $15,69 \mathrm{Da}$ & $10,84 \mathrm{Ba}$ & $12,46 \mathrm{Ba}$ & $11,47 \mathrm{Aa}$ & 7,94Ba & $11,38 C$ \\
\hline B & 60,44Bab & 42,80Abcd & 21,05Ae & 24,76Acde & 43,17Abbc & 23,30Ade & $80,12 \mathrm{Ba}$ & 31,61Acde & 35,66Acde & 20,90Ae & 20,11Abe & $36,72 A$ \\
\hline C & 32,65Cab & 26,36Всаbc & 12,84 Acd & 14,12Abcd & 29,15Babc & 11,59Acd & 44,88Ca & $7,20 \mathrm{Bd}$ & 14,08Bbcd & 13,82Abcd & $12,46 \mathrm{Abcd}$ & $19,92 B$ \\
\hline D & 77,32Ab & 40,95Abcd & 17,20Ae & 21,03Ae & $46,30 \mathrm{Ac}$ & $14,07 \mathrm{Ae}$ & 115,7Аa & 33,75Acde & 32,90Acde & 25,88Ade & 28,11Acde & $41,20 A$ \\
\hline Média & $45,59 c$ & $30,62 c d$ & $14,58 e$ & $17,74 e$ & $32,86 b$ & $15,07 e$ & $64,10 a$ & $20,85 d e$ & $23,77 c d e$ & $18,02 e$ & $17,15 e$ & \\
\hline MSR & & & & & & (g) & & & & & & \\
\hline $\mathbf{A}$ & $5,04 \mathrm{Ba}$ & $4,94 \mathrm{Ba}$ & $2,49 B \mathrm{Ba}$ & $4,25 \mathrm{Aa}$ & $5,74 \mathrm{Ba}$ & 4,19Аа & 7,36Ca & 3,81Aa & 4,78Aa & 4,44Aa & 2,92Aa & $4,54 B$ \\
\hline B & 24,54Aab & 15,99Aab & $10,82 \mathrm{Ab}$ & 7,58Ab & 15,65Aab & $7,40 \mathrm{Ab}$ & 32,4Aba & $9,98 \mathrm{Ab}$ & 13,39Aab & $6,23 \mathrm{Ab}$ & $6,50 \mathrm{Ab}$ & $13,69 A$ \\
\hline C & 13,01Aa & 8,85Abab & 12,90Bab & $3,50 \mathrm{Ab}$ & 9,73Abab & $3,18 \mathrm{Ab}$ & 16,9Вса & $1,99 \mathrm{Ab}$ & 4,97Aab & $3,83 \mathrm{Ab}$ & $3,65 \mathrm{Ab}$ & $6,95 B$ \\
\hline D & 25,74Aab & $13,52 \mathrm{Abc}$ & $5,83 \mathrm{Ac}$ & $6,08 \mathrm{Ac}$ & $15,11 \mathrm{Abc}$ & $3,85 \mathrm{Ac}$ & 39,51Aa & $12,68 \mathrm{Abc}$ & $9,67 \mathrm{Abc}$ & 8,32Abc & $8,57 \mathrm{Abc}$ & $13,53 A$ \\
\hline Média & $17,08 a b$ & $10,82 b c$ & $8,01 b c$ & $5,35 c$ & $11,56 b c$ & $4,65 c$ & $24,06 a$ & $7,11 c$ & $8,20 b c$ & $5,70 c$ & $5,41 c$ & \\
\hline
\end{tabular}

Médias seguidas por letras maiúsculas e minúsculas diferentes, respectivamente em colunas e linhas, diferem entre si a 5 \% de probabilidade pelo Teste de Tukey.
(E) tubetes de $290 \mathrm{~mL}$
(F) sacolas de 1,7L
(G) transplante de tubetes de $75 \mathrm{~mL}$ para sacolas de $1,7 \mathrm{~L}$
(H) transplante de tubetes de $75 \mathrm{~mL}$ para sacolas de $4,5 \mathrm{~L}$ 
Tabela 7. Matéria fresca de parte aérea (MFA) e matéria seca de parte aérea (MAS) de onze porta-enxertos, 240 dias após semeadura em quatro sistemas de produção. Piracicaba,

\begin{tabular}{|c|c|c|c|c|c|c|c|c|c|c|c|c|}
\hline & & & & & & rta-enxel & & & & & & \\
\hline $\begin{array}{c}\text { Sistema de } \\
\text { Produção }\end{array}$ & Cravo & Swingle & Cleópatra & Sunki & $\begin{array}{c}\text { Volka- } \\
\text { meriano }\end{array}$ & Caipira & Rugoso & Davis A & Barnes & $\begin{array}{l}\text { Sun Shu } \\
\text { Sha Kat }\end{array}$ & Sunki 2506 & Média \\
\hline MFA & & & & & & (g) & & & & & & \\
\hline A & $12,84 \mathrm{Ca}$ & $10,20 \mathrm{Ba}$ & $11,97 \mathrm{Ba}$ & $14,31 \mathrm{Ba}$ & $12,97 \mathrm{Ca}$ & 10,92Aa & $24,89 \mathrm{Da}$ & 4,81Ba & $10,91 \mathrm{Aa}$ & $9,61 \mathrm{Ba}$ & $12,02 \mathrm{Ba}$ & $12,31 D$ \\
\hline B & $87,29 \mathrm{Ab}$ & $48,15 \mathrm{Ac}$ & 37,31Ac & $38,57 \mathrm{Ac}$ & 99,75Aab & $28,57 \mathrm{Ac}$ & $122,37 \mathrm{Aa}$ & $25,61 \mathrm{Ac}$ & $28,87 \mathrm{Ac}$ & $29,70 \mathrm{Ac}$ & $37,94 \mathrm{Ac}$ & $53,10 A$ \\
\hline C & 38,31Bab & 25,07Bab & 17,29Abb & $20,29 \mathrm{Abb}$ & $41,45 \mathrm{Bab}$ & $18,48 \mathrm{Ab}$ & $51,57 \mathrm{Ca}$ & $18,25 \mathrm{Ab}$ & $16,81 \mathrm{Ab}$ & $16,15 \mathrm{Abb}$ & 20,19Abb & $25,80 C$ \\
\hline D & $54,88 \mathrm{Bb}$ & 30,04Abbc & $28,7 \mathrm{Abbc}$ & $27,2 \mathrm{Abbc}$ & $53,23 \mathrm{Bb}$ & $18,18 \mathrm{Ac}$ & $83,66 \mathrm{Ba}$ & $7,43 \mathrm{Bc}$ & $28,30 \mathrm{Abc}$ & $19,35 \mathrm{Abc}$ & 32,82Abc & $34,90 B$ \\
\hline Média & $48,33 b$ & $28,36 c$ & $23,8 c d$ & $25,11 c d$ & $51,85 b$ & $19,04 c d$ & $70,62^{a}$ & $14,02 d$ & $21,22 c d$ & $18,70 c d$ & $25,74 c d$ & \\
\hline MAS & & & & & & (g) & & & & & & \\
\hline $\mathbf{A}$ & 5,36Ca & 4,35Ba & $4,20 \mathrm{Aa}$ & 6,01Aa & $5,40 \mathrm{Ca}$ & 4,36Aa & $5,58 \mathrm{Da}$ & 1,96Aa & 4,25Ba & 3,60Aa & 4,55Aa & $4,51 D$ \\
\hline B & $35,94 \mathrm{Ab}$ & $20,66 \mathrm{Ac}$ & $13,15 \mathrm{Ac}$ & $13,97 \mathrm{Ac}$ & $38,02 \mathrm{Ab}$ & $10,17 \mathrm{Ac}$ & $63,47 \mathrm{Aa}$ & $11,65 \mathrm{Ac}$ & $17,16 \mathrm{Ac}$ & $10,64 \mathrm{Ac}$ & $13,34 \mathrm{Ac}$ & $22,56 A$ \\
\hline $\mathrm{C}$ & 16,33Bab & 7,93Bab & $5,95 \mathrm{Ab}$ & $7,60 \mathrm{Ab}$ & $15,80 \mathrm{Bab}$ & $6,14 \mathrm{Ab}$ & $20,55 \mathrm{Ca}$ & $5,40 \mathrm{Ab}$ & $5,98 \mathrm{Bb}$ & $5,66 \mathrm{Ab}$ & 7,58Ab & $9,54 C$ \\
\hline D & 22,39Bab & 11,16ABbc & $10,81 \mathrm{Abc}$ & $10,03 \mathrm{Abc}$ & 20,79Bab & 4,94Ac & $33,60 \mathrm{Ba}$ & 5,97Ac & $10,76 \mathrm{ABbc}$ & $6,55 \mathrm{Ac}$ & $12,52 \mathrm{Abc}$ & $13,59 B$ \\
\hline Média & $20,01 b$ & $11,02 c$ & $8,52 c$ & $9,40 c$ & $20,00 b$ & $6,40 c$ & $30,80 a$ & $6,25 c$ & $9,54 c$ & $6,61 c$ & $9,50 c$ & \\
\hline
\end{tabular}

Médias seguidas por letras maiúsculas e minúsculas diferentes, respectivamente em colunas e linhas, diferem entre si a 5 \% de probabilidade pelo Teste de Tukey
(A) tubetes de $290 \mathrm{~mL}$
(B) sacolas de $1,7 \mathrm{~L}$
(C) transplante de tubetes de $75 \mathrm{~mL}$ para sacolas de $1,7 \mathrm{~L}$
(D) transplante de tubetes de $75 \mathrm{~mL}$ para sacolas de $4,5 \mathrm{~L}$ 
Tabela 8. Concentração de clorofila nas folhas e volume de sistema radicular de onze porta-enxertos, 270 dias após semeadura em quatro sistemas de produção. Piracicaba, 2004

\begin{tabular}{|c|c|c|c|c|c|c|c|c|c|c|c|c|}
\hline \multicolumn{13}{|c|}{ Porta-enxerto } \\
\hline $\begin{array}{l}\text { Sistema de } \\
\text { Produção }\end{array}$ & Cravo & Swingle & $\begin{array}{c}\text { Sistema } \\
\text { de } \\
\text { Produção }\end{array}$ & Cravo & Swingle & $\begin{array}{l}\text { Sistema de } \\
\text { Produção }\end{array}$ & Cravo & Swingle & $\begin{array}{l}\text { Sistema de } \\
\text { Produção }\end{array}$ & Cravo & Swingle & Média \\
\hline \multicolumn{13}{|c|}{$\begin{array}{l}\text { Concentração de clorofila nas folhas } \\
\text { (spad) }\end{array}$} \\
\hline A & 55,20 & 69,85 & 62,05 & 50,83 & 53,35 & 76,50 & 53,40 & 84,60 & 74,38 & 61,95 & 57,68 & $62,04 B$ \\
\hline B & 64,03 & 66,55 & 61,95 & 63,60 & 57,25 & 70,33 & 60,28 & 80,38 & 75,05 & 64,83 & 65,95 & 66,38 A \\
\hline C & 61,10 & 64,20 & 57,90 & 53,55 & 55,00 & 70,70 & 59,48 & 70,50 & 75,05 & 60,68 & 64,38 & $63,62 A B$ \\
\hline $\mathbf{D}$ & 65,08 & 66,93 & 54,68 & 67,45 & 58,35 & 74,40 & 59,28 & 83,18 & 73,70 & 66,35 & 69,10 & 67,13 A \\
\hline Média & $61,35 \mathrm{def}$ & $66,88 b c d$ & 59,14 def & 58,85 ef & $55,98 f$ & $72,98 a b$ & 58,10 ef & $79,66 a$ & $72,04 a b c$ & $63,45 \mathrm{def}$ & 64,27 cde & \\
\hline \multicolumn{13}{|c|}{$\begin{array}{l}\text { Volume Sistema Radicular } \\
\text { (mL) }\end{array}$} \\
\hline A & $15,0 \mathrm{Ba}$ & $15,0 \mathrm{Ba}$ & $10,0 \mathrm{Ba}$ & $12,5 \mathrm{Ba}$ & $10,0 \mathrm{Ba}$ & 10,0 Аа & $15,0 \mathrm{Ca}$ & 7,50Aa & $13,5 \mathrm{Ba}$ & $10,0 \mathrm{Ba}$ & $10,0 \mathrm{Ba}$ & $11,81 C$ \\
\hline B & 70,0 Aab & $35,0 \mathrm{Bb}$ & $15,0 \mathrm{Bb}$ & $25,0 \mathrm{Bb}$ & 65,0 Aab & $30,0 \mathrm{Ab}$ & $85,0 \mathrm{Ba}$ & $25,0 \mathrm{Ab}$ & $35,0 \mathrm{ABb}$ & $35,0 \mathrm{Ab}$ & $30,0 \mathrm{Ab}$ & $38,86 B$ \\
\hline C & 70,0 Аа & $35,0 \mathrm{Bb}$ & $15,0 \mathrm{Bb}$ & $25,0 \mathrm{Bb}$ & 65,0 Aab & $30,0 \mathrm{Ab}$ & $85,0 \mathrm{Ba}$ & $25,0 \mathrm{Ab}$ & $35,0 \mathrm{ABb}$ & $35,0 \mathrm{Ab}$ & $30,0 \mathrm{Ab}$ & 38,86 B \\
\hline D & $85,0 \mathrm{Ab}$ & 60,0 Acd & 45,00 Ade & 45,0 Acd & 65,0 Abc & 30,0 Ae & $100,0 \mathrm{Aa}$ & $25,0 \mathrm{Ae}$ & 45,0 Acde & 40,0 Ade & 40,0 Acde & 54,32 A \\
\hline Média & $61,25 a b$ & $30,00 \mathrm{c}$ & $23,75 c$ & $31,25 \mathrm{C}$ & $51,56 b$ & $20,00 \mathrm{c}$ & $69,37 a$ & $20,31 \mathrm{c}$ & $29,53 c$ & $27,96 \mathrm{c}$ & $30,62 c$ & \\
\hline
\end{tabular}

Médias seguidas por letras maiúsculas e minúsculas diferentes, respectivamente em colunas e linhas, diferem entre si a 5\% de probabilidade pelo Teste de Tukey
(I) tubetes de $290 \mathrm{~mL}$
(J) sacolas de $1,7 \mathrm{~L}$
(K) transplante de tubetes de $75 \mathrm{~mL}$ para sacolas de $1,7 \mathrm{~L}$
(L) transplante de tubetes de $75 \mathrm{~mL}$ para sacolas de $4,5 \mathrm{~L}$ 


\subsubsection{Comparação dos custos de produção}

A determinação do custo de produção provável para as plantas geradas neste experimento foi baseada no estudo de Pozzan \& Kanashiro (2004), que considera a formação de muda cítrica em ciclo de produção de nove meses, em recipientes de 5,38L e com descarte de $5 \%$ do total de mudas produzidas. Como o desenvolvimento das espécies de porta-enxerto foi similar, em média, dentro de um mesmo sistema de produção de subenxerto, determinou-se que a avaliação de custo deveria se dar apenas ao nível de sistema de produção e não de espécie de porta-enxerto, a fim de evitar detalhamento desnecessário. O sistema de produção que implica transplante de portaenxertos de tubetes de 290mL para sacolas de 4,5L não foi avaliado, pois não constitui opção para subenxertia, mas sim parâmetro comparativo para a situação de posterior enxertia e formação de muda.

A análise dos custos de produção dos porta-enxertos indica que o sistema de produção em tubetes de 290mL é o mais barato (Tabela 9). Contudo, não leva em consideração o padrão inferior de desenvolvimento das plantas obtidas, e sua possível influência sobre o desenvolvimento pós-subenxertia a campo.

É interessante apontar que embora o vigor de crescimento dos porta-enxertos semeados diretamente em sacolas de 1,7L seja evidente, apontam-se algumas desvantagens, além do maior custo: a necessidade de aumentar o número de sementes por recipiente, no caso de espécies que apresentam altas taxas de embriões zigóticos e baixa poliembrionia, e o fato de plantas produzidas em tubetes de $75 \mathrm{~mL}$ permitirem maior versatilidade de uso e possibilidade de transplante mais fácil no caso de quebras de contrato ${ }^{4}$. Por outro lado, a rápida formação e grande tamanho das plantas são destacados como características desejáveis para um subenxerto.

Desta forma, a decisão sobre qual tipo de subenxerto adquirir dependerá não somente das condições do pomar a ser subenxertado, o que determinará o número e o tamanho dos subenxertos (Tersi, 2004), como também do acerto comercial do viveirista com o comprador.

\footnotetext{
${ }^{4}$ CORTE, R.D. Comunicação pessoal, 2005.
} 
Tabela 9. Custos de produção de porta-enxertos para fins de subenxertia em quatro sistemas de produção. Piracicaba, 2005

\begin{tabular}{|c|c|c|c|c|}
\hline $\begin{array}{l}\text { Custos } \\
\text { Muda Cítrica }^{1}\end{array}$ & $\begin{array}{c}\text { Sistema } \\
\text { Convencional }\end{array}$ & $A^{2}$ & $\mathbf{B}^{3}$ & $\mathrm{C}^{4}$ \\
\hline \multicolumn{5}{|l|}{ Operacionais } \\
\hline \multicolumn{5}{|l|}{ Insumos } \\
\hline \multicolumn{5}{|l|}{ borbulhas } \\
\hline Substrato & 0,36 & 0,02 & 0,13 & 0,13 \\
\hline Adubos / & 0,32 & $0,00 *$ & 0,11 & 0,11 \\
\hline \multicolumn{5}{|l|}{ Defensivos } \\
\hline Materiais & 0,12 & 0,02 & 0,04 & 0,06 \\
\hline Subtotal & 1,64 & 0,08 & 0,43 & 0,65 \\
\hline \multicolumn{5}{|l|}{ Mão-de-obra } \\
\hline enchimento & 0,39 & 0,03 & 0,14 & 0,29 \\
\hline \multicolumn{5}{|l|}{ e defensivos } \\
\hline \multicolumn{4}{|l|}{ e outras operações } & 0,10 \\
\hline Administração & 0,16 & 0,06 & 0,06 & 0,08 \\
\hline Subtotal & 0,93 & 0,12 & 0,33 & 0,53 \\
\hline Total & 2,57 & 0,20 & 0,75 & 1,18 \\
\hline \multicolumn{5}{|l|}{ Operacional } \\
\hline \multicolumn{3}{|l|}{$\underline{\text { Manutenção + }}$} & 0,27 & 0,27 \\
\hline \multicolumn{5}{|l|}{$\underline{\text { Certificados + Juros }}$} \\
\hline Total Custo & 3,35 & 0,22 & 1,03 & 1,45 \\
\hline
\end{tabular}

${ }^{1}$ Valores em R\$/muda.

${ }^{2} \mathrm{~A}$ - plantas obtidas em tubetes de $290 \mathrm{~mL}$

${ }^{3} \mathrm{~B}$ - plantas obtidas diretamente em sacolas de $1,7 \mathrm{~L}$

${ }^{4} \mathrm{C}$ - plantas obtidas de tubetes de $75 \mathrm{~mL}$ e transplantadas para sacolas de $1,7 \mathrm{~L}$

*valores menores que R\$ 0,001 foram considerados nulos 


\subsection{Produção de mudas de laranja 'Pêra' (Citrus sinensis L.Osbeck) sobre porta- enxertos limão 'Volkameriano' (Citrus volkameriana Pasquale) e citrumelo 'Swingle' (Poncirus trifoliata $x$ Citrus paradisi) através de interenxertia em ambiente protegido}

O citrumelo 'Swingle' sempre apresentou maior altura que limão 'Volkameriano', com respectivamente 117,4cm e 95,5cm no momento da interenxertia. Logo após o transplante dos porta-enxertos para sacolas plásticas, observaram-se sintomas de dieback do ponteiro e amarelecimento de folhas do terço superior no limão 'Volkameriano', provavelmente em decorrência de deficiência nutricional de cobre ou distúrbio fisiológico não definido. Isto deve ter prejudicado o desenvolvimento do limão 'Volkameriano', uma vez que se esperava maior vigor por parte deste porta-enxerto. Após a enxertia os sintomas desapareceram. Em todos os períodos avaliados, de 60 a 150 dias após a interenxertia, citrumelo 'Swingle’ induziu maior altura à copa que limão 'Volkameriano' (Tabela 10), sendo tangerina 'Sunki' a mais vigorosa, seguida de tangerina 'Cleópatra' e depois as três laranjas doces.

A sobrevivência de interenxertia foi superior para o citrumelo 'Swingle', com 90\% das borbulhas vivas 25 dias após a interenxertia, enquanto limão 'Volkameriano' apresentou 77,22\% de sobrevivência (Tabela 10). Laranja 'Pêra' enxertada em 'Volkameriano' determinou a pior sobrevivência de borbulhas, apenas 50\%. Contudo, durante todo o período de avaliação, não foram constatados sintomas de incompatibilidade entre copa e porta-enxerto nem influência do interenxerto no vigor da planta, sendo que tais manifestações podem ocorrer somente após o plantio no campo e ao longo da vida produtiva do pomar. A incompatibilidade dos citros é devida a um fator fisiológico e não infeccioso, caracterizando-se inicialmente por penetração da casca do lenho em parte ou em toda circunferência do tronco, quase sempre acompanhada de formação de goma tanto na casca como no lenho (Salibe, 1969). Tais sintomas, em geral, se manifestam um a dois anos após a enxertia, além de sintomas secundários como morte de radicelas e raízes, brotações anormais no porta-enxerto e amarelecimento de folhas. A planta tem crescimento reduzido ou morre após alguns anos. Nestes casos, a 
união entre tecidos do porta-enxerto e do enxerto é deficiente, com áreas sem união de tecidos ou com tecido necrosado, decorrente de rejeição entre tecidos e diferenças de calibre de vasos de floema e xilema (Valero, 1984). Há ainda autores que consideram também a possibilidade da incompatibilidade ser causada por agente de natureza virótica, uma vez que constataram transmissão de sintomas de incompatibilidade através de borbulhia, em trabalhos envolvendo laranja 'Pêra', limão 'Rugoso' e pomelos (Mc Lean, 1972).

Embora o ciclo de produção da muda interenxertada seja elevado, cerca de 17 meses após a semeadura dos porta-enxertos, e isto seja uma desvantagem para o viveirista, a possibilidade de manipulação do tamanho das plantas via interenxertia e conseqüente adensamento de pomares torna esta técnica promissora para esta finalidade (Castle, 1981; Krezdorn, 1978), além de permitir maior diversificação do uso de portaenxertos para a laranja 'Pêra' no Brasil. Neste caso, a possibilidade de emprego do citrumelo 'Swingle’ como porta-enxerto para laranja 'Pêra' é fundamental nas áreas já afetadas pela MSC.

Ao contrário do observado em relação aos interenxertos antes da enxertia, o comprimento do enxertos de laranja 'Pêra' não foi influenciado pelo interenxerto ou porta-enxerto, a não ser por maior comprimento de enxerto de laranja 'Pêra' em interenxerto de laranja 'Pêra' sobre limão 'Volkameriano', em relação às mesmas mudas sobre citrumelo 'Swingle’ (Tabela 11). Embora laranja 'Pêra' seja incompatível com limão 'Volkameriano', não se observaram sintomas típicos de incompatibilidade até o final do ensaio, sendo que, na verdade, o vigor destas mudas foi considerável. Diferenças de tamanho de plantas poderiam ser observadas somente após a implantação do pomar, ao longo de sua vida produtiva (Carlos, 1996). Há pomares produtivos e relativamente longevos desta combinação em São Paulo e são bastante comuns em outras regiões, como em Sergipe, o que demonstra que a produção comercial poderia ser sustentável mesmo com a incompatibilidade desta combinação.

O interenxerto de tangerina 'Sunki' induziu a maior percentagem de borbulhas dormentes (36,78\%) quando comparado com os de laranjas 'Valência' e 'Pêra', respectivamente 22,93\% e 22,68\% (Tabela 11). Desta forma, não houve influência do 
porta-enxerto mas apenas do interenxerto, se comportando como um novo "portaenxerto" para a copa de laranja 'Pêra'. Nos viveiros comerciais é bastante comum se verificar a menor percentagem de pegamento de enxertia de laranjas doces sobre tangerina 'Sunki', o que leva muitos viveiristas a tomar ações como aplicação de fitorreguladores sobre borbulhas recém enxertadas ou aumentar o número de plantas em lotes enxertados sobre 'Sunki' para compensar as perdas ${ }^{5}$. Não houve diferença entre os tratamentos quanto à percentagem de borbulhas mortas, sendo indicativo que esta variável não seja influenciada pelo porta-enxerto ou combinação copa/porta-enxerto, mas sim por fatores intrínsecos à borbulha ou até mesmo por falha no ato mecânico da enxertia. Neste experimento, a taxa média de morte de borbulhas foi de 6,7\%. Também não se constataram diferenças entre os tratamentos quanto a diâmetro final do portaenxerto, interenxerto e enxerto (Tabela 12).

Citrumelo 'Swingle’ superou limão 'Volkameriano' tanto em matéria fresca e seca de parte aérea como de sistema radicular (Tabela 13). No caso da parte aérea, foi medido o caule do porta-enxerto somado ao enxerto inteiro. Como citrumelo 'Swingle' alcançou diâmetro superior, era esperado que sua massa também superasse à do 'Volkameriano', o que explica em parte a matéria de parte aérea ser maior. Quanto ao volume do sistema radicular, não houve diferença entre os tratamentos, atingindo-se volume médio de $65 \mathrm{~mL}$ para ambos os porta-enxertos (dados não apresentados). Este é um fato interessante, pois citrumelo 'Swingle' acumulou maior massa seca de sistema radicular, o que é um indicativo de diferenças entre os porta-enxertos quanto à densidade ou ainda conformação do sistema radicular. O limão 'Volkameriano', assim como o limão 'Cravo', apresenta um sistema radicular bastante ramificado, mas de estrutura mais pilosa, enquanto os citrumelos se caracterizam pelo sistema radicular mais proeminente, conforme relatado por Wutscher (1998). Castle \& Youtsey (1977), em estudo em que descrevem o sistema radicular de mudas de laranja 'Valência' enxertada sobre 12 porta-enxertos e produzidas em viveiro aberto, classificaram o sistema radicular de limão 'Volkameriano’ como vigoroso e profundo, superando o sistema radicular de outras espécies vigorosas como limão ‘Rugoso’. Por outro lado, o citrumelo

\footnotetext{
${ }^{5}$ TOZATTI, G. Comunicação pessoal, 2005.
} 
'Swingle', embora apresentasse sistema radicular menor e pouco ramificado, caracterizou-se por raízes mais grossas que todos os demais porta-enxertos, de forma a apresentar um sistema radicular típico e distinto do padrão de sistema radicular de citros.

\subsubsection{Comparação dos custos de produção}

Para a comparação dos custos de produção neste experimento utilizou-se a mesma metodologia descrita para o ensaio anterior. O elevado índice de descarte verificado neste ensaio, em média 35\%, além da operação redobrada de enxertia, faz com que este tipo de muda tenha custo bem superior ao observado para muda convencional (Tabela 14). Além disso, caracteriza-se por um ciclo de produção mais prolongado e minucioso, levando-se até 17 meses para a formação da muda a partir da semeadura do portaenxerto. Em alguns tratamentos o descarte chegou a 60 \%, sendo resultado do somatório de perdas ocorridas nas duas enxertias realizadas no processo.

Mesmo assim, a interenxertia se mostrou uma técnica promissora para propagação de citros, especialmente no caso de combinações copa/porta-enxerto incompatíveis. Somente informações a respeito do sucesso de pomares futuros poderiam determinar se a relação custo-benefício justificaria o uso de mudas interenxertadas. Deve-se ponderar que este tipo de muda seria plantada em regiões de características especiais, tais quais as áreas seriamente afetadas pela MSC ou cujo destino da produção seja, preferencialmente, a industrialização, portanto com condições que permitiriam um maior custo de implantação do pomar em prol de ganhos de sanidade e longevidade da produção. 
Tabela 10. Sobrevivência de enxertia e comprimento do interenxerto de laranjas 'Pêra', 'Valência' e 'Hamlin’ e tangerinas ‘Sunki’ e ‘Cleópatra’ enxertadas sobre citrumelo ‘Swingle’ e limão ‘Volkameriano’ 60, 90, 120 e 150 dias após a enxertia. Piracicaba, 2004

\begin{tabular}{cc}
\hline & \multicolumn{3}{c}{ Interenxerto } \\
Porta-enxerto & 'Pêra' 'Valência' 'Hamlin' 'Sunki' 'Cleópatra' Média \\
\hline
\end{tabular}

\section{Sobrevivência de interenxertia}

\begin{tabular}{ccccccc} 
& & \multicolumn{5}{c}{$\mathbf{( \% )}$} \\
'Swingle' & $86,11 \mathrm{Aa}$ & $80,56 \mathrm{Aa}$ & $88,89 \mathrm{Aa}$ & $97,22 \mathrm{Aa}$ & $97,22 \mathrm{Aa}$ & $90,00 \mathrm{~A}$ \\
'Volkameriano' & $50,00 \mathrm{Bb}$ & $72,22 \mathrm{Aab}$ & $83,33 \mathrm{Aa}$ & $91,67 \mathrm{Aa}$ & $88,89 \mathrm{Aa}$ & $77,22 \mathrm{~B}$ \\
Média & $68,06 \mathrm{~b}$ & $76,39 \mathrm{ab}$ & $86,11 \mathrm{ab}$ & $94,45 \mathrm{a}$ & $93,06 \mathrm{ab}$ &
\end{tabular}

\section{Comprimento do interenxerto}

\begin{tabular}{|c|c|c|c|c|c|c|}
\hline & & & (cm) & & & \\
\hline $60 \mathrm{DAE}$ & & & & & & \\
\hline 'Swingle' & 21,02Ad & 22,56Acd & $28,41 \mathrm{Ac}$ & 43,84Aa & $36,81 \mathrm{Ab}$ & $30,53 A$ \\
\hline 'Volkameriano' & $17,47 \mathrm{Ac}$ & $26,60 \mathrm{Ab}$ & $22,71 \mathrm{Abc}$ & $37,41 \mathrm{Ba}$ & $26,49 \mathrm{Bb}$ & $26,14 B$ \\
\hline Média & $19,24 c$ & $24,58 b c$ & $25,56 b c$ & $40,62 a$ & $31,65 b$ & \\
\hline $90 \mathrm{DAE}$ & & & & & & \\
\hline 'Swingle' & 32,94Ac & $37,10 \mathrm{Ac}$ & 43,11Ac & 80,33Аа & $62,02 \mathrm{Ab}$ & $51,10 A$ \\
\hline 'Volkameriano' & 24,99Bc & $31,79 B \mathrm{~B}$ & 33,39Bc & $58,68 \mathrm{Ba}$ & $44,24 \mathrm{Bb}$ & $38,62 B$ \\
\hline Média & $28,96 c$ & $34,44 c$ & $38,25 c$ & $69,50 a$ & $53,13 b$ & \\
\hline $120 \mathrm{DAE}$ & & & & & & \\
\hline 'Swingle' & 30,78Ac & $36,14 \mathrm{Ac}$ & 43,05Ac & $107,23 \mathrm{Aa}$ & 77,91Ab & $59,02 A$ \\
\hline 'Volkameriano' & $20,87 \mathrm{Bc}$ & $29,88 \mathrm{Bc}$ & 34,39Bс & $75,93 \mathrm{Ba}$ & $56,96 \mathrm{Bb}$ & $43,61 B$ \\
\hline Média & $25,82 c$ & $33,01 c$ & $38,72 c$ & $91,58 a$ & $67,43 b$ & \\
\hline $150 \mathrm{DAE}$ & & & & & & \\
\hline 'Swingle' & 39,43Ac & 44,97Ac & 43,27Ac & $122,56 \mathrm{Aa}$ & $87,88 \mathrm{Ab}$ & $67,62 A$ \\
\hline 'Volkameriano' & 33,57Ac & $32,92 \mathrm{Bc}$ & 40,83Ac & $91,77 \mathrm{Ba}$ & $74,06 \mathrm{Bb}$ & $54,63 B$ \\
\hline Média & $36,5 c$ & $38,94 C$ & $42,05 c$ & $107,16 a$ & $80,97 b$ & \\
\hline
\end{tabular}

Médias seguidas por letras maiúsculas e minúsculas diferentes, respectivamente em colunas e linhas, diferem entre si a $5 \%$ de probabilidade pelo Teste de Tukey. 
Tabela 11. Percentagem de borbulhas dormentes e comprimento de enxerto de laranja 'Pêra' enxertada sobre interenxertos de laranjas 'Pêra', 'Valência' e 'Hamlin' e tangerinas 'Sunki’ e ‘Cleópatra', sobre porta-enxertos citrumelo 'Swingle’ e limão ‘Volkameriano’, 100 dias após a enxertia. Piracicaba, 2004

\section{Interenxerto}

Média

Porta-enxerto 'Pêra' 'Valência' 'Hamlin' 'Sunki' 'Cleópatra'

\section{Borbulhas dormentes de laranja 'Pêra'}

(\%)

$\begin{array}{ccccccc}\text { 'Swingle' } & 13,89 & 25,00 & 27,78 & 30,56 & 25,00 & 29,26 \mathrm{~A} \\ \text { 'Volkameriano' } & 16,67 & 11,11 & 13,89 & 41,67 & 16,67 & 25,00 \mathrm{~A} \\ \text { Média } & 22,68 b & 22,93 b & 26,58 a b & 36,78 a & 26,74 a b & \end{array}$

Comprimento do enxerto de laranja 'Pêra'

(cm)

$\begin{array}{lllllll}\text { 'Swingle' } & 55,50 \mathrm{~B} & 71,78 \mathrm{~A} & 61,20 \mathrm{~A} & 57,33 \mathrm{~A} & 65,08 \mathrm{~A} & 62,17 \mathrm{~A}\end{array}$ $\begin{array}{llllll}\text { 'Volkameriano' } & 77,14 \mathrm{~A} & 61,91 \mathrm{~A} & 70,38 \mathrm{~A} & 59,83 \mathrm{~A} & 64,02\end{array}$ $\begin{array}{llllll}\text { Média } & 66,32 a & 66,84 a & 65,78 a & 58,58 a & 64,55 a\end{array}$

Médias seguidas por letras maiúsculas e minúsculas diferentes, respectivamente em colunas e linhas, diferem entre si a $5 \%$ de probabilidade pelo Teste de Tukey. 
Tabela 12. Diâmetros de enxerto, interenxerto e porta-enxerto de mudas de laranja 'Pêra' enxertada sobre interenxertos de laranjas 'Pêra', 'Valência' e 'Hamlin' e tangerinas 'Sunki' e ‘Cleópatra', sobre os porta-enxertos citrumelo 'Swingle’ e limão 'Volkameriano', 100 dias após a enxertia. Piracicaba, 2004

\begin{tabular}{|c|c|c|c|c|c|c|}
\hline \multirow[b]{2}{*}{ Porta-enxerto } & \multicolumn{5}{|c|}{ Interenxerto } & \multirow[b]{2}{*}{ Média } \\
\hline & 'Pêra' & 'Valência' & 'Hamlin' & ‘Sunki’ & 'Cleópatra' & \\
\hline \multicolumn{7}{|c|}{ Diâmetro de enxerto de laranja 'Pêra' } \\
\hline 'Swingle' & 7,06 & 6,76 & 7,32 & 6,96 & 7,46 & $7,11 A$ \\
\hline 'Volkameriano' & 6,96 & 7,51 & 7,53 & 7,23 & 7,71 & 7,38 A \\
\hline Média & $7,01 a$ & $7,13 a$ & $7,42 a$ & $7,09 a$ & $7,58 a$ & \\
\hline \multicolumn{7}{|c|}{ Diâmetro dos interenxertos } \\
\hline 'Swingle' & 8,83 & 9,50 & 8,56 & 8,96 & 9,18 & $9,00 \mathrm{~A}$ \\
\hline 'Volkameriano' & 8,94 & 10,33 & 10,19 & 8,68 & 9,42 & $9,50 \mathrm{~A}$ \\
\hline Média & $8,88 a$ & $9,91 a$ & $9,37 a$ & $8,82 a$ & $9,30 a$ & \\
\hline
\end{tabular}

\section{Diâmetro dos porta-enxertos}

(mm)

\begin{tabular}{ccccccc} 
'Swingle' & 15,08 & 16,17 & 14,63 & 12,71 & 14,57 & $14,63 \mathrm{~A}$ \\
'Volkameriano' & 10,91 & 12,63 & 13,31 & 12,05 & 13,19 & $12,42 \mathrm{~B}$ \\
Média & $12,99 a$ & $14,39 a$ & $13,97 a$ & $12,38 a$ & $13,87 a$ & \\
\hline
\end{tabular}

Médias seguidas por letras maiúsculas e minúsculas diferentes, respectivamente em colunas e linhas, diferem entre si a $5 \%$ de probabilidade pelo Teste de Tukey. 
Tabela 13. Matérias fresca e seca de parte aérea e sistema radicular de mudas de laranja 'Pêra’ enxertada sobre interenxertos de laranjas 'Pêra', ‘Valência’ e ‘Hamlin’ e tangerinas ‘Sunki’ e ‘Cleópatra', sobre os porta-enxertos citrumelo 'Swingle’ e limão 'Volkameriano’, 100 dias após a enxertia. Piracicaba, 2004

\begin{tabular}{llll}
\hline & \multicolumn{3}{c}{ Interenxerto } \\
Porta-enxerto & 'Pêra' 'Valência' 'Hamlin' 'Sunki' 'Cleópatra' Média \\
\hline
\end{tabular}

Matéria fresca parte aérea

(g)

$\begin{array}{ccccccc}\text { 'Swingle' } & 127,72 & 124,99 & 152,59 & 147,68 & 148,66 & 140,32 \mathrm{~A} \\ \text { 'Volkameriano' } & 99,59 & 122,10 & 114,69 & 103,51 & 101,30 & 108,24 \mathrm{~B} \\ \text { Média } & 113,65 a & 123,54 a & 133,63 a & 125,60 a & 124,98 a & \end{array}$

Matéria fresca sistema radicular

(g)

$\begin{array}{ccccccc}\text { 'Swingle' } & 92,14 & 71,56 & 90,80 & 80,72 & 91,85 & 85,41 \mathrm{~A} \\ \text { 'Volkameriano' } & 56,39 & 70,52 & 74,89 & 55,64 & 53,15 & 62,12 \mathrm{~B} \\ \text { Média } & 74,26 a & 71,04 a & 82,84 a & 68,18 a & 72,49 a & \end{array}$

Matéria seca parte aérea

(g)

$\begin{array}{ccccccc}\text { 'Swingle’ } & 49,69 & 47,3 & 57,85 & 56,16 & 57,5 & 53,70 \text { A } \\ \text { 'Volkameriano' } & 37,70 & 47,15 & 46,18 & 42,00 & 38,61 & 42,32 \text { B } \\ \text { Média } & 43,70 a & 47,22 a & 52,02 a & 49,07 a & 48,05 a & \end{array}$

Matéria seca sistema radicular

(g)

\begin{tabular}{ccccccc} 
'Swingle' & 35,76 & 29,73 & 38,36 & 31,35 & 37,42 & 34,52 A \\
'Volkameriano' & 22,01 & 29,93 & 31,55 & 23,64 & 21,59 & 25,75 B \\
Média & $28,88 a$ & $29,82 a$ & $34,95 a$ & $27,50 a$ & $29,50 a$ & \\
\hline Médias & seguidas & por letras maiúsculas & e minúsculas & diferentes, respectivamente & em colunas e linhas, \\
diferem entre si a $5 \%$ de probabilidade pelo Teste de Tukey.
\end{tabular}


Tabela 14. Custos de produção de muda de laranja 'Pêra' interenxertada em diferentes variedades. Piracicaba, 2005

\begin{tabular}{|c|c|c|}
\hline \multicolumn{3}{|l|}{ Muda Cítrica ${ }^{1}$} \\
\hline \multicolumn{3}{|l|}{ Operacionais } \\
\hline \multicolumn{3}{|l|}{ Insumos } \\
\hline \multicolumn{3}{|l|}{ borbulhas } \\
\hline Substrato & 0,36 & 0,30 \\
\hline Adubos / Defensivos & 0,32 & 0,39 \\
\hline Materiais & 0,12 & 0,14 \\
\hline Subtotal & 1,64 & 2,34 \\
\hline \multicolumn{3}{|l|}{ Mão-de-obra } \\
\hline enchimento & 0,39 & 0,33 \\
\hline Manejo de adubos e defensivos & 0,17 & 0,21 \\
\hline Desbrota, Seleção, Operações & 0,21 & 0,30 \\
\hline Administração & 0,16 & 0,19 \\
\hline Subtotal & 0,93 & 1,03 \\
\hline Total Operacional & 2,57 & 3,37 \\
\hline Depreciação + Manutenção + & 0,78 & 0,94 \\
\hline \multicolumn{3}{|l|}{$\underline{\text { Certificação + Juros }}$} \\
\hline Total Custo & 3,35 & $5,30 *$ \\
\hline
\end{tabular}

${ }^{1}$ Valores em R\$/muda.

*Considerando-se descarte médio de 35\% 


\subsection{Produção de estacas de citrumelo 'Swingle' (Poncirus trifoliata $x$ Citrus paradisi) para fins de enxertia no viveiro e subenxertia no campo}

Apenas estacas herbáceas atingiram 100\% de sobrevivência 90 dias após a estaquia, seguidas pelas estacas lenhosas com 99,37\% de sobrevivência (Tabela 15). Estacas semi-lenhosas previamente enxertadas apresentaram o menor índice de sobrevivência, inferior a 35\%. Trinta dias após colocar as estacas para enraizar em câmara de nebulização, foi realizada uma desbrota nas estacas lenhosas e semi-lenhosas, então com intensa brotação. Nas estacas que não haviam sido enxertadas antes da estaquia deixou-se apenas um broto, visando priorizar seu crescimento. Já nas estacas previamente enxertadas, todos os brotos foram retirados, pois se julgou que esta prática favoreceria o crescimento do enxerto, fato que não foi observado 60 dias depois (Tabelas 15 e 16). As estacas lenhosas enxertadas chegaram a rebrotar, embora com menor intensidade, o que era esperado, pois a lignificação está associada a maior acúmulo de reservas no tecido vegetal (Hartmann et al., 2002). Já as estacas semilenhosas enxertadas parecem ter sido muito afetadas pela desbrota, de modo que a taxa de sobrevivência caiu sensivelmente e todas as demais variáveis avaliadas foram prejudicadas, de modo que sequer foram transplantas para sacolas de 4,5L, como ocorreu com os demais tratamentos. Esta desbrota indevida pode ter influenciado nas variáveis avaliadas, inclusive influenciando no crescimento do enxerto; por exemplo, se não se realizasse a desbrota severa, talvez o crescimento do enxerto tivesse sido maior. Este fato condiz com autores que indicam que a presença de brotação e manutenção de folhas em estacas favorece o enraizamento e o sucesso da estaquia, devido à assimilação de fotoassimilatos, hormônios e/ou metabólitos secundários produzidos pelas folhas (Hartmann et al., 2002; Platt \& Opitz, 1973). Estacas herbáceas apresentaram o menor brotamento (5\%) 90 dias após a estaquia, embora tenham iniciado crescimento vigoroso logo após o transplante para sacolas.

Estacas herbáceas atingiram 100\% de enraizamento 90 dias após a estaquia, seguidas pelas estacas lenhosas com 91,25\% de enraizamento (Tabela 15). A imersão

em solução com IBA 500mg L $\mathrm{m}^{-1}$ por 10 segundos não intensificou o enraizamento das 
estacas. Estacas semi-lenhosas apresentaram o menor índice de enraizamento, 54,37\%, conforme discutido anteriormente. A presença de enxerto também não influenciou o enraizamento.

Noventa dias após a estaquia, a sobrevivência da enxertia foi cerca de 52\% superior em estacas lenhosas do que em semi-lenhosas (Tabela 16). Nos viveiros comerciais sempre se aguarda o início da lignificação do porta-enxerto para se proceder à borbulhia (Teófilo Sobrinho, 1991). A imersão em solução com IBA 500mg L $\mathrm{m}^{-1}$ por 10 segundos não influenciou a sobrevivência da enxertia. Por outro lado, os enxertos permaneceram dormentes durante todo o período de enraizamento.

Optou-se por realizar estaquia logo após a retirada dos fitilhos, 15 dias após a enxertia, pois, se fosse permitido o desenvolvimento inicial das borbulhas, estas, provavelmente, não suportariam o estresse sofrido e, mesmo em câmara de nebulização, estariam muito sujeitas à desidratação. Aumentar a chance de sobrevivência das borbulhas, mesmo que sem crescimento inicial, passa a ser prioritário, pois, o forçamento da enxertia pode ser realizado após o enraizamento das estacas, evento inicialmente mais importante ${ }^{6}$. Mesmo assim, um novo ensaio, comparando enraizamento de estacas com diferentes graus de desenvolvimento de enxertos, é sugerido a fim de elucidar esta questão.

Estacas herbáceas apresentaram em média 4,14 raízes 90 dias após a estaquia, seguidas pelas estacas lenhosas, com 3,45 raízes (Tabela 16). Estacas semi-lenhosas apresentaram o menor número de raízes $(2,12)$. Estacas herbáceas também apresentaram maior raiz, com 7,40cm de comprimento médio 90 dias após a estaquia, seguidas pelas estacas lenhosas, com 4,10cm, e estacas semi-lenhosas, com 3,10cm (Tabela 16). A imersão em solução com IBA $500 \mathrm{mg} \mathrm{L}^{-1}$ por 10 segundos não favoreceu o comprimento da maior raiz.

Cerca de 30 dias após transplante (DAT), porta-enxertos de 'Swingle' provenientes de estacas herbáceas apresentavam maior altura que as demais (Tabela 17). Por outro lado, as plantas provenientes de sementes estavam bem mais desenvolvidas

\footnotetext{
${ }^{6}$ SCARPARE FILHO, J.A. Comunicação pessoal, 2004.
} 
que as obtidas de estacas. O crescimento inicial foi, portanto, proporcional ao sistema radicular existente.

As plantas obtidas de sementes tinham como vantagem inicial a presença de um sistema radicular já existente. Já 210 DAT, plantas obtidas de estacas não enxertadas superaram em alturas as obtidas de estacas lenhosas enxertadas e de sementes enxertadas (Tabela 17). A enxertia determinou, no caso dos seedlings, a interrupção no crescimento do porta-enxerto, além de uma atraso de brotação do enxerto em relação aos porta-enxertos provenientes de estacas, que não tiveram o crescimento interrompido. Já no caso das estacas enxertadas, o menor crescimento de parte aérea pode ser explicado tanto pelo fato do enxerto ter pequena área folhar, e assim houve menor produção e envio de fotoassimilatos para promover o desenvolvimento adequado do sistema radicular e conseqüente maior crescimento total, como por interações hormonais que não se manifestam no em plantas provenientes de pé-franco e que são decorrência da combinação entre enxerto e porta-enxerto, conforme descrito por Bertling \& Lovatt (1996). Estudando limão 'Rugoso' e Poncirus trifoliata, os autores determinaram que a detecção de ABA e IAA, respectivamente em alta e baixa concentrações em brotos e raízes novos, deve ser indício de características ananicantes do porta-enxerto, sendo a situação inversa provável indício de alto vigor vegetativo do porta-enxerto.

Sete meses após a enxertia, os porta-enxertos não estavam aptos para enxertia adequada conforme as normas de produção de mudas cítricas para o Estado de São Paulo (Panzani et al., 1994). Poder-se-ia aguardar mais alguns meses para se proceder à enxertia normalmente, mas o longo período transcorrido entre a estaquia e a enxertia torna mais viável para esta finalidade comercialmente o emprego de porta-enxertos obtidos a partir de sementes. Em contra-partida, os porta-enxertos apresentavam excelentes condições para subenxertia a campo, o que poderia ser uma finalidade mais apropriada para este tipo de propagação de citrumelo 'Swingle', apontado como portaenxerto próprio para subenxertia (Shaked et al., 1987). Reduzir o custo e facilitar a operacionalidade da subenxertia a campo é importante para implementar a prevenção da MSC nos pomares (Tersi, 2004). 
Sete meses após o transplante, plantas obtidas de estacas, independente de seu tipo, induziram maior diâmetro de caule que as obtidas de estacas lenhosas enxertadas e de seedlings enxertados (Tabela 17). A sobrevivência de enxertia foi similar entre plantas provenientes de sementes e de estacas lenhosas submetidas a solução com IBA 500 $\mathrm{mg} \mathrm{L}^{-1}$ (cerca de 92,0\%), superando expressivamente a sobrevivência em estacas provenientes de estacas lenhosas sem tratamento com fitorregulador (66,7\%) (Tabela 17). Este fato não era esperado uma vez que o tratamento com IBA não havia influenciado quaisquer variáveis durante o enraizamento das estacas na câmara de nebulização.

Porta-enxertos obtidos de estacas herbáceas e lenhosas apresentaram maior matéria seca de parte aérea e de sistema radicular, sete meses após o transplante das estacas (Tabela 18). Estacas submetidas a IBA 500 $\mathrm{mg} \mathrm{L}^{-1}$ acumularam maior teor de matéria seca de sistema radicular. Estacas semi-lenhosas apresentaram menor matéria seca mas ainda assim superior à observada para estacas lenhosas submetidas à enxertia antes do enraizamento. As mesmas considerações dadas à matéria seca se aplicam a volume do sistema radicular (Tabela 18). Tais resultados poderiam ser explicados pela área folhar das plantas. Embora não se tenha medido a área folhar de copa, plantas enxertadas devem ter apresentado menor área folhar uma vez que atingiram menor comprimento de brotação. Existe uma correlação positiva entre área folhar e variáveis como enraizamento de estacas, pegamento de enxertia e crescimento tanto de portaenxertos como enxertos (Williamson \& Maust, 1993). Bowman (1999) determinou que o método mais adequado para forçamento da enxertia em variedades de citros enxertadas sobre 19 variedades de citrumelos, inclusive 'Swingle', foi o de encurvamento da copa do porta-enxerto, provavelmente por manter uma área folhar maior em relação à decepa do porta-enxerto. Trabalhos envolvendo ${ }^{14} \mathrm{C}$ marcado demonstram que a maioria dos fotoassimilatos gerados em folhas de porta-enxertos encurvados são primariamente direcionados ao enxerto durante os fluxos de crescimento de mudas cítricas, e direcionados ao sistema radicular das mudas nos intervalos entre fluxos de crescimento do enxerto, evidenciando que em espécies cítricas as folhas do porta-enxerto são a fonte 
principal de fotoassimilatos para crescimento inicial do enxerto (Williamson et al., 1992).

Durante o enraizamento, observou-se que estacas herbáceas, seguidas das estacas lenhosas sem enxerto, atingiram melhor performance. Contudo, há de se considerar a desbrota feita nas estacas enxertadas, possivelmente com influência negativa sobre o crescimento das plantas obtidas nestes tratamentos. Outro fator foi a desbrota em estacas sem enxerto, a efeito de igualar tratos culturais com as estacas enxertadas, mas que também pode ter influenciando as variáveis avaliadas.

\subsubsection{Comparação dos custos de produção}

Para a comparação dos custos de produção neste experimento utilizou-se a mesma metodologia descrita para o ensaio anterior. A muda formada a partir de estacas enxertadas tem maior custo, pois leva mais tempo para ser formada, além de maior descarte (Tabela 19). Por outro lado, como se obtêm de duas a três estacas por portaenxerto, o custo de porta-enxerto é inferior. Já o subenxerto apresentou elevado custo, pois, se empregou uma sacola de 4,5L. Se as estacas fossem transplantadas para recipientes menores, como os tubetes de $290 \mathrm{~mL}$ ou sacolas de $1,7 \mathrm{~L}$, o custo seria compatível para a finalidade de subenxertia. Desta forma, a multiplicação de citrumelo 'Swingle' a partir de estacas herbáceas com um par de folhas é recomendável para a produção comercial de subenxertos deste híbrido. 
Tabela 15. Percentagem de sobrevivência, brotamento e enraizamento de estacas herbáceas, semi-lenhosas e lenhosas de citrumelo 'Swingle’, submetidas a enxertia e imersão em solução com IBA 0 e 500mg L ${ }^{-1}$, 90 dias após estaquia em câmara de nebulização. Piracicaba, 2004

\begin{tabular}{|c|c|c|c|c|c|}
\hline $\begin{array}{c}\text { IBA } \\
\left(\mathrm{mg} \mathrm{L}^{-1}\right)\end{array}$ & Enxerto & herbácea & $\begin{array}{l}\text { Tipo de estaca } \\
\text { Semi-lenhosa }\end{array}$ & lenhosa & Média \\
\hline & \multicolumn{5}{|c|}{ Sobrevivência } \\
\hline & \multicolumn{5}{|c|}{$(\%)$} \\
\hline $\mathbf{0}$ & ausente & $100,00 \mathrm{Aa}$ & 100,00Aa & $100,00 \mathrm{Aa}$ & $100,00 \mathrm{~A}$ \\
\hline $\mathbf{0}$ & presente & - & $20,00 \mathrm{Bb}$ & $100,00 \mathrm{Aa}$ & $60,00 B$ \\
\hline 500 & ausente & $100,00 \mathrm{Aa}$ & $97,50 \mathrm{Aa}$ & 97,50Aa & $98,33 A$ \\
\hline 500 & presente & - & $35,00 \mathrm{Bb}$ & 100,00Aa & $67,50 B$ \\
\hline \multirow[t]{2}{*}{ Média } & & $100,00 a$ & $63,12 b$ & $99,37 a$ & \\
\hline & \multicolumn{5}{|c|}{$\begin{array}{c}\text { Brotamento } \\
(\%)\end{array}$} \\
\hline $\mathbf{0}$ & ausente & $5,00 \mathrm{Ac}$ & $87,50 \mathrm{Ab}$ & 100,00Aa & $64,17 A$ \\
\hline $\mathbf{0}$ & presente & - & $7,50 \mathrm{Bb}$ & 92,50Aa & $50,00 B$ \\
\hline 500 & ausente & $5,00 \mathrm{Ac}$ & $87,50 \mathrm{Ab}$ & 97,50Aа & $63,33 A$ \\
\hline 500 & presente & - & $20,00 \mathrm{Bb}$ & 95,00Aa & $57,50 B$ \\
\hline \multirow[t]{2}{*}{ Média } & & $5,00 c$ & $50,62 b$ & $96,25 a$ & \\
\hline & \multicolumn{5}{|c|}{$\begin{array}{c}\text { Enraizamento } \\
(\%)\end{array}$} \\
\hline $\mathbf{0}$ & ausente & $100,00 \mathrm{Aa}$ & $90,00 A a$ & $100,00 \mathrm{Aa}$ & $96,67 A$ \\
\hline $\mathbf{0}$ & presente & - & $12,50 \mathrm{Bb}$ & 82,50Aa & $47,50 B$ \\
\hline 500 & ausente & $100,00 \mathrm{Aa}$ & $90,00 \mathrm{Aa}$ & $95,00 \mathrm{Aa}$ & $95,00 A$ \\
\hline 500 & presente & - & $25,00 \mathrm{Bb}$ & 87,50Aa & $56,25 B$ \\
\hline Média & & $100,00 a$ & $54,37 b$ & $91,25 a$ & \\
\hline
\end{tabular}

Médias seguidas por letras maiúsculas e minúsculas diferentes, respectivamente em colunas e linhas, diferem entre si a 5\% de probabilidade pelo Teste de Tukey 
Tabela 16. Sobrevivência de enxertia, número de raízes principais e comprimento de maior raiz de estacas herbáceas, semi-lenhosas e lenhosas de citrumelo 'Swingle', submetidas a enxertia e imersão em solução com IBA 0 e 500mg L ${ }^{-1}$, 90 dias após estaquia em câmara de nebulização. Piracicaba, 2004

\begin{tabular}{|c|c|c|c|c|c|}
\hline \multirow{2}{*}{$\begin{array}{c}\text { IBA } \\
\left(\mathrm{mg} \mathrm{L}^{-1}\right)\end{array}$} & \multirow[t]{2}{*}{ Enxerto } & \multicolumn{3}{|c|}{ Tipo de estaca } & \multirow[b]{2}{*}{ Média } \\
\hline & & herbácea & Semi-lenhosa & lenhosa & \\
\hline & \multicolumn{5}{|c|}{$\begin{array}{c}\text { Sobrevivência da enxertia } \\
(\%)\end{array}$} \\
\hline $\mathbf{0}$ & ausente & - & - & - & - \\
\hline $\mathbf{0}$ & presente & - & $20,00 \mathrm{Ab}$ & $95,00 \mathrm{Aa}$ & $57,50 A$ \\
\hline 500 & ausente & - & - & - & - \\
\hline \multirow{3}{*}{$\begin{array}{l}500 \\
\text { Média }\end{array}$} & presente & - & $30,00 \mathrm{Ab}$ & $100,00 \mathrm{Aa}$ & $65,00 A$ \\
\hline & & - & $25,00 b$ & $97,50 a$ & \\
\hline & \multicolumn{5}{|c|}{$\begin{array}{l}\text { Número de raízes principais } \\
\text { (unidade) }\end{array}$} \\
\hline $\mathbf{0}$ & ausente & 4,27Aa & $2,81 \mathrm{Ab}$ & 4,38Aa & $3,82 A$ \\
\hline $\mathbf{0}$ & presente & - & $1,00 \mathrm{Bb}$ & 2,22Ca & $1,61 C$ \\
\hline 500 & ausente & 4,02Aa & 2,97Ac & $3,50 \mathrm{Bb}$ & $3,49 A$ \\
\hline 500 & presente & - & $1,70 \mathrm{Bb}$ & 3,73Ba & $2,71 B$ \\
\hline \multirow[t]{2}{*}{ Média } & & $4,14 a$ & $2,12 c$ & $3,45 b$ & \\
\hline & \multicolumn{5}{|c|}{$\begin{array}{l}\text { Comprimento maior raiz } \\
\text { (cm) }\end{array}$} \\
\hline $\mathbf{0}$ & ausente & 7,17Аа & $4,18 \mathrm{Ac}$ & 5,61Ab & $5,65 A$ \\
\hline $\mathbf{0}$ & presente & - & 2,08Ca & $2,41 \mathrm{Da}$ & $2,24 C$ \\
\hline 500 & ausente & $7,63 \mathrm{~A}$ & $3,28 \mathrm{Bb}$ & 4,81Ba & $5,24 A$ \\
\hline 500 & presente & - & $2,85 \mathrm{BCb}$ & 3,55Ca & $3,20 B$ \\
\hline Média & & $7,40 a$ & $3,10 c$ & $4,10 b$ & \\
\hline
\end{tabular}


Tabela 17. Comprimento, diâmetro e sobrevivência de enxertia de estacas herbáceas, semi-lenhosas e lenhosas de citrumelo 'Swingle', submetidas a enxertia e imersão em solução com IBA 0 e 500mg L ${ }^{-1}$, 210 dias após transplante (DAT) para sacolas de 4,5L com substrato. Piracicaba, 2004

\begin{tabular}{|c|c|c|c|c|c|c|c|}
\hline Tratamento & Tipo de estaca & Enxerto & $\begin{array}{c}\text { IBA } \\
\left(\mathrm{mg} \mathrm{L}^{-1}\right)\end{array}$ & $\begin{array}{c}\text { Comprimento } \\
30 \mathrm{DAT} \\
\text { (cm) } \\
\end{array}$ & $\begin{array}{c}\text { Comprimento } \\
210 \text { DAT } \\
\text { (cm) }\end{array}$ & $\begin{array}{c}\text { Diâmetro } \\
210 \text { DAT } \\
\text { (mm) }\end{array}$ & $\begin{array}{c}\text { Sobrevivência } \\
\text { enxertia } \\
(\%)\end{array}$ \\
\hline T 1 & herbácea & ausente & 0 & $22,91 \mathrm{~B}$ & $70,00 \mathrm{AB}$ & $6,95 \mathrm{~A}$ & - \\
\hline $\mathbf{T} 2$ & herbácea & ausente & 500 & $23,50 \mathrm{~B}$ & $83,00 \mathrm{~A}$ & $7,21 \mathrm{~A}$ & - \\
\hline T 3 & lenhosa & presente & $\mathbf{0}$ & $12,00 \mathrm{D}$ & $26,67 \mathrm{D}$ & $3,22 \mathrm{C}$ & 66,67 B \\
\hline $\mathbf{T} 4$ & lenhosa & presente & 500 & $14,58 \mathrm{CD}$ & $38,33 \mathrm{CD}$ & 3,35 C & $91,67 \mathrm{~A}$ \\
\hline $\mathbf{T} 5$ & lenhosa & ausente & 0 & $17,17 \mathrm{C}$ & $70,00 \mathrm{AB}$ & $6,37 \mathrm{AB}$ & - \\
\hline T 6 & lenhosa & ausente & 500 & $17,25 \mathrm{C}$ & $62,00 \mathrm{ABC}$ & $5,74 \mathrm{AB}$ & - \\
\hline $\mathbf{T} 7$ & semi & ausente & 0 & $16,58 \mathrm{C}$ & $69,00 \mathrm{AB}$ & $6,93 \mathrm{~A}$ & - \\
\hline T 8 & semi & ausente & 500 & $17,34 \mathrm{C}$ & $68,00 \mathrm{AB}$ & $6,12 \mathrm{AB}$ & - \\
\hline T 9 & semente & presente & - & $58,00 \mathrm{~A}$ & 48,33 BCD & $4,67 \mathrm{BC}$ & $96,00 \mathrm{~A}$ \\
\hline
\end{tabular}

Médias seguidas por letras maiúsculas diferentes em colunas diferem entre si a 5 \% de probabilidade pelo Teste de Tukey. 
Tabela 18. Matéria seca de parte aérea e sistema radicular e volume de sistema radicular de estacas herbáceas, semi-lenhosas e lenhosas de citrumelo 'Swingle', submetidas a enxertia e imersão em solução com IBA 0 e 500mg L ${ }^{-1}$, 210 dias após transplante (DAT) para sacolas de 4,5L com substrato. Piracicaba, 2004

\begin{tabular}{ccccccc}
\hline Tratamento & $\begin{array}{c}\text { Tipo de } \\
\text { estaca }\end{array}$ & Enxerto & $\begin{array}{c}\text { IBA } \\
\left(\mathbf{m g ~ L}^{-\mathbf{1}}\right)\end{array}$ & $\begin{array}{c}\text { Matéria seca } \\
\text { parte aérea } \\
\mathbf{( g )}\end{array}$ & $\begin{array}{c}\text { Matéria seca } \\
\text { sistema radicular } \\
\mathbf{( g )}\end{array}$ & $\begin{array}{c}\text { Volume } \\
\text { sistema radicular } \\
(\mathbf{m L})\end{array}$ \\
\hline T 1 & herbácea & ausente & $\mathbf{0}$ & $17.27 \mathrm{~A}$ & $15.81 \mathrm{~B}$ & $55,00 \mathrm{~A}$ \\
T 2 & herbácea & ausente & $\mathbf{5 0 0}$ & $18.76 \mathrm{~A}$ & $17.32 \mathrm{AB}$ & $60,00 \mathrm{~A}$ \\
T 3 & lenhosa & presente & $\mathbf{0}$ & $6.52 \mathrm{C}$ & $6.58 \mathrm{D}$ & $15,00 \mathrm{C}$ \\
T 4 & lenhosa & presente & $\mathbf{5 0 0}$ & $7.54 \mathrm{C}$ & $7.46 \mathrm{D}$ & $15,00 \mathrm{C}$ \\
T 5 & lenhosa & ausente & $\mathbf{0}$ & $19.34 \mathrm{~A}$ & $12.64 \mathrm{C}$ & $45,00 \mathrm{~B}$ \\
T 6 & lenhosa & ausente & $\mathbf{5 0 0}$ & $19.27 \mathrm{~A}$ & $19.38 \mathrm{~A}$ & $55,00 \mathrm{~A}$ \\
T 7 & semi & ausente & $\mathbf{0}$ & $13.42 \mathrm{~B}$ & $12.21 \mathrm{C}$ & $40,00 \mathrm{~B}$ \\
T 8 & semi & ausente & $\mathbf{5 0 0}$ & $11.01 \mathrm{~B}$ & $13.45 \mathrm{C}$ & $45,00 \mathrm{~B}$ \\
T 9 & semente & presente & - & $11.22 \mathrm{~B}$ & $13.26 \mathrm{C}$ & $50,00 \mathrm{AB}$ \\
\hline
\end{tabular}

Médias seguidas por letras maiúsculas diferentes em colunas diferem entre si a 5\% de probabilidade pelo Teste de Tukey. 
Tabela 19. Custos de produção de mudas obtidas convencionalmente e de mudas e subenxertos obtidos de estacas enraizadas de citrumelo 'Swingle'. Piracicaba, 2005

\begin{tabular}{|c|c|c|c|}
\hline $\begin{array}{l}\text { Custos } \\
\text { Muda Cítrica }^{1}\end{array}$ & $\begin{array}{l}\text { Muda obtida } \\
\text { de semente }\end{array}$ & $\begin{array}{c}\text { Muda obtida } \\
\text { de estaca }\end{array}$ & $\begin{array}{c}\text { Subenxerto } \\
\text { obtido de estaca }\end{array}$ \\
\hline \multicolumn{4}{|l|}{ Operacionais } \\
\hline \multicolumn{4}{|l|}{ Insumos } \\
\hline $\begin{array}{l}\text { Porta-enxerto/ } \\
\text { borbulhas }\end{array}$ & 0,83 & 0,65 & 0,55 \\
\hline Substrato & 0,36 & 0.33 & 0.33 \\
\hline Adubos / Defensivos & 0,32 & 0.30 & 0.30 \\
\hline Materiais & 0,12 & 0.11 & 0.11 \\
\hline Subtotal & 1,64 & 1.39 & 1.29 \\
\hline Mão-de-obra & & & \\
\hline enchimento & 0,39 & 0.36 & 0.36 \\
\hline $\begin{array}{l}\text { Manejo de adubos e } \\
\text { defensivos }\end{array}$ & 0,17 & 0.16 & 0.16 \\
\hline $\begin{array}{l}\text { Desbrota, seleção e } \\
\text { outras operações }\end{array}$ & 0,21 & 0.23 & 0.23 \\
\hline Administração & 0,16 & 0.15 & 0.15 \\
\hline Subtotal & 0,93 & 0.90 & 0.90 \\
\hline Total Operacional & 2,57 & 2.30 & 2.20 \\
\hline $\begin{array}{l}\text { Depreciação + Manutenção } \\
\text { + Certificaçãa + Juros }\end{array}$ & 0,78 & 0.72 & 0.72 \\
\hline Total Custo & 3,35 & $3.63 *$ & 2.92 \\
\hline
\end{tabular}

${ }^{1}$ Valores em R \$/muda.

*Considerando-se descarte médio de 20\% 


\section{CONCLUSÕES}

- Porta-enxertos cítricos semeados diretamente em recipientes de 1,7L atingem ponto ideal para subenxertia no campo a partir de 100 a 150 dias após a semeadura.

- Mudas de laranja 'Pêra' sobre porta-enxerto citrumelo 'Swingle' podem ser satisfatoriamente produzidas utilizando-se interenxertos de laranjas 'Valência' e 'Hamlin' e tangerinas 'Sunki’ e ‘Cleópatra'.

- Estacas herbáceas com um par de folhas, obtidas do terço superior de porta-enxertos com seis meses de idade, são as mais indicadas para fins de enraizamento e multiplicação de citrumelo 'Swingle', constituindo uma boa alternativa para fins de subenxertia no campo. 


\section{REFERÊNCIAS BIBLIOGRÁFICAS}

BASSANEZI, R.B.; YAMAMOTO, P.T.; GIMENES-FERNANDES, N . Progresso dos sintomas de “morte súbita” em pomares de laranjeiras 'Valência' e 'Pêra'. In: CONGRESSO PAULISTA DE FITOPATOLOGIA, 25., Espírito Santo do Pinhal, 2002. Programa e resumos. Espírito Santo do Pinhal: Grupo Paulista de Fitopatologia, 2002. p. 25-42.

BERTLING, I.; LOVATT, C.J. A possible hormonal basis for vigour/dwarfing in commercially important citrus rootstocks. Proceedings of the International Society of Citriculture, v.2, p.745-747b, 1996.

BITTERS, W.P.; COLE, D.A.; MCCARTY, C.C. Effect of budding height on yield and tree size of 'Valencia' orange on two rootstock. Proceedings of the International Society of Citriculture, v.1, p.109-110, 1981a.

BITTERS, W.P.; COLE, D.A.; MCCARTY, C.C. Effect of height and lenght of reciprocal interstock insertion on yield and tree size of 'Valencia' orange. Proceedings of the International Society of Citriculture, v.1, p.110-113, 1981b.

BOWMAN, K.D. Comparison of two citrus bud-forcing methods for rapid propagation of scions on new hybrid citrumelo rootstoks. HortScience, v.34, n.1, p.142-143, 1999. 
CARLOS, E.F. Avaliação de proteínas associadas ao declínio dos citros em plantas interenxertadas. Jaboticabal 1996. 71p. Dissertação (Mestrado)- Faculdade de Ciências Agrárias, Universidade Estadual Paulista “Júlio de Mesquita Filho”.

CARLOS, E.F.; STUCCHI, E.S.; DONADIO, L.C. Porta-enxertos para a citricultura paulista. Boletim Citrícola, n.1, p.17, 1997.

CASTLE, W.S. Citrus root systems: their structure, function, growth, and relationship to tree performance. Proceedings of the International Society of Citriculture, v.90, n.1, p.62-69, 1978.

CASTLE, W.S. Planting density and tree size control in citrus. Florida Agricultural Experiment Station Journal Series, n. 1040, p.30-37, 1981.

CASTLE, W.S.; YOUTSEY, C.O. Root system characteristics of citrus nursery trees. Proceedings of the Florida State for Horticultural Society, v.90, p.39-44, 1977.

CENTRO DE CITRICULTURA SYLVIO MOREIRA. Nova doença já causa prejuízos a pomares de São Paulo e Minas Gerais. Informativo Centro de Citricultura, n.76, p.1-4, 2001.

COORDENADORIA DE DEFESA VEGETAL. Revista eletrônica. www.cda.sp.gov.br. (15 mar. 2005).

FACHINELlO, J.C.; HOFFMANN, A.; NACHTIGAL, J.C. Propagação de plantas frutíferas de clima temperado. Pelotas: UFPEL, 1995. 178p.

FERRI, C.P. Enraizamento de estacas de citros. Revista Brasileira de Fruticultura, v.19, n.1, p.113-121, 1997. 
FIGUEIREDO, J.O. Variedades copa de valor comercial. In: RODRIGUEZ, O. (Ed.). Citricultura brasileira. Campinas: Fundação Cargill, 1991, v.1, p.228-264.

FIORAVANTI, C. Sem segredos: equipe da Alellyx apresenta uma descrição detalhada de um vírus associado à morte súbita dos citros. Pesquisa Fapesp, n.109, p.24-27, mar. 2005.

FNP CONSULTORIA \& COMÉRCIO, AGRIANUAL 2005: anuário da agricultura brasileira. São Paulo, 2005. 520p.

FOX, R.H; PIEKIELEK, W.P.; Mac NEAL, K.M. Using a chlorophyllmeter to predict nitrogen fertilizer needs of winter wheat. Communications in Soil Science and Plant Analysis, v.25, p.171-181, 1994.

FUNDECITRUS. Revista do Fundecitrus, n.121, p.10-11, mar/abr 2004.

FUNDECITRUS. Revista eletrônica www.fundecitrus.com.br. (13 abr. 2003)

FUNDECITRUS. Revista eletrônica www.fundecitrus.com.br. (15 mar. 2005)

GIMENES-FERNANDES, N.; BASSANEZI, R.B. Doença de causa desconhecida afeta pomares cítricos no norte de São Paulo e sul do Triângulo Mineiro. Summa Phytopathologica, v.27, p.93, 2001.

GIRARDI, E. A.; OLIC, F.B.; MOURÃO FILHO, F.A.A.; GRAF, C.C.D. Growth of citrus nursery trees related to the container volume. In: INTERNATIONAL CONGRESS OF CITRUS NURSERYMEN, Ribeirão Preto, 2001. Proceedings. Ribeirão Preto: Estação Experimental de Citricultura de Bebedouro, 2001a. p.316320. 
GIRARDI, E. A.; MOURÃO FILHO, F.A.A.; GRAF, C.C.D. Produção de 'seedlings' de porta-enxertos cítricos em função de doses de fertilizante de liberação lenta e extração do tegumento de sementes (compact disc). In: SIMPÓSIO INTERNACIONAL DE INICIAÇÃO CIENTÍFICA DA USP, 9., Piracicaba, 2001. Resumos. Piracicaba: Universidade de São Paulo, 2001 b.

GOMES, M.P. Mudas em containers: Uma ótima opção. Revista Cutrale, n.1, p.6, 1989.

GOUIN, F.R. Plastic planter bags, advantages and disadvantages. Nursery Business, v.24, n.6, p.63-64,1979.

HARTMANN, H.T.; KESTER, D.E. Plant propagation: principles and pratices. 4.ed. Englewood Cliffs: Prentice Hall, 1983. 727p.

HARTMANN, H.T.; KESTER, D.E.; DAVIES JUNIOR., F.T.; GENEVE, R.L. Plant propagation: principles and practices. 7.ed. New Jersey: Prentice Hall, 2002. 880p.

JESUS JR., W.C. de; BASSANEZI, R.B.; BERGAMIN FILHO, A. Morte súbita dos citros ainda tem origem desconhecida. Visão Agrícola, v.1, n.2, p.34-39, dez. 2004.

KOLLER, O.L.; SOPRANO, E.; COSTA, A.C.Z. de. Avaliação de porta-enxertos para laranjeira 'Hamlin' em Santa Catarina. Revista Ceres, v.47, n.271, p.325-336, 2000 .

KREZDORN, A.H. Interstocks for tree size control in citrus. Proceedings of the Florida State for Horticultural Society, v.91, p.50-52, 1978. 
LABANAUKAS, C.K.; BITTER, W.P. The influence of rootstocks and interstocks on the nutrients levels in 'Valencia' orange leaves. Journal of the American Society for Horticultural Science, v.99, p.32-33, 1974.

LLORENTE, S.; ROMOJARO, F.; UREÑA, R.; ALCARAZ, C.F. Influence of intermediate grafting tecnique on Verna lemon fruit quality. In: INTERNATIONAL COLLOQUIUM FOR THE OPTIMIZATION OF PLANT NUTRITION, 6., Montpelier, 1984. Proceedings. Montpellier: GERDAT, 1984. v.1, p.339-344.

MACCHERONI, W.; ALEGRIA, M.C; GREGGIO, C.C.; PIAZZA, J.P; KAMLA, R.F; ZACHARIAS, P.R.A.; BAR-JOSEPH, M.; KITAJIMA, E.W.; ASSUMPÇÃO, L.C.; CAMAROTTE, G.; CARDOZO, J.; CASAGRANDE, E.C.; FERRARI, F.; FRANCO, S.F.; GIACHETTO, P.F.; GIRASOL, A.; JORDÃO JR, H.; SILVA, V.H.A.; SOUZA, L.C.A.; AGUILAR-VILDOSO, C.I.; ZANCA, A.S.; ARRUDA, P.; KITAJIMA, J.P.; REINACH, F.C.; FERRO, J.A.; SILVA, A.C.R. da Identification and genomic characterization of a new virus (Tymoviridae Family) associated with Citrus Sudden Death Disease. Journal of Virology, v.79, n.5, p.3028-3037, 2005.

MARTÍNEZ-PÉREZ, D. Desenvolvimento, produção e qualidade dos frutos de laranjeiras doces [Citrus sinensis (L.) Osbeck] enxertadas em citrumelo 'Swingle'[Citrus paradise Macf. x Poncirus trifoliata (L.) Raf.]. Jaboticabal, 1999. 178p. Tese (Doutorado) - Faculdade de Ciências Agrárias, Universidade Estadual Paulista “Júlio de Mesquita Filho”.

Mc LEAN, A.P.D. Abnormal bud-union between some sweet oranges and Rough lemon rootstock: evidence that it is caused by a transmissible pathogen. In: CONFERENCE OF THE INTERNATIONAL ORGANIZATION OF CITRUS VIROLOGISTS, 6., Swaziland, 1972. Proceedings. Swaziland:IFAS , 1972. p.203223. 
MORENO, P.; PIQUER, J.; NAVARRO, L.; CARBONELL, E.A.; PINA, J.A.. Ensayos para evitar el decaimento causado por el virus de la Tristeza de los Citricos (CTV) em arboles injertados sobre patron Naranjo Amargo. Investigaciones Agrarias y Producción Vegetal, v.9, n.3, p.465-476, 1994.

MÜLLER, G.W.; NEGRI, J.D.; AGUILAR-VILDOSO, C.I.; MATTOS JÚNIOR, D.; POMPEU JÚNIOR, J.; TEÓFILO SOBRINHO, J.; CARVALHO, S.A.; GIROTTO, L.F.; MACHADO, M.A. Morte súbita dos citros: uma nova doença na citricultura brasileira. Revista Laranja, v. 23, n.2, p.371-386, 2002.

PANZANI, C.R.; PRATES, H.S.; GREVE, A. Sistema de produção de muda certificada de citros no Estado de São Paulo. Revista Laranja, v.15, n.1, p.175-199, 1994.

PASCHAL, M.; CHALFUN, N.N.J.; RAMOS, J.D. Fruticultura comercial: propagação de plantas frutíferas. Lavras: UFLA; FAEPE, 2001. 137p.

PIO, R.; RAMOS, J.D.; GONTIJO, T.C.A.; CARRIJO, E.P.; COELHO, J.H.C.; ALVARES, B.F.; MENDONÇA, V. Enraizamento de estacas dos porta-enxertos de citros 'Fly Dragon'e 'Trifoliata'. Revista Brasileira de Agrociência, v.8, n.3, p.195-198, 2002.

PLATT, R.G.; OPITZ, K.W. Propagation of citrus. In: REUTHER, W. (Ed.). The citrus industry. Riverside: University of California, 1973. v.3, p.1-47.

POMPEU JR, J. Porta-enxertos. In: RODRIGUEZ, O.; VIÉGAS, F.; POMPEU JÚNIOR., J.; AMARO, A.A. Citricultura brasileira. Campinas: Fundação Cargill, 1991. v.1, p.265-280. 
POZZAN, M.; KANASHIRO, M. Custo de muda cítrica em viveiro telado.In: FNP CONSULTORIA \& COMÉRCIO. AGRIANUAL 2004: anuário da agricultura brasileira. São Paulo, 2004, p.250-253.

PRATI, P.; MOURÃO FILHO, F.A.A.; DIAS, C.T.S.; SCARPARE FILHO, J.A. Estaquia semi-lenhosa: um método rápido e alternativo para a produção de mudas de lima ácida ‘Tahiti’. Scientia Agricola, v.56, n.1, p.185-190, 1999.

REZENDE L. P.; AMARAL A.M. do; CARVALHO S.A. de; SOUZA M. Volume de substrato e superfosfato simples na formação do limoeiro 'Cravo' em vasos. I. Efeitos no crescimento vegetativo. Revista Laranja, n.16, p.165-177, 1995.

ROCHA, A.C.; SANDRINI, M.; CARVALHO, S.A. Propagação de três espécies de citros através do enraizamento de estacas verdes. Revista Brasileira de Fruticultura, v.10, n.2, p.31-33, 1988.

SALIBE, A.A. Anormalidades com sintomas semelhantes aqueles das doenças de vírus. In: UNIVERSIDADE ESTADUAL PAULISTA “JÚLIO DE MESQUITA FILHO”. FACULDADE DE CIÊNCIAS MÉDICAS E BIOLÓGICAS. Curso de especialização em citricultura a nível de pós-graduado. Botucatu: UNESP, 1969. 176p.

SAMPAIO, V.R. Behavior of 'Valencia' orange trees grafted on Rangpur lime with interstock of Poncirus trifoliata. In: INTERNATIONAL HORTICULTURAL CONGRESS, 23., Firenze, 1990. Abstracts. Bologna: National Research Council, 1990. p.329.

SAMPAIO, V.R. Efeitos de filtros de Poncirus trifoliata e de alturas de enxertia na laranjeira 'Valencia' enxertada em limão 'Cravo'. Scientia Agricola, v. 50, n.3, p. 360-364, 1993. 
SANTOS, R.F.A. dos; VILLAS-BÔAS, R.M.F.; SALIBE, A.A. Estudos sobre o enraizamento de estacas de citros com aplicação de agentes de efeito hormonal. In: CONGRESSO BRASILEIRO DE FRUTICULTURA, 9., Campinas, 1987. Anais. Campinas: Sociedade Brasileira de Fruticultura, 1987. p.387-393.

SHAKED, A.; COHEN, A.; HAMOU, M.; HASDAI, D. Inarching of Swingle Citrumelo in Israel. HortScience, v.22, n.6, p.1258-1260, 1987.

TEÓFILO SOBRINHO, J. Propagação de citros. In: RODRIGUEZ, O. (Ed). Citricultura Brasileira. Campinas: Fundação Cargill, 1991, v.1, p.281-301.

TERSI, F.E.A. Quanto custa a subenxertia em pomar cítrico. In: FNP CONSULTORIA \& COMÉRCIO. AGRIANUAL 2004: anuário da agricultura brasileira. São Paulo, 2004. p.254-256.

TERSI, F.E.A.; OJEDA, R.; GRAVENA, S. Técnica preventiva para escape da doença Morte Súbita dos Citros. In: CURSO TEÓRICO-PRÁTICO DE SUBENXERTIA. Jaboticabal, 2003. Apostila. Jaboticabal: Gravena ManEcol Edições, 2003.

VALENTE, J.P. Influência de diferentes interenxertos na laranjeira 'Pêra' sobre limoeiro 'Cravo'. Jaboticabal, 1993. 77p. Tese (Doutorado) - Faculdade de Ciências Agrárias, Universidade Estadual Paulista “Júlio de Mesquita Filho”.

VALERO, J.B.F. Interacciones entre el injerto y el patron em los agrios. Ministerio de Agricultura, pesca y Alimentacion, Madrid, ESPANA, Hojas Divulgadoras, n. 9. p.1-20, 1984. 
VILLAS-BÔAS, R.M.F.; SANTOS, R.F.A. dos; SALIBE, A.A. Enraizamento de estacas de diferentes espécies de citros. In: CONGRESSO BRASILEIRO DE FRUTICULTURA, 9., Campinas, 1987. Anais. Campinas: Sociedade Brasileira de Fruticultura, 1987.v.1, p.367-373.

VIVECITRUS. Informativo Vivecitrus, v. 4, n.14, p.4, jun. 2004.

WILLIAMSON, J.G.; MAUST, B.E. Rootstock shoot contributions to scion growth of containerized citrus nursery trees. Proceedings of the Florida State for Horticultural Society , v.106, p.52-54, 1993.

WILLIAMSON, J.G.; CASTLE, W.S.; KOCH, K.E. Growth and 14C-photosynthate allocation in citrus nursery trees subjected to one of three bud-forcing methods. Journal of the American Society for Horticultural Science, v.117, n.1, p.37-40, 1992.

WUTSCHER, H.K. Uso apropriado de las combinaciones injerto/patron en citricos en el tropico. Proceedings of the Interamerican Society of Tropical Horticulture, v.42, p.166-172, 1998. 